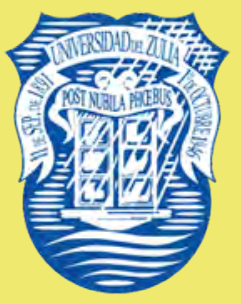

UNIVERSIDAD DEL ZULIA

REVISTA CIENTÍFICA

FACULTAD DE CIENCIAS VETERINARIAS DIVISIÓN DE INVESTIGACIÓN

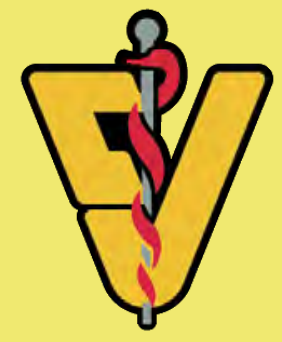

MARACAIBO, ESTADO ZULIA, VENEZUELA

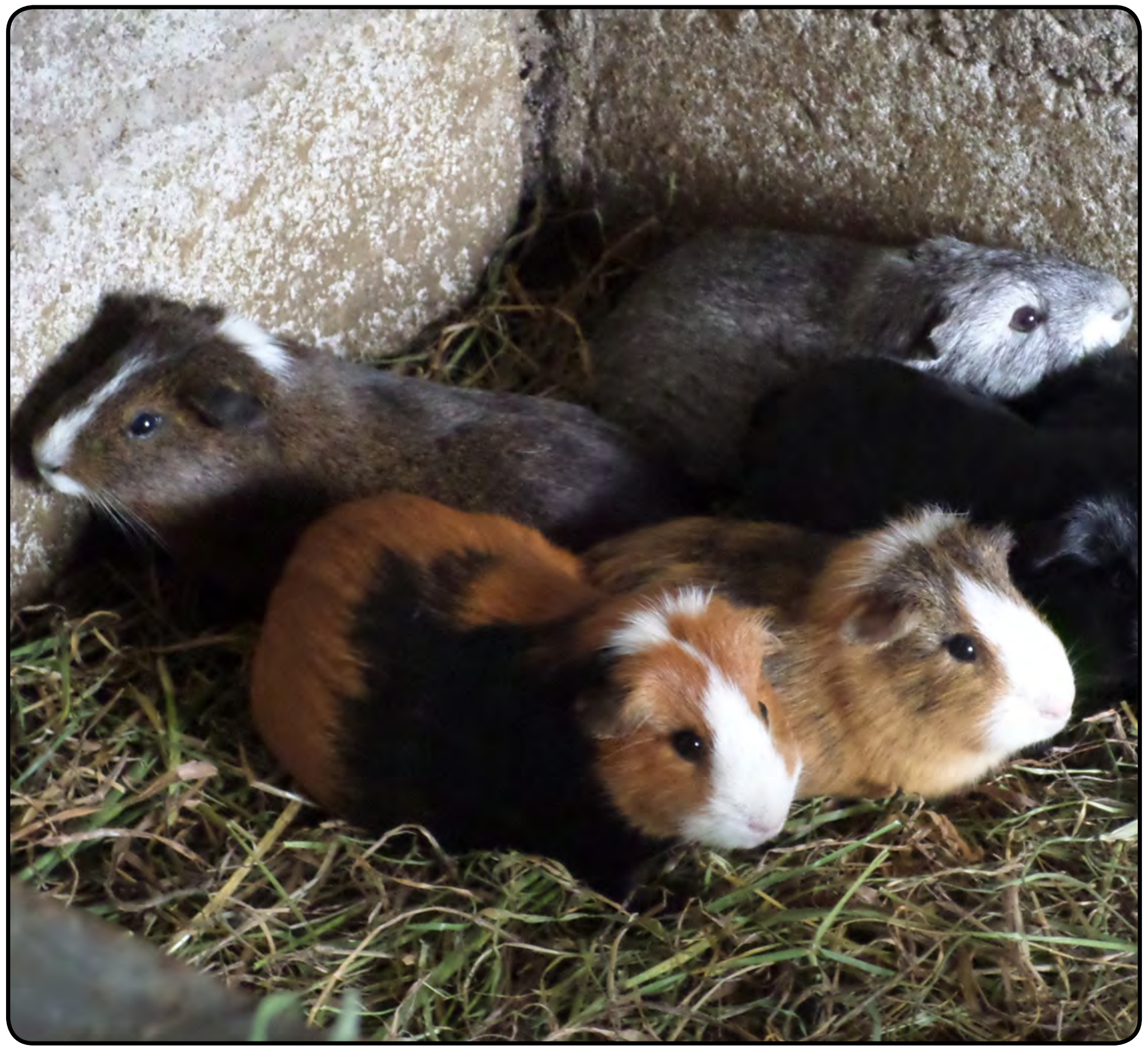

Vol. XXXI (2) 2021 


\section{REVISTA CIENTÍFICA}

\author{
Fundada en 1990 \\ Universidad del Zulia \\ Facultad de Ciencias Veterinarias \\ Maracaibo, Estado Zulia, Venezuela \\ Vol.XXXI (2) 2021

\section{MIEMBROS FUNDADORES} \\ José Faría R. (†) \\ Mario Pérez $B$. \\ Manuel Alvarado M. \\ DIRECTOR FUNDADOR \\ Rafael César Reátegui Cárdenas ( $†$ ) \\ EDITOR JEFE \\ Mario Pérez Barrientos \\ EDITOR ASOCIADO \\ Edison Pascal-Bello \\ Portada:
}

Morfometria y faneroptica de subpoblaciones de cobayos nativos (Cavia porcellus) del altiplano sur ecuatoriano

(Págs. 71 - 79)

SECRETARIA EJECUTIVA

Marilyn Del V. Añez Davila

DISEÑO GRÁFICO

Oscar De La Rosa

La edición de esta revista ha sido auspiciada por el Vicerrectorado Académico LUZ, el Sistema de Servicios Bibliotecarios y de Información (Serbiluz) y Consejo de Desarrollo Científico y Humanístico de LUZ (CONDES)

\section{SE AGRADECE CANJE EXCHANGE DESIRED}

DIRECCIÓN:

Revista Científica

Universidad del Zulia, Facultad de Ciencias Veterinarias Núcleo Agropecuario Ciudad Universitaria

Apdo.15252, Maracaibo 4005-A

Estado Zulia-Venezuela

Telf.-Fax:58-261-4126158

E-mail:revistafcv@gmail.com

http://produccioncientificaluz.org/index.php/cientifica

El índice acumulado anual aparecerá en el último número de cada volumen.

Esta revista fue editada en formato digital y publicada en Junio de 2021, por

La Facultad de Ciencias Veterinarias de La Universidad del Zulia

Maracaibo - Venezuela.
UNIVERSIDAD DEL ZULIA

\section{EDITORES ASOCIADOS}

Dr. Dionel García Bracho. Universidad del Zulia, Maracaibo, Venezuela

Dr. Willian Mejía Silva. Universidad del Zulia, Maracaibo, Venezuela

Dr. Armando Quintero Moreno. Universidad del Zulia, Maracaibo, Venezuela

Dr. José Atilio Aranguren Méndez. Universidad del Zulia, Maracaibo, Venezuela

Dra. María Elena Peña. Universidad del Zulia, Maracaibo, Venezuela

Dra. Julia Velasco Fuenmayor. Universidad del Zulia, Maracaibo, Venezuela

Dr. Wilfido Briñez Zambrano. Universidad del Zulia, Maracaibo, Venezuela

Dr. José Manuel Rodríguez. Universidad del Zulia, Maracaibo, Venezuela

Dr. Francisco Angulo Cubillán. UTE. Quito. Ecuador

Dra. Libia Guzmán. Universidad del Tolima, Colombia

Dr. Hugo Hernández Fonseca. St. George's University, Granada

Dr. Aureliano Hernández. Universidad Nacional de Colombia, Colombia

Dr. José María Alunda. Universidad Complutense de Madrid, España

Dr. Andrés Ortega Ojeda. UTE. Quito, Ecuador

\section{COMITÉ DE ASESORES}

Pedro M. Aso. Universidad Simón Bolívar, Caracas, Venezuela

Alfredo Coronado. Universidad Centro-Occidental Lisandro Alvarado, Barquisimeto, Venezuela

Roy D. Meléndez. Universidad Centro-Occidental Lisandro Alvarado, Barquisimeto, Venezuela

Héctor Soto Castellanos. Universidad Nacional Experimental Simón Rodríguez, Caracas, Venezuela

Antonio Bretaña. Universidad Nacional Experimental Simón Rodríguez, Caracas, Venezuela

Marc Desquesnes. CIRAD-EMVT, Burkina Faso, West Africa

Edmundo Grisard. Universidade Federal de Santa Catarina, Brasil

Alexis Rodríguez Acosta. Universidad Central de Venezuela, Caracas, Venezuela

Elías Sogbe Martinís. Universidad Central de Venezuela, Maracay, Venezuela

Andrés Soyano. Instituto Venezolano de Investigaciones Científicas (IVIC), Los Teques, Venezuela

Rafael Román Bravo. Universidad del Zulia, Maracaibo, Venezuela

Enrique Márquez Salas. Universidad del Zulia, Maracaibo, Venezuela

Nelson Huerta Leidenz. Universidad del Zulia, Maracaibo, Venezuela

Eleazar Soto Belloso. Universidad del Zulia, Maracaibo, Venezuela

José Luis Ramírez. Universidad de Oriente, Maturín, Venezuela

\footnotetext{
La revista no se hace responsable de los conceptos emitidos por sus autores

Prohibida la reproducción total o parcial del contenido de esta Revista

(C) REVISTA CIENTÍFICA, 2018

(c) FCV, Universidad del Zulia

Revista impresa ISSN 0798-2259 Depósito Legal: pp $199102 Z U 46$
}

Revista electrónica ISSN electrónico: 2477-944X Depósito Legal: ppi $201502 Z U 4665$ 


\section{FACULTAD DE CIENCIAS VETERINARIAS \\ DIVISIÓN DE INVESTIGACIÓN}

\section{REVISTA CIENTÍFICA}

\section{REVISTA INTERNACIONAL ARBITRADA DEDICADA A LA DIVULGACIÓN DE INVESTIGACIONES ORIGINALES EN EL ÁREA AGROPECUARIA}

Vol. XXXI (2) 2021

MARACAIBO, ESTADO ZULIA, VENEZUELA

Indizada y registrada en:

Institute for Scientific Information (ISI): Research Alert ${ }^{8}$ y Focus on: Veterinary Science \& MedicineTM

Science Citation Index (SCIExpanded)

RevicyhLUZ. Revistas Científicas y Humanísticas de LUZ (URL: http://produccioncientificaluz.org/revicyhluz/)

SWETS Blackwell Database

ELSEVIER Extended Science Direct Navigator Database

Ulrich's Periodicals International Directory

Veterinary Bulletin

Index Veterinarius

CAB Abstracts Database - UK

Base de Datos Wildlife \& Ecology Studies Worldwide (EBSCO Publishing Inc.)

Base de Datos de Revistas Venezolanas de Ciencia y Tecnología (REVENCYT)

Registro de Publicaciones Científicas y Tecnológicas Venezolanas del FONACIT - MCT

Asociación de Editores de Revistas Biomédicas Venezolanas (ASEREME)

Asociación Venezolana de Editores de Publicaciones de las Ciencias del Agro (AVEPAGRO)

LATINDEX

Base de Datos "Informe Académico" (Thomson-Gale) USA

Base de Datos LILACS (Literatura Latinoamericana de Ciencias de la Salud)

Base de Datos LIVECS (Literatura Venezolana en Ciencias de la Salud)

Scielo Venezuela (www.scielo.org.ve)

Red de Revistas Científicas de América Latina y el Caribe, España y Portugal (Redalyc): http://redalyc.uaemex.mx/ Sociedad Iberoamericana de Información Científica (SIIC Data Bases), siicsalud. www.siicsalud.com

Citefactor Journals Citefactor.org. Director Indexing of International Research Journals 


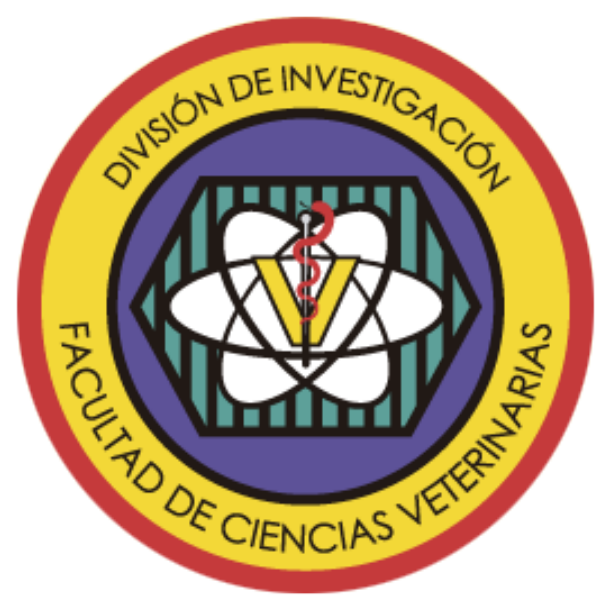

REVISTA CIENTÍFICA, es una revista internacional que representa el órgano científico de la Facultad de Ciencias Veterinarias de la Universidad del Zulia, Maracaibo, Estado Zulia, Venezuela. La misión es publicar la mejor literatura científica tropical y subtropical relacionada a las áreas de las ciencias veterinarias, producción animal, salud pública y tecnología de alimentos de origen animal, así como, literatura científica generada en zonas templadas, pero con aplicabilidad tropical. Todos los trabajos recibidos deben seguir el formato que se presenta en las instrucciones para autores y pasar por un proceso de arbitraje anónimo.

La revista publica cuatro números al año.

Toda correspondencia debe ser enviada a: Editor Jefe REVISTA CIENTÍFICA Facultad de Ciencias Veterinarias Universidad del Zulia. Apartado 15252. Maracaibo 4005-A, Estado Zulia, Venezuela Teléfono-Fax: (58-0261) 4126158. http://produccioncientifica.luz.edu.ve http: //www.fcv.luz.edu.ve
REVISTA CIENTÍFICA, is an international journal representing the scientific organ of the Faculty of Veterinary Sciences at the University of Zulia, Maracaibo, Zulia State, Venezuela. The aim is publishing the best tropical and subtropical scientific literature related to the fields of veterinary clinical sciences, animal production, public health, food sciences and technology of animal products as well as scientific literature generated in temperate zones but with tropical applicability. All the submitted manuscripts must follow the established editorial guidelines and go through an anonymous peer review process.

The journal publishes four issues a year.

All mail must be sent to:

Editor in Chief REVISTA CIENTÍFICA

Facultad de Ciencias Veterinarias

Universidad del Zulia. Apartado 15252.

Maracaibo 4005-A, Estado Zulia, Venezuela

Teléfono-Fax: (58-0261) 4126158.

http://produccioncientifica.luz.edu.ve

http: //www.fcv.luz.edu.ve 


\section{Ziepubfica B̧olivariana de Desenejuefa Eltiversidado del Bulia Consejo 巳̂tniversitario}

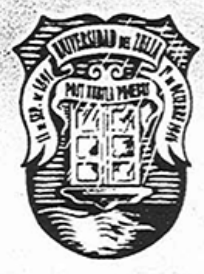

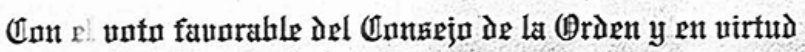
i.: In estahlerìn er el renlamento respertiun, ranftere la

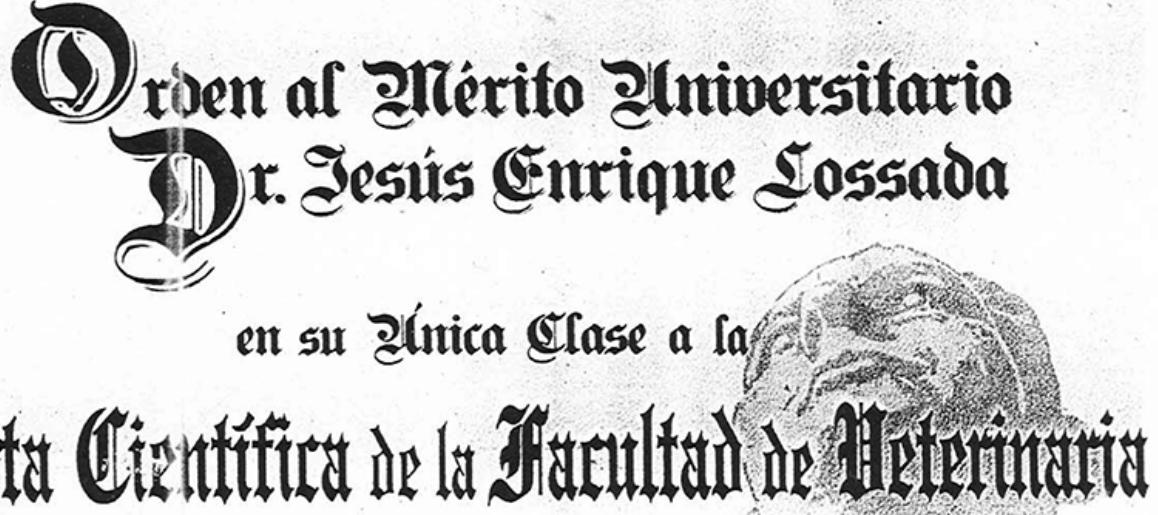

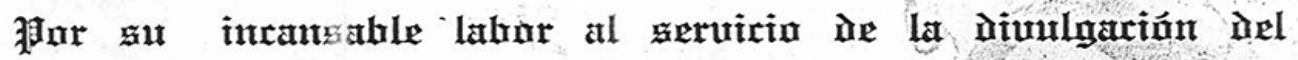

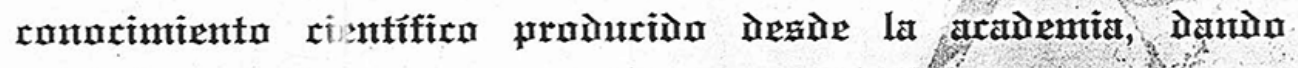

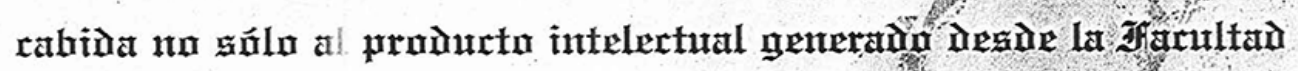

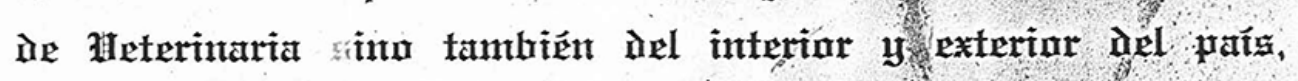

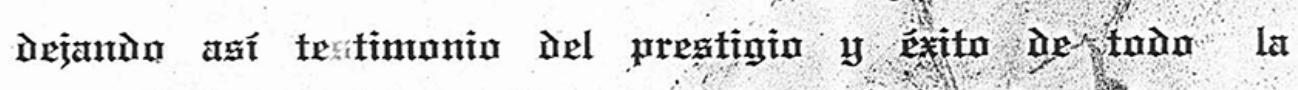

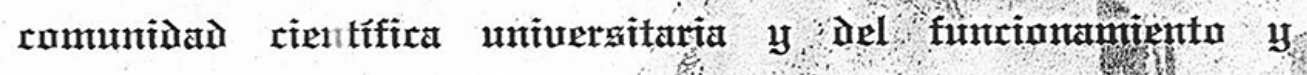

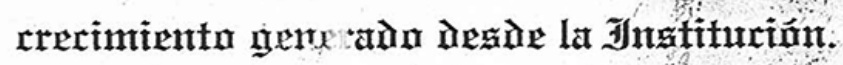

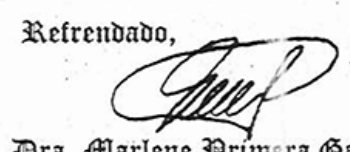

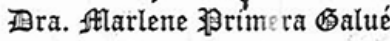
Secretari
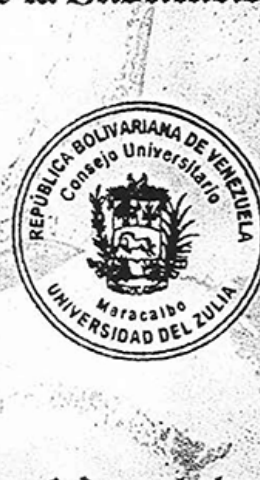

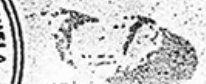

Int. Torge 3 alentia 3 iñũa Ziector-3igresídente

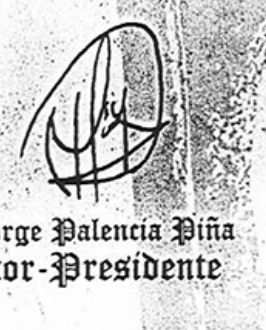




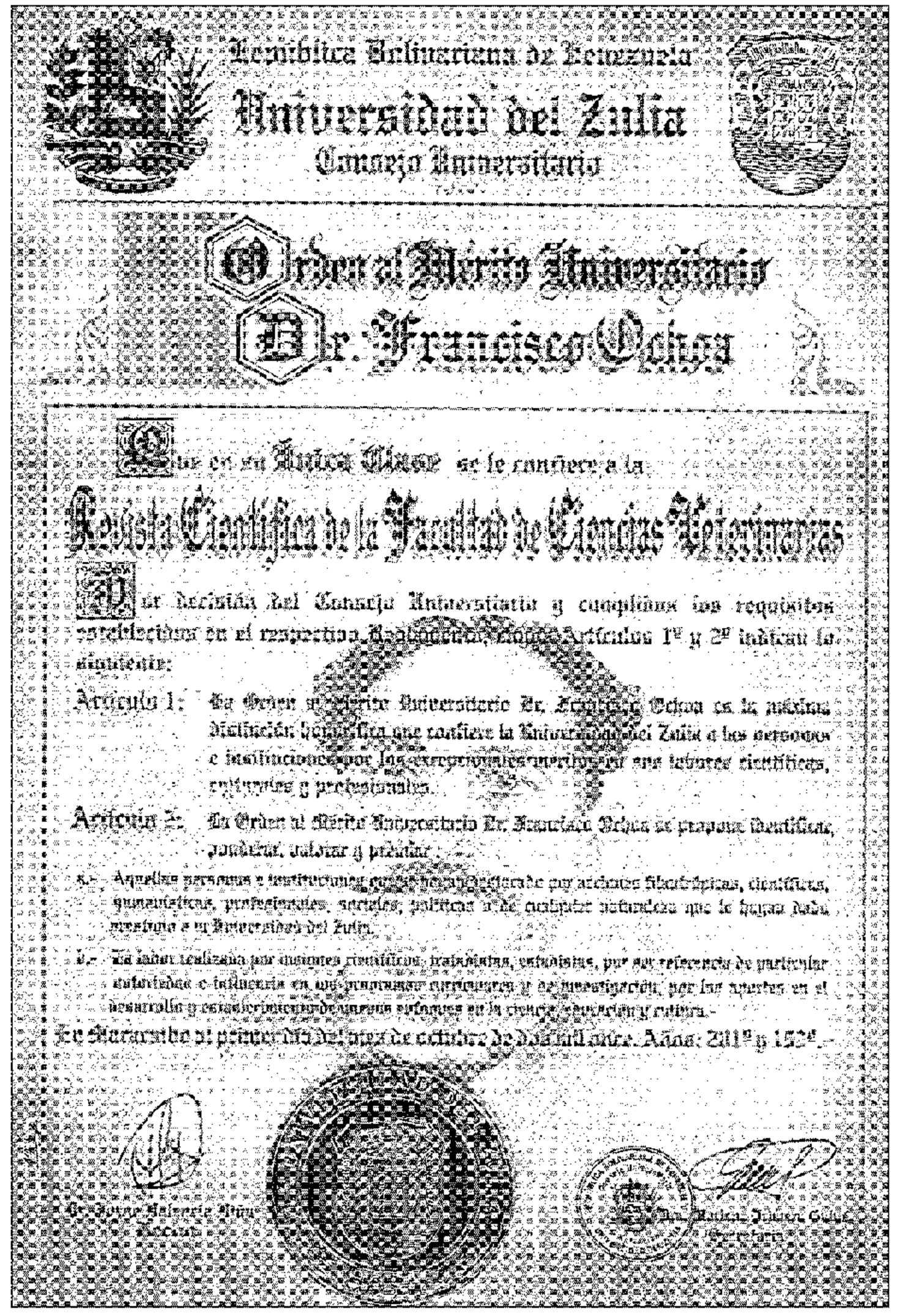




\section{REVISTA CIENTÍFICA}

\section{REVISTA INTERNACIONAL ARBITRADA DEDICADA A LA DIVULGACIÓN \\ DE INVESTIGACIONES ORIGINALES EN EL ÁREA AGROPECUARIA}

Vol. XXXI (2)

EDITORIAL

Salud Pública Veterinaria / Veterinary Public Health

Detección de anticuerpos de Brucella spp. en mataderos del estado Bolívar y Soledad, municipio Independencia, estado Anzoátegui, Venezuela, 2006

Screening of antibodies to Brucella spp. in slaughterhouses of the Bolívar state and Soledad, Independencia Municipality, Anzoategui state, Venezuela, 2006

Julman Rosiris Cermeño y Ricardo De Grazia.

Producción Animal / Animal Production

Fattening performance and carcass traits of implanted and supplemented grassfed bulls

Desempeño en la ceba a pastoreo y rasgos de la canal de toros implantados y suplementados

Nelson Huerta-Leidenz, Nancy Jerez-Timaure, Susmira Godoy, Carlos Rodriguez-Matos y Omar Araujo-Febres ......

Comportamiento animal y composición botánica de la dieta de ovinos apacentando estrella africana (Cynodon plectostachyus (L.) Pers.) en monocultivo y asociada con Leucaena leucocephala (Lam.) de Wit. y Guazuma ulmifolia (Lam.)

Animal behavior and botanical composition of the diet of the african ovine star (Cynodon plectostachyus (L) Pers.) in monoculture and associated with Leucaena leucocephala (Lam.) de Wit. and Guazuma ulmifolia (Lam.)

René Pinto-Ruiz, Angélica Anahí Pérez-Díaz, David Hernández-Sánchez, Francisco Guevara-Hernandez, Gerardo Uriel-Trujillo y Pedro Cadena-Iñiguez.

Morfometria y faneroptica de subpoblaciones de cobayos (Cavia porcellus) nativos del altiplano sur ecuatoriano Morphometric and faneroptic characterization of sub populations native cobayos (Cavia porcellus) of the south equatorian highland

Cornelio Rosales-Jaramillo, Rafael Róman-Bravo y José Aranguren-Méndez. 


\title{
No es la más fuerte de las especies la que sobrevive y tampoco las más inteligente. Sobrevive aquella que más se adapta al cambio
}

\author{
Charles Darwin
}

Desde la academia se nos ha enseñado a pensar y utilizar la observación de los hechos como fuente de investigación para la producción del conocimiento y saberes. Es por ello que al analizar la compleja situación universitaria, y en particular la de nuestra estimada Facultad de Ciencias Veterinarias de La Universidad del Zulia, se hace imperioso evaluar los posibles escenarios de acción... todos ellos con una meta en común... permanecer activos como referentes en el área de las Ciencias Veterinarias, tanto en la producción y divulgación del conocimiento científico a través de la investigación científica, así como en la formación de profesionales altamente capacitados, y con alto sentido de empatía y responsabilidad con el entorno que le corresponda interactuar.

La confusa actualidad nos invita, y mas que eso, nos obliga a repensar seriamente sobre el hecho de no pretender traer lo que, en el pasado, conformo nuestra zona de confort, a un presente y futuro que luce diametralmente distinto... ¿Qué hacer entonces?

Es innegable que las diferentes condiciones actuales del país y las que se vislumbran, en el futuro inmediato, no permiten mantener la estructura de dependencia financiera del Estado que ha caracterizado, hasta este momento, las instituciones universitarias en el país. De allí que, si solo se espera que la respuesta a nuestras dificultades actuales se origine de las fuentes tradicionales de aportación de recursos, se dejara la posible solución a fuerzas alejadas de la propia capacidad decisoria de la comunidad universitaria y se mantendrá una dependencia no sana, como se ha demostrado hasta ahora.

Por otro lado, si se ignora el carácter sistémico de la Universidad al momento de identificar soluciones por medios y acciones, que hasta ahora no han reflejado tener la efectividad que requiere las distintas funciones universitarias, entonces, se estará sumando razones al agente que ocasiona y es mayoritariamente corresponsable de la situación actual.

En tal sentido, es responsabilidad de todos y de cada uno, en lo individual, asumir que todo cambio viene casado con un sin número de oportunidades, muchas de ellas ocultas. Lo que lleva a pensar en una nueva forma de ver, hacer y concebir nuestra actuación como universitarios. Hablar de cambio, generalmente, causa una sensación de vértigo que resulta factor común en diferentes situaciones... algunas veces ese cambio viene impulsado por factores externos que pueden ser de naturaleza poco agradable para quien será sujeto de modificación.

Existen estructuras universitarias que requiere de un cambio planificado, estudiado y evaluado a la luz de alcanzar los mejores resultados, y en otras de sus estructuras organizativas se habla de transformación que permita hacer más efectivas las dependencias universitarias... ambos, tanto el cambio como la transformación, ocasionarán que el funcionamiento de las universidades atienda a su viabilidad real y acorde con los escenarios actuales y no a una propuesta académica, que en sus inicios de creación fue conveniente, pero que requiere de revisión y adecuación.

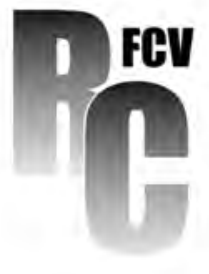


De allí que se debe asumir varias acciones que aborden, sin ser excluyentes de las que no se tiene gobernabilidad, el cambio y transformación que se requiere, y entre las cuales se pudiera mencionar, en primer lugar, la revisión y análisis interno de las causas que han llevado a la situación actual y que son responsabilidad de los universitarios. Solo será posible cambiar lo que está bajo nuestra influencia y responsabilidad. En segundo lugar, la revisión exhaustiva de las estrategias de funcionamiento universitario desde las modalidades de interactuar con los estudiantes hasta las posibles fuentes alternas de financiamiento externo. En tercer lugar, el diseño y puesta en marcha de un sistema de evaluación periódica de los procesos universitarios y los resultados alcanzados en esos procesos y, sobre todo, de la actuación del talento humano que conforma su plantel docente, de investigación y de gestión universitaria.

La cantidad y calidad de conocimiento generado en el área de las Ciencias del ser y el saber relacionadas con la Producción de Alimentos de origen animal, la Salud Publica y la Salud Animal es extensa, variada y de impacto relevante. En el país y en los últimos tiempos, la generación de conocimiento y saberes a través de la investigación ha sido fracturada fuertemente. De todos es conocido el origen de esa situación y sus consecuencias. Hay cientos de circunstancias que requieren de investigación científica que aporte el saber necesario para entenderlas y manejarlas, y cada situación está relacionada con un conjunto de sectores productivos y/o individuos necesitados del resultado de esa investigación. Por lo que el trabajo de creatividad deberá ser dirigido a fomentar y formular coaliciones vitales con organizaciones e instituciones de carácter públicas y privadas, de forma tal que ambas partes obtengan, no solo, la posibilidad de beneficios, sino también de alcanzar el crecimiento esperado y la permanencia en el sector al cual pertenezca.

La luz no permanece inmóvil en el lugar donde se encuentra, sino que, de millonésima en millonésima de segundo, se produce nueva luz... La Facultad de Ciencias Veterinarias, y en particular la Revista Científica de la facultad, permanecen empeñadas en buscar las mejores vías para cumplir con la responsabilidad que les fuera asignada y que representa su aporte al bienestar del país y sus habitantes, basado en el estudio, la discusión y discernimiento hacia un Conocimiento y una Conciencia colectiva repletos de responsabilidad, coherencia e identidad universitaria.

Es la Universidad quien acompaña a la sociedad y basa su actuación en la búsqueda y consecución de la movilidad de esa sociedad hacia estándares de bienestar individuales que al ser sumados se convierten en colectividad.

A pesar de todo lo aparente, es mucho lo que aún se puede hacer y esa es una responsabilidad ineludible que se coloca en nuestras manos.

Sin olvidar... Post Nubila Phoebus ... después de las nubes viene el Sol

Dra. Maria Elena Peña-Marcano

Profesora Titular

Catedra Agronegocios

Facultad de Ciencias Veterinarias

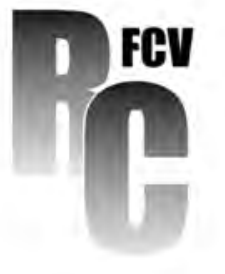




\title{
Detección de anticuerpos de Brucella spp. en mataderos del estado Bolívar y Soledad, municipio Independencia, estado Anzoátegui, Venezuela, 2006
}

\author{
Screening of antibodies to Brucella spp. in slaughterhouses of the Bolívar state and \\ Soledad, Independencia Municipality, Anzoategui state, Venezuela, 2006
}

\author{
Julman Rosiris Cermeño* y Ricardo De Grazia \\ Departamento de Parasitología y Microbiología, Escuela de Ciencias de la Salud "Dr. Francisco Battistini Casalta", \\ Universidad de Oriente, Núcleo Bolívar. Ciudad Bolívar. Venezuela. *Correo electrónico: jcerme30@gmail.com
}

\begin{abstract}
RESUMEN
El objetivo de este estudio fue determinar la seroprevalencia humana y bovina de anticuerpos contra Brucella spp. en mataderos del estado Bolívar y Soledad, municipio Independencia, estado Anzoátegui, Venezuela. Para ello, se realizó un estudio prospectivo y transversal. Previo permiso por escrito de autoridades competentes y consentimiento informado de los trabajadores, se seleccionaron 7 mataderos. Se registraron datos de interés epidemiológico y clínico. Se extrajo sangre por venopunción de personas y bovinos. La demostración de anticuerpos contra Brucella spp. se realizó mediante la prueba DRG $®$ Brucella IgM ELISA en humanos y ELISA competitiva, Brucella-Ab C-ELISA de SVANOVIR ${ }^{\circledR}$, en animales. Se evaluaron 462 sueros: 159 de trabajadores y 303 de bovinos. La prevalencia de infección en humanos fue 5,6 \% y de bovinos $11,2 \%$; el mayor porcentaje se obtuvo en el grupo de los trabajadores con edades entre 21 y 30 años $(a)(P=0,15)$ y de sexo masculino $(P=0,34)$. Siendo más frecuente en el personal que tenía menos de $10 \mathrm{a}$ con riesgo ocupacional (66,6 \%); correspondiendo a la ocupación de matarife y despostador el mayor número de casos. El 55,6 \% de los trabajadores consumían lácteos sin pasteurizar. Las manifestaciones clínicas fueron inespecíficas: artralgias, cefalea y sudoración nocturna $(P>0,05)$. Se demuestra que la mayoría de trabajadores de los mataderos evaluados del estado Bolívar y Soledad, municipio Independencia del estado Anzoátegui, están expuestos a múltiples factores de riesgo para contraer brucelosis, sin embargo, la seroprevalencia de anticuerpos de Brucella spp. en ellos fue baja (5,6 \%) aunque elevada entre los bovinos estudiados (11,2\%).
\end{abstract}

Palabras clave: Bovinos; brucelosis; seroprevalencia

\begin{abstract}
The aim of this study was to determine the seroprevalence of human and bovine antibodies to Brucella spp in Bolivar State slaughterhouses and Soledad, Independencia Municipality, Anzoategui State, Venezuela. To this end, it was conducted to a prospective, cross study. Prior written consent of workers and permission of authorities, seven slaughterhouses were selected. Data were recorded epidemiological and clinical interest. Blood was drawn by venipuncture from subjects and cattle. Demonstration of Brucella spp. antibodies was performed IgM ELISA DRG ${ }^{\circledR}$ Brucella in humans and competitive ELISA, Brucella Ab C-ELISA SVANOVIR $\AA$, in animals. Four hundred sixty two sera were evaluated: 159 workers and 303 cattle. The prevalence of human infection was $5.6 \%$ and $11.2 \%$ of cattle; the highest percentage was obtained in the group of workers aged between 21 and 30 years $(y r)$ old $(P=0.15)$ and male $(P=0.34)$. Being more common in people who were younger than $10 \mathrm{yr}$ with occupational risk $(66.6 \%)$, corresponding to the occupation of butcher and stripper the largest number of cases. The $55.6 \%$ of workers consumed unpasteurized dairy. Clinical manifestations were nonspecific: arthralgia, headache and night sweats $(P>0.05)$. It was showed that most of the studied slaughterhouse workers in Bolivar State and Soledad, Independencia Municipality of Anzoátegui State, are exposed to multiple risk factors for acquiring brucellosis, however, the seroprevalence of antibodies to Brucella spp. in them was low (5.6\%) but higher among the studied cattle (11.2 \%).
\end{abstract}

Key words: Cattle; brucellosis; seroprevalence 


\section{INTRODUCCIÓN}

La brucelosis es una de las zoonosis desatendida más común en todo el mundo; transmitida al hombre por diversos animales: ganado bovino (Bos taurus), ovino (Ovis orientalis aries), caprino (Capra aegagrus hircus), porcino (Sus scrofa domesticus), camellos (Camelus), búfalos (Bubalus bubalis), entre otros [15]. Afecta tanto a los países desarrollados y en desarrollo [23, 26]. La enfermedad es frecuente en la región mediterránea, oeste de Asia, África y América Latina [2, 15, 26].

La infección por Brucella spp. se presenta como consecuencia de la exposición, contacto con animales infectados (tejidos, sangre, orina, heces, secreciones vaginales), y/o algunos de sus derivados (leche y de productos lácteos no pasteurizados), o por la transmisión aérea; en consecuencia los más afectados, son los trabajadores agropecuarios y de mataderos, ya que tienen un alto índice de cortaduras, exposición a la sangre y/o linfa de animales recién muertos, por lo que se ha considerado como una enfermedad ocupacional [8, 15, 24].

Las especies más comunes que afectan al ganado y a los humanos son: $B$. abortus, $B$. suis y $B$. melitensis, que infectan preferencialmente (pero no exclusivamente) al ganado, cerdos y pequeños rumiantes, respectivamente. Otras especies de Brucella incluyen B. ovis (ovejas), B. canis (perros), B. neotomae (roedores), B. microti (topillos), B. pinnipedialis (pinnípedos), B. ceti (cetáceos), B. papionis (babuinos), B. vulpis (zorros) y B. inopinata [36].

En los países en desarrollo donde la brucelosis es endémica, conocer los datos de referencia sobre la prevalencia de Brucella spp. empleando las instalaciones de los mataderos, son importantes [22]; ya que se han asociado las exposiciones ocupacionales a la infección con este microorganismo, particularmente entre los trabajadores [12].

En Venezuela, como en muchos países de Latinoamérica, la brucelosis es una enfermedad que causa importantes pérdidas económicas, especialmente en el ganado bovino, y constituye un grave problema de salud pública ya que representa una amenaza para quienes producen, distribuyen y consumen productos lácteos sin pasteurizar [7]. La brucelosis bovina en Venezuela tiene índices bajos según la cifras oficiales, están entre 0,8 a $14 \%$ [35]. Actualmente la vigilancia epidemiológica de brucelosis bovina en el país consiste en la recolección de la información de las actividades que ejecutan los médicos veterinarios en ejercicio libre, las cuales se procesan a nivel de las oficinas sanitarias locales [28, 35]. La especie predominante en el país es la $B$. abortus, tanto en humanos como en animales, produciendo en la población bovina altas tasas de abortos en hembras e infertilidad en machos, siendo transmisible a humanos expuestos ocupacionalmente [35].

En la actualidad se requieren de estudios clínicos y epidemiológicos (humano y animal) en los diferentes Estados del país para conocer la verdadera prevalencia e incidencia de la brucelosis y su impacto socio-económico. En el estado Bolívar, se desconoce la situación actual de la brucelosis humana y bovina; por ello, se planteó el presente estudio con la finalidad de determinar la seroprevalencia de Brucella spp. en los trabajadores de los mataderos y en el ganado bovino del estado Bolívar y Soledad, municipio Independencia del Edo. Anzoátegui, cuyo matadero suplía las funciones del municipio Angostura del Orinoco, del estado Bolívar, Venezuela.

\section{MATERIALES Y MÉTODOS}

Se realizó un estudio descriptivo, transversal realizado en forma prospectiva.

El estado Bolívar tiene 11 Municipios y posee 9 mataderos en total, ubicados en los municipios: Angostura del Orinoco (antes Heres), Caroní, Piar, Padre Pedro Chien, Cedeño, Sifontes, Roscio, El Callao y Gran Sabana. El matadero del municipio Angostura del Orinoco no estaba en funcionamiento en el momento del estudio, por tal motivo el Matadero Municipal de Soledad, municipio Independencia del estado Anzoátegui, suplía el área de influencia del municipio Angostura del Orinoco del estado Bolívar (100 \%), motivo por el cual se incluyó este último matadero.

Se seleccionaron 7 mataderos, previo permiso de los dueños del ganado y autoridades competentes; además, del consentimiento voluntario de los trabajadores para realizar el estudio; se respetaron los principios éticos para la investigación médica en seres humanos, siguiendo los lineamientos de la Declaración de Helsinki [3]. Este estudio fue aprobado por la Comisión de Tesis de Grado de la Universidad de Oriente, Venezuela, quien revisa los aspectos éticos y metodológicos de la investigación.

\section{Población y muestra humana}

De un total de 209 trabajadores, se evaluaron 159 quienes aceptaron participar en forma voluntaria en el estudio, y que constituían el $76,1 \%$ del total de los trabajadores de los mataderos incluidos: $28(80 \%)$ trabajadores del matadero municipal de Soledad; $36(55,4 \%)$ trabajadores del matadero Maloca C.A., San Félix; 28 (80 \%) trabajadores del matadero municipal de Upata; 18 (90 \%) trabajadores de la sala de matanza municipal de El Callao; 20 (90,9\%) trabajadores de la sala de matanza municipal de Guasipati; 12 (80\%) trabajadores de la sala de matanza municipal de Tumeremo; y 17 (100\%) trabajadores de la sala de matanza municipal de El Palmar.

Los datos de identificación personal, epidemiológicos y manifestaciones clínicas fueron recolectados de manera independiente en una ficha individual diseñada para tal fin.

De cada individuo se obtuvo una muestra sanguínea de la vena cubital (5 - 6 mililitros ( $\mathrm{mL}$ ) en tubos estériles al vacío (Vacutainer ${ }^{\circledR}$ ). Media hora después de su obtención, las muestras fueron centrifugadas (Centrifuge Digisystem Laboratory Instrument, Inc; Modelo DSCI58T, Taiwan) a $3.500 \mathrm{G} \times 10 \mathrm{~min}$, obtenido el suero y fraccionándolo en alícuotas de $1 \mathrm{~mL}$ y éstos fueron conservados a $-20^{\circ} \mathrm{C}$ (Thermo Scientific ${ }^{\mathrm{TM}}$, GP Series; USA) hasta su procesamiento.

\section{Población y muestra bovina}

En todo el estado Bolívar, para el momento del estudio, se sacrificaban aproximadamente de 9.000 a 9.100 cabezas de ganado bovino en un mes, de los cuales 3.000 se benefician en el matadero de Soledad, municipio Independencia, que suplía las funciones del matadero del municipio Angostura del Orinoco; 3.500, en el matadero Maloca C.A. de San Félix; 850 en el Matadero Municipal de Upata; 300 en la Sala de Matanza Municipal de El Callao; 580 en la Sala de Matanza Municipal de Guasipati; 450 en la Sala de Matanza Municipal de Tumeremo y 300 en la Sala de Matanza Municipal de El Palmar. 
De un total de 303 bovinos seleccionados en un día (d) de matanza (100\%), se estudiaron 115 bovinos (37,9\%) en el matadero Maloca C.A. de San Félix; 97 (32,0 \%) en el Matadero Municipal de Soledad, municipio Independencia del Edo. Anzoátegui; 30 (9,9\%) en el Matadero Municipal de Upata; 19 (6,3\%) en la Sala de Matanza Municipal de Guasipati; 17 (5,6 \%) en la Sala de Matanza Municipal de El Palmar; 15 (5,0 \%) en la Sala de Matanza Municipal de Tumeremo y 10 (3,3\%) en la Sala de Matanza Municipal de El Callao.

En cada uno de los mataderos se tomó una muestra de sangre venosa yugular (8 - $10 \mathrm{~mL}$ ) en tubos sin anticoagulante (Vacutainer $^{\circledR}$ ), de la totalidad de los bovinos que fueron llevados para sacrificio al matadero, en un d de matanza escogido al azar, sin historia clínica confirmada de brucelosis. Se separó el suero y se congeló a $-40^{\circ} \mathrm{C}$ (Thermo Scientific ${ }^{\top M}$, TSX, USA) hasta el momento de la realización de las diferentes pruebas. Todas las muestras fueron conservadas hasta su procesamiento en el Departamento de Parasitología y Microbiología de la Universidad de Oriente, Núcleo Bolívar.

La recolección de las muestras, en los bovinos, de los diferentes mataderos se realizó en el período comprendido desde enero a septiembre del año 2006.

\section{Pruebas serológicas}

Se empleó la prueba inmunoenzimática indirecta para la detección de anticuerpos IgM frente a Brucella spp. en suero humano, DRG ${ }^{\circledR}$ Brucella IgM ELISA (EIA-3456), DRG International, Inc USA [11]. La detección de anticuerpos contra Brucella spp. en los bovinos se realizó mediante la prueba de ELISA competitiva, Brucella-Ab C-ELISA de SVANOVIR ${ }^{\circledR}$, ésta se utiliza para la detección de los anticuerpos de Brucella spp. en suero, de manera confiable y rápida, discriminando entre los animales infectados y vacunados, además de ser una prueba multiespecie (sensibilidad del 98,0 \% y especificidad el 99,7\%) [32]. Estas pruebas fueron realizadas e interpretadas siguiendo las recomendaciones del fabricante.

\section{Análisis estadístico}

Se realizó estadística descriptiva. Las variables cualitativas se expresaron indicando las frecuencias absolutas y la proporción de cada una de las categorías, y las cuantitativas con sus medias y desviaciones estándar. Se empleó la prueba de Ji al cuadrado $\left(\mathrm{Ji}^{2}\right)$ y el Test Exacto de Fisher para comparar las variables cualitativas. El nivel de significación utilizado fue $P \leq 0,05$. Se utilizó el paquete estadístico SPSS versión 21,0 para ordenador IBM.

\section{RESULTADOS Y DISCUSIÓN}

Se procesaron un total de 462 muestras de sueros, de las cuales 159 fueron obtenidas de los trabajadores y 303 de los bovinos. Los trabajadores evaluados tenían una edad media de 36,5 \pm 12,3 años (a), con un rango entre 14 y $71 \mathrm{a}$, siendo predominante el grupo etario entre 31 - 40 a de edad y el género masculino $(n=152 ; 95,6 \%)$.

Los anticuerpos específicos contra Brucella spp. fueron demostrados en 9 trabajadores, lo que representó una prevalencia del 5,6\%. El mayor porcentaje de seropositividad se evidenció en el grupo entre 21 a 30 a de edad ( $n=5 ; 3,1 \%)$, predominando el sexo masculino $(n=8 ; 5,1 \%)(P=0,34)$. Sólo una mujer $(0,6 \%)$ resultó positiva; hay que destacar que ella era veterinaria $\mathrm{e}$ inspectora de salud pública de las salas de matanzas del estado Bolívar $(P>0,05)$.

La mayor prevalencia de anticuerpos contra Brucella spp. se encontró en población joven con edades comprendidas entre 21 a $30 \mathrm{a}$, coincidiendo con algunos estudios realizados en México [22]. A diferencia de otros realizados en Almería, España, donde predomina en el grupo comprendido entre 40 y 49 a [16]; esto evidencia una diferencia en la mayoría de las series y probablemente se deba en gran parte al período de mayor actividad laboral en cada región. La mayoría de los trabajadores eran del sexo masculino, lo que coincide con otros investigadores $[16,22,29]$ y guarda relación con la ocupación que los expone a esta enfermedad.

Este estudio demostró una baja seroprevalencia de infección por Brucella spp. (5,6 \%) en los trabajadores de los mataderos evaluados, coincidiendo con otra investigación realizada en el país [5]. Prevalencias elevadas han sido registradas en otras latitudes como Irán (29,8 \%) [12], Pakistán (21,7\%) [24], México (18,1 \%) [8], India (9,9\%) [2], Kyrgyzstan (8,8 \%) [6] y Malasia (5,4\%) [19]. Cifras inferiores de seroprevalencia en humanos se han descrito en Brasil (0,6 \%) [17] y Bangladesh (4,4 \%) [27].

Hubo predominio de la infección por Brucella spp. en los trabajadores del matadero de San Félix $(n=4 ; 2,5 \%)$ seguido del de Tumeremo $(n=3 ; 1,8 \%)(P>0,05)$, lo que implica que no hay diferencias entre los mataderos, aunque la frecuencia de uno sea mayor que el del otro (TABLA I).

\section{TABLA I}

Anticuerpos específicos contra Brucella spp. en trabajadores de las salas de matanzas según grupo etario, sexo y ubicación de mataderos en el Edo. Bolívar y Soledad municipio Independencia (Edo. Anzoátegui)

\begin{tabular}{ccrr}
\hline & \multicolumn{3}{c}{ Anticuerpos contra Brucella spp. } \\
Variables & Negativo (\%) & Positivo $(\%)$ & Total $(\%)$ \\
\hline EDAD (años)* & & & \\
$10-20$ & $0(0,0)$ & $18(11,3)$ & $18(11,3)$ \\
$21-30$ & $5(3,1)$ & $33(20,8)$ & $38(23,9)$ \\
$31-40$ & $1(0,6)$ & $44(27,7)$ & $45(28,3)$ \\
$41-50$ & $3(1,9)$ & $31(19,5)$ & $34(21,3)$ \\
$51-60$ & $0(0,0)$ & $21(13,2)$ & $21(13,2)$ \\
$>60$ & $0(0,0)$ & $3(1,9)$ & $3(1,9)$ \\
Total & $9(5,6)$ & $150(94,4)$ & $159(100,0)$ \\
\hline SEXO** & & & \\
Masculino & $8(5,1)$ & $144(90,5)$ & $152(95,6)$ \\
Femenino & $1(0,6)$ & $6(3,8)$ & $7(4,4)$ \\
\hline MATADEROS & & & \\
San Félix & $4(2,5)$ & $32(20,1)$ & $36(22,6)$ \\
Tumeremo & $3(1,8)$ & $9(5,6)$ & $12(7,5)$ \\
Upata & $2(1,3)$ & $26(16,3)$ & $28(17,6)$ \\
Soledad & $0(0,0)$ & $28(17,6)$ & $28(17,6)$ \\
Guasipati & $0(0,0)$ & $20(12,6)$ & $20(12,6)$ \\
El Callao & $0(0,0)$ & $18(11,3)$ & $18(11,3)$ \\
El Palmar & $0(0,0)$ & $17(10,7)$ & $17(10,7)$ \\
\hline
\end{tabular}

${ }^{*} \mathrm{j}^{2}=8,021: 5^{\circ} \mathrm{L} ; \mathrm{P}=0,155 ; * \star \mathrm{j}^{2}=1,020: 1^{\circ} \mathrm{L} ; \mathrm{P}=0,340$ 
Se registró mayor frecuencia de infección por Brucella spp. en el personal que tenía menos de 10 a con riesgo ocupacional $(n=6$; $3,8 \%$ ). El cargo de matarife mostró el mayor número de casos seropositivos $(n=5 ; 3,1 \%)$, seguido del de despostador $(n=2$; $1,2 \%)$ (TABLA II).

La frecuencia de seropositividad a Brucella spp. depende en gran medida del tiempo de exposición al riesgo y del contacto directo con los animales o sus derivados [16, 27], así como fue demostrado en el presente estudio con la ocupación de matarife y despostador. Lo anterior, también es válido con la ocupación previa, y se demuestra porque la mayoría de los casos seropositivos fueron aquellos trabajadores que tenían el

Tabla II

Prevalencia de anticuerpos específicos contra Brucella spp. según años de trabajo, ocupación actual y previa en el Edo. Bolívar y Soledad municipio Independencia (Edo. Anzoátegui)

\section{Anticuerpos contra Brucella spp.}

Variables

Positivos Negativos

Total

(\%)

(\%)

(\%)

Tiempo (años) *

\begin{tabular}{cccc}
$\leq 10$ & $6(3,8)$ & $96(60,4)$ & $102(64,2)$ \\
$>10$ & $3(1,8)$ & $54(33,9)$ & $57(35,8)$ \\
Total & $9(5,6)$ & $150(94,4)$ & $159(100,0)$ \\
\hline
\end{tabular}

Ocupación actual

$\begin{array}{lrrr}\text { Matarife } & 5(3,1) & 68(42,8) & 73(45,9) \\ \begin{array}{l}\text { Despostador } \\ \text { Inspector de } \\ \text { salud pública }\end{array} & 2(1,2) & 8(5,0) & 10(6,2) \\ \quad 1(0,6) & 6(3,8) & 7(4,4) \\ \quad \text { Cavero } & 1(0,6) & 9(5,6) & 10(6,2) \\ \begin{array}{l}\text { Ayudante de } \\ \text { Matarife }\end{array} & 0(0,0) & 17(10,7) & 17(10,7) \\ \text { Mondonguero } & 0(0,0) & 13(8,2) & 13(8,2) \\ \text { Carnicero } & 0(0,0) & 8(5,0) & 8(5,0) \\ \text { Otros** } & 0(0,0) & 21(13,2) & 21(13,2)\end{array}$

\section{Ocupación previa***}

\begin{tabular}{crrr} 
Matarife & $4(2,5)$ & $30(18,8)$ & $34(21,4)$ \\
No refiere & $2(1,2)$ & $45(28,3)$ & $47(29,6)$ \\
Carnicero & $1(0,6)$ & $7(4,4)$ & $8(5,0)$ \\
Veterinario & $1(0,6)$ & $6(3,7)$ & $7(4,3)$ \\
Otros (mecánico) & $1(0,6)$ & $55(34,5)$ & $56(35,1)$ \\
Ordeñador & $0(0,0)$ & $7(4,4)$ & $7(4,4)$ \\
Total & $9(5,6)$ & $150(94,4)$ & $159(100,0)$ \\
\hline
\end{tabular}

${ }^{*} \mathrm{j}^{2}=0,026: 1^{\circ} \mathrm{L} ; \mathrm{P}=0,589 ;$ **Otros: caporal, ordeñador, becerrero, sabanero; $* * \star \mathrm{j}^{2}=6,281: 1^{\circ} \mathrm{L} ; \mathrm{P}=0,616$

antecedente de haber trabajado como matarifes y de manipular placentas, que es uno de los tejidos por los que estas bacterias tienen mayor afinidad $[12,27]$.

En la TABLA III se muestran otros factores de riesgo de los trabajadores, siendo frecuente el consumo de derivados lácteos sin pasteurizar $(95,6 \%)$, la manipulación de placenta $(45,3 \%)$ y el desconocimiento de los riesgos de su ocupación (35,8 \%). Además, el 95,6 \% de los trabajadores consumían derivados lácteos sin pasteurizar, y se ha descrito que éste es otro factor de riesgo para adquirir la infección por Brucella spp. [27, 30]. Otro factor de riesgo importante fue, que los trabajadores no utilizaban las medidas de protección (ni guantes, ni protectores nasales). La forma de transmisión aérea de la brucelosis es importante [15, $24,25,27] \mathrm{y}$, el riesgo de laceraciones representa una puerta de entrada para las bacterias [15, 16, 24].

Posiblemente, este comportamiento se debe al desconocimiento de los trabajadores sobre los diferentes mecanismos de trasmisión de la brucelosis. A pesar de que la mayoría de los trabajadores estaban expuestos a múltiples factores de riesgo para contraer

Tabla III

Factores de riesgo ocupacionales y manifestaciones clínicas en trabajadores de los mataderos del Edo. Bolívar y Soledad municipio Independencia (Edo. Anzoátegui)

\begin{tabular}{ccc}
\hline & $\begin{array}{c}\text { Presencia de } \\
\text { anticuerpos } \\
\text { contra }\end{array}$ & $\begin{array}{c}\text { Ausencia de } \\
\text { anticuerpos } \\
\text { contes }\end{array}$ \\
& Brucella spp. (\%) & Brucella spp. (\%) \\
\hline
\end{tabular}

\section{Factores de riesgos*}

Consumo de derivados

lácteos sin pasteurizar

$152(95,6)$

$7(4,4)$

Manipulación

de placenta

Conocimientos sobre

riesgos del trabajo

Conocimiento

sobre brucelosis

Uso de guantes y

protectores de nariz

Manifestaciones

clínicas**

Artralgia

$72(45,3)$

$87(54,7)$

$57(35,8)$

$102(64,2)$

$43(27,0)$

$116(73,0)$

$7(4,4)$

$152(95,6)$

Asintomáticos

$5(3,1)$

$59(37,1)$

$3(1,8)$

$60(37,7)$

Cefalea

$3(1,8)$

$41(25,7)$

Fiebre

$2(1,2)$

$27(16,9)$

Sudoración nocturna $\quad 2(1,2)$

$33(20,8)$

Pérdida de apetito (anorexia)

* $\mathrm{j}^{2}=9,481: 1^{\circ} \mathrm{L} ; \mathrm{P}=0,512 ; * \star \mathrm{j}^{2}=5,154: 1^{\circ} \mathrm{L} ; \mathrm{P}=0,382$ 
brucelosis, esta seroprevalencia no deja de ser importante ya que se trata de una enfermedad con implicaciones en la salud humana y en la economía del país.

Las manifestaciones clínicas referidas por los trabajadores fueron: artralgias $(n=64 ; 40,3 \%)$, cefalea $(n=44 ; 27,7 \%)$ y sudoración nocturna $(n=35 ; 22,0 \%)$. Las artralgias predominaron en los pacientes seropositivos a Brucella spp. $(n=5 ; 3,1 \%)$. No se demostró asociación estadísticamente significativa entre las manifestaciones clínicas encontradas y la seropositividad a Brucella spp. $(P>0,05)$.

Los principales signos y síntomas que manifestaron los trabajadores eran inespecíficos, resultados similares ha sido evidenciados por otros autores [2, 6, 8].

De las 303 muestras de sueros obtenidas de los bovinos, se obtuvo una prevalencia de infección IgM por Brucella spp. del $11,2 \%(n=34)$. La mayor seropositividad se obtuvo en los mataderos ubicados en El Palmar, Upata y Soledad $(n=9 ; 2,9 \%$ en cada uno), seguido de San Félix y Guasipati ( $n=3 ; 0,9 \%$, respectivamente) y Tumeremo $(n=1 ; 0,3 \%)$. En el matadero ubicado en El Callao no se detectaron anticuerpos en los bovinos.

En el caso de los bovinos, la seroprevalencia de infección por Brucella spp. fue elevada (11,2\%); similar a la descrita en caprinos en el país [9, 20]. En otras regiones de Venezuela se han señalado cifras elevadas de prevalencia de infección por Brucella spp., en Lara (13,1 \%) [23] y en el estado Zulia (20,3 \%) [10]; así como también valores inferiores a la señalada en este estudio: $9 \%$ en Barinas y 2,9 \% en Guárico [31, 33].

En otras regiones de Latinoamérica se han señalado prevalencias superiores de brucelosis bovina, por ejemplo, en Colombia entre 1,7 a 32,2 \% [1], $0 \%$ en México [4], en la provincia de Parinacochas, Ayacucho, Perú, está ausente y en el caso de existir tendría una prevalencia inferior a 4,7\% [34] y en Chile un $5 \%$ [13].

En otras latitudes se registran seroprevalencias de brucelosis inferiores a la demostrada en esta investigación, como por ejemplo en Egipto $(0,79 \%)$ [18]. En el sur de África, la prevalencia fue 11,0 \% (22 de 200), similar a la demostrada en este estudio, empleando otra técnica diagnóstica; aunque cuando se utilizó la prueba de ELISA en la misma población de bovinos, la prevalencia fue mucho menor 5,5\% (11 de 200) [21].

La seroprevalencia demostrada en bovinos, tiene especial importancia ya que representa un riesgo ocupacional, donde están expuestos, tanto el personal que labora en los mataderos como la población en general.

La seroprevalencia de brucelosis se corrobora con los informes que muestran una tasa media positiva del 10,5 \% y valores aún más altos en algunas zonas del país [9, 10, 14].

Se recomienda realizar pruebas de serologías frecuentes, vigilancia continua, la implementación de medidas preventivas que eviten la entrada del patógeno al rebaño, así como aplicación de vacunas, las cuales podrían ser efectivas en el control de la incidencia de la infección por Brucella spp.

Las autoridades de salud pública deben educar a los agricultores, ganaderos y al público en general con respecto a la prevención de la enfermedad, con especial hincapié a las personas con riesgo ocupacional y en especial aquellas que trabajan en los mataderos. Como la brucelosis es clínicamente inespecífica, debería incluirse sistemáticamente en el diagnóstico etiológico de las enfermedades infecciosas en estas poblaciones en riesgo.

\section{CONCLUSIONES}

La mayoría de los trabajadores de los mataderos evaluados del estado Bolívar y de Soledad, municipio Independencia, estado Anzoátegui, están expuestos a múltiples factores de riesgo para contraer brucelosis; sin embargo, la seroprevalencia de brucelosis en ellos fue baja (5,6 \%), aunque elevada entre los bovinos (11,2\%). Estos hallazgos confirman que la infección por Brucella spp., circula entre el ganado vacuno que se consume y demuestra un riesgo para los trabajadores en los mataderos seleccionados y para los consumidores de carne de res o lácteos, cocidos de manera inadecuada o no pasteurizados, siendo necesarios programas de control.

\section{REFERENCIAS BIBLIOGRÁFICAS}

[1] ANDRADE-BECERRA, R.J.; VARGAS, J.C. Seroprevalencia de Brucelosis bovina en el Altiplano Boyacense, ColombiaSuramérica. Rev. Científ. FCV-LUZ. XXIX (3): 192-197. 2019.

[2] APPANNANAVAR, S.B.; SHARMA, K.; VERMA, S.; SHARMA, $M$. Seroprevalence of Brucellosis: a 10-year experience at a tertiary care center in north India. Indian J. Pathol. Microbiol. 55:271-272. 2012.

[3] ASAMBLEA GENERAL UNESCO 59 ${ }^{\mathrm{TH}}$., SEUL, COREA. Declaración de Helsinki de laAsociación Médica Mundial. Principios éticos para las investigaciones médicas en seres humanos, octubre 2008. En línea: https://bit.ly/3gp4nmQ. 01.12.2015.

[4] BARAJAS, J. Aplicación de la técnica inmunoenzimática de Elisa para estudios epidemiológicos de enfermedades de ganado bovino en el trópico de México. Rev. Cien. Vet. 8: 85-151. 1998.

[5] Bello, A.; MARÍN, C.; MOGOLLÓN, P.; HERRERA, M.; PACHECHO, S.; RODRÍGUEZ, M.; GIL, R.; DE LASERNA, R.; DE SALMERON, C. Estudios epidemiológicos sobre brucelosis humana suina, canina y humana en establecimientos agrícolas de Punta Palmita (Venezuela) 1975. Vet. Trop. 3:3 - 14. 1978.

[6] BONFOH, B.; KASYMBEKOV, J.; DÜRR, S.; TOKTOBAEV, N.; DOHERR, M.G.; SCHUETH, T.; ZINSSTAG, J.; SCHELLING, E. Representative seroprevalences of brucellosis in humans and livestock in Kyrgyzstan. EcoHealth. 9:132-138. 2012.

[7] CAMPOS, V.M.; PÉREZ, M.; CÓRDOVA, A. Evaluation of the Economic Losses of Events Associated With Reproductive Failure in Female Bovine Brucellosis and Dairy Farms of the Basin of Tizayuca, Hidalgo, Mexico. Rev. Científ. FCV-LUZ. XX (2): 190-195. 2010.

[8] CERVERA-HERNÁNDEZ, M.E.; ORDAZ-VÁZQUEZ, A.; TORRES-GONZÁLEZ, P.; CHÁVEZ-MAZARI, B.; SOBERANISRAMOS, O.; SIFUENTES-OSORNIO, J.; PONCE DE LEÓN, A.; BOBADILLA DEL V., M. Seroprevalence of brucellosis among dairy farm workers in Mexico. Sal. Pub. Mex. 58:36670. 2016.

[9] DE LORD, V.; NIETO, S.; SANDOVAL, E.; MELÉNDEZ, G.; RUIZ, R. Brucelosis en caprinos: Estudios serológicos y bacteriológicos en Venezuela. Vet. Trop. 12: 27-37. 1987. 
[10] D`POOL, G.; RIVERA, S.; TORRES, T.; PÉREZ, M.; GARCÍA, A.; CASTEJÓN, O.; ROJAS, N. Prevalencia de brucelosis bovina mediante ELISA competitivo en el Municipio de Cañada de Urdaneta, estado Zulia, Venezuela. Rev. Científ. FCV-LUZ. XIV (2): 168-176. 2004.

[11] DRG INTERNATIONAL, INC. USA. DRG® Brucella IgM ELISA (EIA-3456). 2011. En línea: https://bit.ly/3wBtTKY. 15.10.2006

[12] ESMAEILI, S.; BAGHERI-AMIRI, F.; MOKHAYERI, H.; KAYEDI, M.H.; MAURIN, M.; ROHANI, M.; MOSTAFAVI, E. Seroepidemiological study of $\mathrm{Q}$ fever, brucellosis and tularemia in butchers and slaughterhouses workers in Lorestan, western of Iran. Comp. Immunol. Microbiol. Infect. Dis. 66:101-322. 2019.

[13] FELMER, R.; ZUÑIGA, J.; LÓPEZ, A.; MIRANDA, H. Prevalencia y distribución espacial de brucelosis, leucosis bovina, diarrea viral bovina y rinotraqueitis infecciosa bovina a partir del análisis ELISA de estanques prediales en lecherías de la IX Región, Chile. Arch. Med. Vet. 41:17-26. 2009.

[14] FRANCISCO, J.; VARGAS, O. Brucellosis in Venezuela. Vet. Microbiol. 90: 39-44. 2002.

[15] FRANC, K.A.; KRECEK, R.C.; HÄSLER, B.N.; ARENASGAMBO, A. Brucellosis remains a neglected disease in the developing world: a call for interdisciplinary action. BMC Public Health. 18:1-9. 2018.

[16] GARCíA, P.; CARREÑO, T.; ROdRíGuEZ, R. Estudio descriptivo de la brucelosis en la provincia de Almería. Evolución de los mecanismos de transmisión. Med. Famil. 2: 46-52. 2001.

[17] GONÇALVES, D.D.; TELES, P.S.; DOS REIS, C.R.; LOPES, F.M.; FREIRE, R.L.; NAVARRO, I.T.; ALVES, L.A.; MULLER, E.E.; DE FREITAS, J.C. Seroepidemiology and occupational and environmental variables for leptospirosis, brucellosis and toxoplasmosis in slaughterhouse workers in the Paraná State, Brazil. Rev. Inst. Med. Trop. Sao Paulo. 48:135-140. 2006.

[18] HEGAZY, Y.M.; MOLINA-FLORES, B.; SHAFIK, H.; RIDLER, A.L.; GUITIAN, F.J. Ruminant brucellosis in Upper Egypt (2005-2008). Prev. Vet. Med. 101:173-181. 2011.

[19] JAMA'AYAH, M.Z.; HEU, J.Y.; NORAZAH, A. Seroprevalance of brucellosis among suspected cases in Malaysia. Malays. J. Pathol. 33: 31-34. 2011.

[20] JAVITT-JIMENEZ, M.J.; PÁEZ, Z.; DURAN, J.; MELÉNDEZ, I. Seroprevalencia de la brucelosis en pequeños rumiantes. Municipio Torres. Año 2008. REDVET. 2009. 10(8). En línea: https://bit.ly/3pRsVI9. 27.02.2019.

[21] KOLO, F.B.; ADESIYUN, A.A.; FASINA, F.O.; KATSANDE, C.T.; DOGONYARO, B.B.; POTTS, A.; MATLE, I.; GELAW, A.K.; VAN HEERDEN, $\mathrm{H}$. Seroprevalence and characterization of Brucella species in cattle slaughtered at Gauteng abattoirs, South Africa. Vet. Med. Sci. 5(4):545-555. 2019.

[22] LOPES, E.; MIGRANAS, R.; PÉREZ, A.; MAGOS, C.; SALVATIERRA, B.; TAPIA-CONVER, R.; VALDESPINO, J.L.; SEPÚLVEDA, J. Seroepidemiología de la brucelosis en México. Sal. Publ. Mex. 34: 230-240. 1992.

[23] MALDONADO, J.; KOWALSKI, A. MILLA, M.; RODRÍGUEZ, M.; VILLASMIL, C. Implementación de la prueba del anillo en leche y ELISA indirecto para el diagnóstico de Brucelosis en rebaños de doble propósito en el estado Lara, Venezuela. Rev. Científ. FCV-LUZ. XX (3):240-244. 2010.

[24] MUKHTAR, F. Brucellosis in a high risk occupational group: seroprevalence and analysis of risk factors. J. Pak. Med. Assoc. 60:1031-1034. 2010.

[25] NJERU, J.; WARETH, G.; MELZER, F.; HENNING, K.; PLETZ, M.W.; HELLER, R.; NEUBAUER, H. Systematic review of brucellosis in Kenya: disease frequency in humans and animals and risk factors for human infection. BMC Public Health. 16(1):1-15. 2016.

[26] PAPPAS, G.; PAPADIMITRIOU, P.; AKRITIDIS, N.; CHRISTOU, L.; TSIANOS, E.V. The new global map of human brucellosis. Lancet Infect. Dis. 6: 91-99. 2006.

[27] RAHMAN, A.K.; DIRK, B.; FRETIN, D.; SAEGERMAN, C.; AHMED, M.U.; MUHAMMAD, N.; HOSSAIN, A.; ABATIH, E. Seroprevalence and risk factors for brucellosis in a high-risk group of individuals in Bangladesh. Foodborne Pathog. Dis. 9:190-197. 2012.

[28] RIVERA, S.; CURIEL, J.; ROJAS, N.; SANGRONI, I.; URDANETA, N. Epidemiología serológica de la Brucelosis Bovina en el Municipio Rosario de Perijá (Zulia. Venezuela). Rev. Científ. FCV-LUZ. V (2): 117-124. 1995.

[29] SERRA, J.; GODOY, P. Incidencia, etiología y epidemiología de la brucelosis en un área rural de la provincia de Lleida. Rev. Esp. Sal. Publ. 74: 45-53. 2000.

[30] SHIMOL, S.B.; DUKHAN, L.; BELMAKER, I.; BARDENSTEIN, S.; SIBIRSKY, D.; BARRETT, C.; GREENBERG, D. Human brucellosis outbreak acquired through camel milk ingestion in southern Israel. Isr. Med. Assoc. J. 14: 475-478. 2012.

[31] SOTO-REVEROL, N. Seroprevalencia de la Brucelosis y su impacto reproductivo en un Rebaño Brahman. 2013. Rev. Col. Med. Vet. Edo. Lara. 3:5(1). En Línea: https://bit. ly/3wqSwdx.1.04.2020

[32] SVANOVA BIOTECH, AB. Brucella - Ab competitive C-ELISA. SVANOVIR ${ }^{\circledR}$. ELISA test for the detection of Brucella antibodies in serum. 2006. Discriminating between infected and vaccinated animals. En Línea: https://bit.ly/3iGxkvZ. 1.07.2015

[33] TAMASAUKAS, R.; PURROY, R.; RODRÍGUEZ, H.; RUIZ, I.; ROA, N.; LABRADOR, C. Seroprevalencia de tripanosomiasis y brucelosis bovina en fincas integradas a la producción de maíz, de la zona alta de los Municipios Roscio y Ortiz, Edo. Guárico, Venezuela. Rev. Científ. FCV-LUZ. XII (Supl 2): 630-634. 2002.

[34] VALDIVIA, L.; RIVERA, H. Seroprevalencia de Brucella spp. en bovinos criollos de crianza extensiva de la provincia de Parinacochas, Ayacucho. Rev. Inv. Perú. 14: 174-177. 2003.

[35] VARGAS, F. Situación epidemiológica de la brucelosis en Venezuela. Gac. Cien. Vet. 8: 1-15. 2003.

[36] WHATMORE, A.M.; KOYLASS, M.S.; MUCHOWSKI, J.; EDWARDS-SMALLBONE, J.; GOPAUL, K.K.; PERRETT, L.L. Extended multilocus sequence analysis to describe the global population structure of the genus Brucella: phylogeography and relationship to biovars. Front. Microbiol. 7:2049. 2016. 


\title{
Fattening performance and carcass traits of implanted and supplemented grassfed bulls
}

\author{
Desempeño en la ceba a pastoreo y rasgos de la canal de toros implantados y \\ suplementados
}

\begin{abstract}
Nelson Huerta-Leidenz' ${ }^{1,2 *}$ (D), Nancy Jerez-Timaure ${ }^{1,3}$ iD, Susmira Godoy ${ }^{4}$ iD, Carlos Rodríguez-Matos ${ }^{5}$ y Omar Araujo-Febres $^{1}$ iD
${ }^{1}$ Facultad de Agronomía, Departamento de Zootecnia, Universidad del Zulia. Maracaibo, Venezuela. ${ }^{2}$ Department of Animal and Food Sciences, Texas Tech University. Texas, USA. ${ }^{3}$ Instituto de Ciencia Animal, Facultad de Ciencias Veterinarias, Universidad Austral de Chile. Valdivia, Chile. ${ }^{4}$ Instituto Nacional de Investigaciones Agrícolas. Centro Nacional de Investigaciones Agropecuarias. Maracay, Aragua, Venezuela. ${ }^{5}$ Hato Santa Luisa C. A. Caracas, Venezuela. *Email: nelson.huerta@ttu.edu
\end{abstract}

\begin{abstract}
Ninety-nine uncastrated males were randomly distributed into four grazing groups to examine variation in growth and carcass traits, due to the implant regime [Implantation of 72 miligrams $(\mathrm{mg})$ of Ralgro $\AA$ at day (d) 0 followed by its reimplantation at $d 90$ versus implantation of Revalor $\AA$ at d 0 followed by $72 \mathrm{mg}$ of Ralgro® at d 90)], and suplementation type [mineral supplementation (MS) versus strategic supplementation (SS)]. With a $2 \times 2$ factorial arrangement, the analysis of variance included the treatments and their interaction (implant regimen $\mathrm{x}$ supplementation) as fixed effects, and the breed type as a random effect. The interaction was not significant; neither did the implant regimen on any growth trait $(P>0.05)$. Compared to $M S$, the SS group had a greater daily weight gain (779 vs. 541 grams; $P<0.001$ ), required a shorter (38.3 d lesser) time of fattening to reach the end point (198.3 versus $236.6 \mathrm{~d} ; \mathrm{P}<0.001$ ) with a heavier liveweight (498. 2 vs. 474.4 kilograms; $P=0.02)$ at an earlier age (29.4 vs. 30.8 months; $\mathrm{P}<0.001)$, with a higher carcass dressing percentage (59.13 vs $57.62 \% ; P=0.03$ ) and younger carcass bone maturity $(P<0.001)$. With the exception of thoracic depth, carcass traits did not vary with the implant regimen $(P>0.05)$. The use of aggressive implant regimens to improve growth or carcass characteristics of grazing bulls is not justified. SS is a feasible practice to improve fattening performance of grazing bulls but no beneficial impact on their carcass quality was expected.
\end{abstract}

Key words: Strategic supplementation; implants; bull; beef carcass; Brahman

\section{RESUMEN}

Noventa y nueve machos sin castrar se distribuyeron al azar en cuatro grupos a pastoreo para examinar la variación en rasgos de crecimiento y en canal, debida a régimen de implantes [72 miligramos (mg) de Ralgro® el día (d) 0 seguido de su reimplante el d 90 versus implantación de Revalor ${ }^{\circledR}$ el d 0 seguido de $72 \mathrm{mg}$ de Ralgro® el d 90] y suplementación [mezcla mineral (SM) versus suplemento estratégico (SE)]. El análisis de varianza con arreglo factorial $2 \times 2$ incluyó, como efectos fijos, los tratamientos y su interaccion (régimen de implantes $x$ suplementación) y tipo racial como efecto aleatorio. En rasgos de crecimiento, la interacción no fue significativa $(P>0,05)$; tampoco lo fué el régimen de implante $(P>0,05)$. El grupo con $\mathrm{SE}$, con respecto al que recibió $\mathrm{SM}$, tuvo mayor ganancia diaria de peso (779 vs. 541 gramos; $\mathrm{P}<0,001$ ) requirió 38,3 d menos de ceba [(198,3 versus 236,6 d; $(P<0,001)]$ para alcanzar mayor peso vivo final $(498,2$ versus 474,4 kilogramos; $P=0,02)$ a una edad más temprana $(29,4$ versus 30,8 meses; $P<0,001)$, con mayor rendimiento en canal $(59,13$ versus $57,62 \% ; P=0,03)$ y una menor madurez ósea de la canal $(P<0,001)$. A excepción de la profundidad torácica, los rasgos en canal no variaron con el régimen de implantes $(P>0,05)$. La falta de respuesta en crecimiento o rasgos importantes de la canal a estos regímenes agresivos de implantes, no permite justificar su uso para cebar toros en pastoreo. La SE es una práctica factible para mejorar el desempeño de toros en la ceba a pastoreo, pero no puede esperarse beneficio alguno en la calidad de sus canales.

Palabras clave: Suplementación estratégica; implantes; toros; canales, Brahman 


\section{INTRODUCTION}

With the construction of dikes (modules) to control floods and to have water available during the dry season [32], the native vegetation of the lower plains of Apure State (Venezuela) has been replaced with better forage (e.g., Brachiaria spp.) resources [21]. However, during the seasonal drought, the nutritional quality of cultivated grasses can drop to levels that impair the biological response of genetically improved cattle [27] even with mineral or mineral-protein supplementation [9].

The unsuccessful attempts to improve the response of cattle with greater genetic potential indicate the need for ad hoc application of technological packages; particularly, when the ranchers in the area intend to fatten cattle at the same breeding operation and harvest them in packing houses authorized for carcass classification and grading, hoping for a better return on investment [17, 29, 30]. Synthetic anabolic implants, based on steroidal compounds such as trenbolone acetate $+17 \beta$-estradiol (ATB + E17) and non-steroidal, estrogenic compounds, such as Zeranol (a lactone of resorcylic acid, Ralgroß) constitute technological resources widely used to improve the response in productive performance and the lean: fat ratio in carcasses of castrated males (steers); especially under intensive fattening in North America [1, 3, 33]. On the contrary, few studies have evaluated the response of entire males (bulls or bullocks) to anabolics, yielding null or inconsistent results [12, 23 - 25]. Potent implants (e.g., ATB + E17), as well as more aggressive anabolic combinations or strategies, administered to predominantly Bos taurus steers during intensive fattening, have negatively affected marbling level and the U.S.carcass quality grade [33].

These findings suggest that aggressive implant regimes used to improve fattening performance in grazing bulls with Bos indicus genetics, may have a more detrimental impact on carcass quality. In the low ("modulated') plains of Apure, improvements have been observed in the growth rate of steers and bulls, fattened to grazing with a strategic (catalytic) supplement [6] and in the same ranch an additive supplementation brought about improvements in quality traits of bull carcasses [17]. As the vast majority of cattle in Venezuela are fattened on pasture, there is interest in evaluating the effect of more aggressive implant regimes on the performance of bulls under grazing conditions with a strategic supplementation.

Therefore, the objective of this trial was to examine the responses to aggressive implant regimes and strategic supplementation in growth and carcass traits of bulls, fattened to pastures of cultivated grasses in the lower plains of Apure State.

\section{MATERIALS AND METHODS}

\section{Trial location}

The trial was carried out in a commercial ranch located in the low flood plains of the Apure State (Venezuela). The ecological and soil conditions of the area have been widely described [16, 17, 30, 31, 33]. The ranch has an infrastructure of dikes (modules) for flood control. The grazing module (485 hectares - ha-) consists of 61 paddocks of 7.4 ha each with cultivated pastures and equipped with electric fences (Gallaguer $®$ model- 6 wire electric fences, Australia).

\section{Animal handling}

The animals were grown on the same ranch, so that their management before the grazing trial was very similar. Cattle were dewormed against ecto - and endo-parasites and vaccinated against rabies and foot-and-mouth disease before entering the fattening module on November 14, 1995 when the treatments began. Trained technicians followed the criteria for animal care and welfare described in the Bioethics and Biosafety guide of the Venezuelan Fund for Scientific and Technological Research (FONACIT) [13].

The trial included a total of 99 contemporary intact males (bulls). At the beginning of the trial, the age was $23.0 \pm 0.85$ months (mo.), and the average live weight (LW) was $347.1 \pm 27.9$ kilograms $(\mathrm{kg})$ as determined by a Fairbank-Morse $®$ Livestock, single-animal Scale, LSA series model (USA). According to the feeder cattle grading standards [28] the average frame size was $2.18 \pm 0.6$ (medium) with a muscle thickness of $2.05 \pm 0.6$ (medium). The bulls were randomly assigned to the four treatment groups, optimizing the balance of observations by breed type, initial LW and treatment (TABLE I). To avoid the paddock's effect, the experimental groups were kept under rotational grazing with seven (days) d of occupation and $21 \mathrm{~d}$ rest intervals, in modules of cultivated grasses [Brachiaria arrecta (Tanner grass) and lesser proportion Cynodon nlemfluensis (Star grass), Brachiaria mutica (Pará grass) and Echinochloa polystachya (German grass)].

\section{TABLEI}

Experimental design indicating distribution of observations by breed type, supplementation treatment and implant regime

\begin{tabular}{cccccc}
\hline & \multicolumn{4}{c}{ Treatment $^{1,2}$} & \\
\cline { 2 - 4 } Breed type $^{3}$ & \multicolumn{3}{c}{ Ralgro-Ralgro Revalor-Ralgro } & Total \\
\cline { 2 - 4 } & SS (n) & MS (n) & SS (n) & MS (n) \\
\hline Brahman & 3 & 3 & 3 & 3 & 12 \\
F1-Angus & 3 & 4 & 3 & 6 & 16 \\
F1-Romosinuano & 3 & 5 & 3 & 5 & 16 \\
F1-Senepol & 4 & 5 & 2 & 5 & 16 \\
F1-Simmental & 4 & 5 & 3 & 5 & 17 \\
Brahman cross & 2 & 3 & 4 & 3 & 12 \\
3/4 Bos taurus & 3 & 3 & 2 & 2 & 10 \\
Total & 22 & 28 & 20 & 29 & 99 \\
\hline
\end{tabular}

${ }^{1}$ Implant regime: Ralgro-Ralgro corresponds to double-dosis (72 mg) of Ralgro ${ }^{\circledR}$ at day 0 followed by a second dosis of $72 \mathrm{mg}$ of Ralgro ${ }^{\circledR}$ at day 90; Revalor-Ralgro corresponds to a first dosis of Revalor ${ }^{\circledR}$ at day 0 , followed by a second dosis $(72 \mathrm{mg})$ of Ralgro ${ }^{\circledR}$ at day $90 .{ }^{2}$ Supplementation treatment: mineral supplementation as a positive control (MS) vs. strategic supplementation (SS). ${ }^{3}$ Breed types described as: F1-Angus, F1-Romosinuano, F1-Senepol, and F1-Simmental were obtained by artifical insemination of purebred Brahman cows with semen from bulls of Angus, Romosinuano, Senepol and Simmental breeds, respectively; Brahman cross derived from a herd of Brahman cross cows bred with purebred Brahman bulls; the $3 / 4$ Bos taurus were obtained by natural mating of purebred Romosinuano bulls with F1-Romosinuano x Brahman cows; $\mathrm{n}=$ number of observations. 


\section{Implant regimens}

Two implant regimens were considered: (I) implantation of zeranol (Ralgro $®)$ at double dose [72 miligrams (mg); (2x-Ralgro®)] on d 0 , with reimplantation (2x-Ralgro $($ ) $)$ at $90 \mathrm{~d}$ (Ralgro - Ralgro) and (II) implantation of Revalor $(20 \mathrm{mg}$ of $17 \beta$ - estradiol $+140 \mathrm{mg}$ of Trenbolone acetate) on $\mathrm{d} 0$, with reimplantation of $2 \mathrm{x}$-Ralgro $®$ at $90 \mathrm{~d}$ (Revalor-Ralgro). The implants were subcutaneously placed at the base of the ear of each animal following the manufacturer's instructions. The two implant regimens were randomly assigned to the groups subjected to the supplementation treatments.

\section{Supplementation treatments}

The supplementation effect was measured by comparing the traditional practice of mineral supplementation (MS) against a strategic supplementation (SS). The MS group received the complete mineral mixture at a rate of $80 \mathrm{grams}(\mathrm{g}) \cdot \operatorname{animal}^{-1} \cdot \mathrm{d}^{-1}$, offered continuously, at will. This MS contained $\mathrm{P}$ and $\mathrm{Ca}$, and other macro and micro elements to complement the mineral contribution of the forage (TABLE II). The SS group was manually fed with a supplement $\left(1 \mathrm{~kg} \cdot \mathrm{d}^{-1}\right)$ with a low ruminal load (catalytic) that contained hydrolyzed feather meal, cane molasses, rice polish, a mineral premix with $\mathrm{P}$ and $\mathrm{Ca}$ and an ionophore (Salocin ${ }^{\circledR}$ ) during d 0 -d 60 of the trial (Strategic Supplement-Phase 1; TABLE II). From d 61 to $d$ 182, they received a concentrate (Strategic SupplementPhase 2; TABLE II), which contained the same ingredients of the Strategic Supplement-Phase 1, but in different proportions when adding whole cottonseed, encapsulated bypass fat: ether extract (EE): $22.4 \%$, as an additional source of bypass protein with low ruminal degradability. Protein sources contributed $87.2 \%$ of the total crude protein (CP) of the supplement $(54.7 \%$ cottonseed and $32.5 \%$ feather meal), with a high proportion $(50-70 \%)$ of bypass protein. The supply of the Strategic Supplement-Phase 2 was maintained for ca. $122 \mathrm{~d}$ (until the beginning of August, the rainy season).

\section{Growth performance and endpoint criteria}

The average daily gain (ADG), was determined for the total period of permanence in the module. The average LW at the end of the fattening period was $484.52 \pm 34.70 \mathrm{~kg}$. Bulls were sent to harvest when reaching a satisfactory conformation, as determined by the visual evaluation of three judges, and/or the stability of the daily gain/loss, once a LW of $475 \mathrm{~kg}$ of weight was exceeded. The average shipping LW for transportation to the harvest plant was $509.51 \pm 31.70 \mathrm{~kg}$. The distribution of harvest lots with different fattening $\mathrm{d}$, by treatment, is presented in TABLE III.

\section{Harvest and carcass evaluation}

Dressing procedures and post-mortem inspection in the harvest facility (Matadero Industrial Centro Occidental de Barquisimeto) were carried out in accordance with Venezuelan standards [7]. The hot carcass was weighted and five linear measurements were taken before chilling (width and circumference of the thigh, length of the pelvic limb, carcass length, and thorax depth), according to Huerta-Leidenz et al. [15]. After refrigeration for 48 hours (h) at $4{ }^{\circ} \mathrm{C}$ (using a Vilter ${ }^{\circledR}$ Cooler Ammonia Diffusers, Model UF-42-411/2-RA-HGP, USA), the chilled left sides were quartered between the $12^{\text {th }}$ and $13^{\text {th }}$ rib. Two experienced judges assigned scores for conformation and exterior fat finish, marbling level, physiological
TABLE II

Composition of the forage supplements used in the trial

\begin{tabular}{|c|c|c|c|}
\hline \multirow{2}{*}{$\begin{array}{l}\text { Composition } \\
\text { Ingredient,\% }\end{array}$} & \multicolumn{3}{|c|}{ Supplement ${ }^{1}$} \\
\hline & $\begin{array}{c}\text { Strategic- } \\
\text { Phase } 1\end{array}$ & $\begin{array}{c}\text { Strategic- } \\
\text { Phase } 2\end{array}$ & Mineral \\
\hline Feather meal & 10.0 & 10.0 & - \\
\hline Whole cottonseed & 0.0 & 49.9 & - \\
\hline Rice polish & 77.0 & 27.1 & - \\
\hline Cane molasses & 5.0 & 5.0 & - \\
\hline Mineral premix & 7.0 & 7.0 & - \\
\hline Ionophore $^{2}$ & 1.0 & 1.0 & - \\
\hline \multicolumn{4}{|l|}{ Nutrient } \\
\hline $\mathrm{EME}, \mathrm{kcal} / \mathrm{kg}$ & 2.514 & 2.809 & - \\
\hline $\mathrm{PC}, \%$ & 17.78 & 25.82 & - \\
\hline $\mathrm{P}, \%$ & 1.07 & 0.79 & 12.0 \\
\hline $\mathrm{Ca}, \%$ & 0.12 & 0.17 & 24.0 \\
\hline $\mathrm{Mg}, \%$ & - & - & 1.5 \\
\hline $\mathrm{S}, \%$ & - & - & 1.0 \\
\hline $\mathrm{Mn}, \%$ & - & - & 0.50 \\
\hline $\mathrm{Zn}, \%$ & - & - & 0.75 \\
\hline $\mathrm{Fe}, \%$ & - & - & 0.50 \\
\hline $\mathrm{Cu}, \%$ & - & - & 0.20 \\
\hline $\mathrm{Co}, \%$ & - & - & 0.004 \\
\hline $\mathrm{I}, \%$ & - & - & 0.02 \\
\hline $\mathrm{Se}, \%$ & - & - & 0.004 \\
\hline
\end{tabular}

${ }^{1}$ Strategic supplement-Phase 1 was supplied in the first 60 days of the trial; Strategic supplement-Phase 2 was administered manually from day 60 to day 182 (122 days in total) at a rate of $1 \mathrm{~kg} \cdot$ animal $^{-1} \cdot$ day $^{-1}$. The mineral supplement was offered to the control (MS) group throughout the test with free access $\left(80 \mathrm{~g} \cdot\right.$ animal $\left.^{-1} \cdot \mathrm{day}^{-1}\right) .{ }^{2}$ Salocin $®$ was used as the ionophore.

bone and lean maturities, rib eye area (REA), and back fat thickness over the REA (adjusted with the exterior fat finish) following the stipulated procedures [28, 35]. The adipose maturity was evaluated by the fat color, according to Decree 1896 [28]. The Venezuelan category and the U.S. quality grade were respectively estimated for each carcass [28, 35]. As the kidney, pelvic and peri-cardiac fat depots $(\mathrm{KPH})$ had been removed prior to carcass chilling, its weight, or proportion of the carcass weight could not be assessed. The US yield grade [35] of each bull carcass was estimated assuming a constant KPH percentage value of $1.88 \%$ according to previous data $[6,17]$. 
TABLE III.

Frequency distribution of harvest cattle lots by days of fattening required to reach end point by type of supplementation and implant regimen

\begin{tabular}{cccccc}
\hline \multirow{2}{*}{$\begin{array}{c}\text { Fattening } \\
\text { days }\end{array}$} & \multicolumn{3}{c}{ Type of Supplementation } & \multirow{2}{c}{ MS } & $\mathbf{n}$ \\
\cline { 2 - 4 } & \multicolumn{3}{c}{ SS } & \multicolumn{3}{c}{ MS } & \\
\cline { 2 - 4 } 181 & 5 & 7 & 0 & 1 & 13 \\
195 & 7 & 6 & 0 & 0 & 13 \\
209 & 7 & 5 & 3 & 2 & 17 \\
223 & 3 & 2 & 4 & 9 & 18 \\
237 & 0 & 0 & 12 & 9 & 21 \\
258 & 0 & 0 & 9 & 8 & 17 \\
$\mathrm{n}$ & 22 & 20 & 28 & 19 & 99 \\
\hline
\end{tabular}

${ }^{1}$ Supplementation treaments: whole mineral supplementation (MS); Experimental strategic supplementation (SS). ${ }^{2}$ Implant regimens: RAL-RAL corresponds to double-dosis implant $(72 \mathrm{mg})$ of Ralgro ${ }^{\circledR}$ at day 0 followed by a second dosis of $72 \mathrm{mg}$ of Ralgro ${ }^{\circledR}$ at day 90 ; REV-RAL corresponds to a first dosis of Revalor ${ }^{\circledR}$ at day 0 , followed by a second dosis (72 mg) of Ralgro ${ }^{\circledR}$ at day 90

\section{Statistical analyses}

The R software [11] was used for statistical analyses. Once the fulfillment of the assumptions of normality, independence and sphericity of the variables was verified, the analysis of variance (ANOVA) was performed with a mixed linear model, following a completely randomized design with a $2 \times 2$ factorial arrangement that included, as fixed effects, type of supplementation, implant regimen and their interaction. The breed type was included in the model as a random effect. The multiple comparison of means was made with the Tukey test $(\alpha=0.05)$. The type of supplementation $\mathrm{x}$ implant regimen interaction was not significant; neither was the effect of implant regime on growth traits $(P>0.05)$.

\section{RESULTS AND DISCUSSION}

\section{Pasture nutrient content}

The nutritional contribution of the pasture during the entire trial, with respect to its dry matter (DM) was estimated, on average: total digestible nutrients (TDN), $63 \%$; CP, $6 \%$; nitrogen free extract (NFE), $47 \%$; EE, $1 \%$; crude fiber (CF), $34 \%$; ashes; $11 \%$; calcium (Ca), $1.1 \%$; phosphorus (P), $0.32 \%$. In general, the average chemical composition of the pastures during the dry season, coincides with that reported by Tejos et al. [34] for the same paddocks, indicating a medium - to low-quality cultivated grasses [Tanner (Brachiaria arrecta), Star (Cynodon nlemfuensis), Pará (Brachiaria mutica) and German (Echinochloa polystachya)].

The content (\% DM) of average crude protein (CP) according to Tejos et al. [34] was one percentage point lower (ca. $5.0 \%$ ) than the value of this work's estimates. Assuming the bromatological values reported by Tejos et al. [34], the CP content of the pasture during the dry season could be lower than the cattle requirement (CP: $7 \%$ ) [26], while the content of macro - and micro-elements would present adequate values, with the only exception of copper, slightly lower than the required content $(\mathrm{Cu}$ : 10 parts per million (ppm) [26].

\section{Effects of supplementation on fattening performance}

The mean values and standard error for growth traits and other performance indicators, according to the type of supplementation are given in TABLE IV. The SS group, outperformed the MS counterpart in ADG with an advantage of $227.7 \mathrm{~g}(P<0.001)$. With this faster growth rate, the SS group reached the end point more rapidly (a $38.3 \mathrm{~d}$ shorter fattening period; $\mathrm{P}<0.001$ ), $1.44 \mathrm{mo}$ younger $(P<0.001)$ and $23.81 \mathrm{~kg}$ heavier in final LW $(P=0.02)$.

ADG mean values in three consecutive, annual trials in the same ranch [34] were 587, 532 and $531 \mathrm{~g}$; all lower than the value found herein for the SS group (ca. $769 \mathrm{~g}$ ). A preliminary report from the present trial [5] indicated that the SS group had a faster growth rate during the first supplementation phase $(0-60 \mathrm{~d})$, and this increase in ADG was maintained for $150 \mathrm{~d}$; thereafter, the response was attenuated in relation to the MS group [5]. Also, Byers et al. [5] reported the total consumption of DM by the MS group vs. SS was 15.3 vs. $17.2 \mathrm{~kg} \cdot$ head $^{-1}$ or $84 \mathrm{vs.} 945 \mathrm{~g} \cdot \mathrm{d}^{-1}$ until d 182 [5]. The accelerated growth rate allowed SS cattle to be finished before the start of the rainy season and its commercialization had a price advantage, producing a $2: 1$ return on the SS investment [5].

The mean value for the SS final LW exceeds between 17 to $27 \mathrm{~kg}$ to those reported for bulls of similar age (29 to $30 \mathrm{mo}$ in the same ranch [34] with final LW of $471 \mathrm{~kg}$ (born in 2000), $481 \mathrm{~kg}$ (born in 2001) and $477 \mathrm{~kg}$ (born in 2002). The final LW of SS bulls also tends to be higher than those reported by Plasse et al. [27] for Brahman bulls and four groups of crosses 1/4 Bos taurus $3 / 4$ Bos indicus (462 kg at $30.6 \mathrm{mo}$ ) and for most of the breed types considered by Riera et al. [29]. The best indices of productive performance achieved with SS could be due to its protein sources of low ruminal degradability, such as hydrolyzed feather meal and cottonseed, which have been shown to favor a slow release of nitrogen $(\mathrm{N})$ in the rumen, increasing the efficiency of the microbiota to synthesize proteins [4]. Furthermore, it is known that a large part of the bypass protein fraction is degraded in the intestine to peptides and amino acids that promote muscle protein synthesis [14].

The literature supports the provision of a high-protein supplement in small amounts (catalytic) to stimulate the consumption and digestion of poor-quality forages [8], and several studies have found that Nitrogen supplementation improves the utilization of tropical grasses [4, 20], by achieving a greater extraction of energy from the forage [10]. The bypass fat derived from the cottonseed included in the strategic supplement-phase 2 could also improve the digestible protein/digestible energy ratio and consequently, the efficiency and quantity of microbial protein [38]. On the other hand, the addition of ionophores to the diet is known to increase the ruminal synthesis of propionic acid, while reducing that of butyric and acetic acids, as well as the production of methane and ammonium; increasing the digestibility of DM, CP and fiber which optimizes the use of forages [2, 37, 39]. In sum, the change in the ruminal fermentation pattern induced by the ionophore could also favor the ADG in the SS group. 
TABLE IV

Effects of type of suplementation on growth performance traits of bulls during fattening on grass

\begin{tabular}{|c|c|c|c|c|}
\hline \multirow{2}{*}{ Variable } & \multicolumn{2}{|c|}{$\begin{array}{c}\text { Suplementation } \\
\text { Type }\end{array}$} & \multirow{2}{*}{ SEM $^{1}$} & \multirow{2}{*}{$P$ value } \\
\hline & $\begin{array}{c}\text { MS } \\
(n=57)\end{array}$ & $\begin{array}{c}\text { SS } \\
(n=42)\end{array}$ & & \\
\hline Hip height, cm & 134.29 & 134.60 & 0.96 & 0.50 \\
\hline Fattening days & 236.63 & 198.33 & 3.10 & $<0.001$ \\
\hline $\begin{array}{l}\text { Chronological } \\
\text { age (mo.) }\end{array}$ & 30.83 & 29.39 & 0.32 & $<0.001$ \\
\hline $\begin{array}{l}\text { Final liveweight } \\
\text { on test, } \mathrm{kg}\end{array}$ & 474.42 & 498.23 & 8.16 & 0.02 \\
\hline $\begin{array}{l}\text { Shipping } \\
\text { liveweight, kg }\end{array}$ & 510.73 & 507.86 & 7.68 & 0.46 \\
\hline$A D G, g$ & 541.32 & 769.01 & 33.14 & $<0.001$ \\
\hline
\end{tabular}

MS: Mineral supplementation; SS: Strategic supplementation. ADG: Average daily gain. ${ }^{1}$ Standard Error of Mean.

\section{Effects of supplementation on carcass traits}

SS only favored $(P<0.05)$ carcass dressing percentage and physiological bone maturity $(P<0.001)$ (TABLE V). Carcasses from the SS group significantly dressed 1.5 percentage points more than their MS counterparts. Also, SS carcasses exhibited a greater youth of the skeleton (bone maturity) than those from the MS group $(P<0.001)$, which corresponds to their younger chronological age at harvest (TABLE IV). Without reaching statistical significance, carcasses from bulls with SS tended to have a more abundant fat cover $(P=0.07)$, thicker back fat $(P=0.08)$ and a larger REA $(P=0.09)$. The tendency to a more desirable fat cover in carcasses from the group SS could be due to the surpassing fat provided by the cottonseed, which is hydrolyzed in the small intestine and absorbed for the synthesis of body fat [19].

Riera [30] evaluated the response to fattening of grazing bulls in the same ranch, with a supplement based on $30 \%$ corn flour, $20 \%$ chicken litter, $15 \%$ rice polish, $10 \%$ soybean (Glycine max), $10 \%$ corn cob, $10 \%$ molasses and $5 \%$ of meat and bone meal. This author [30] indicated that bull carcasses derived from the supplemented group had a more desirable conformation and fat cover scores, as well as a slightly more abundant marbling $(P<0.05)$. Also, Jerez-Timaure and Huerta-Leidenz [17] reported a significant increase in carcass weight, younger bone maturity, better conformation scores, thicker backfat and lesser yellowish fat color in the supplemented group of bulls with respect to the control when testing a supplement based on $41 \%$ chicken manure, $50 \%$ rice polish, $6 \%$ molasses, $1.5 \%$ salt, $1.5 \%$ mineral mixture and $0.83 \%$ Rumensin $®$ ) [17]. The significant improvements in quality traits related to carcass finish observed with other types of supplementation in the same ranch $[17,29,30$,$] may also be due to the fact that in these previous$ trials, the experimental groups of bulls were not implanted.

\section{Effects of implant regimens on fattening performance}

The variables indicating productive performance did not vary with the implant regimen $(P>0.05)$. This was to be expected because, even under intensive fattening conditions no significant responses of bulls to the use of implants have been found [24, 25]. Perhaps it is due to the interference of the endogenous production of androgens. In fact, grass-fed bulls implanted with zeranol before puberty have grown $4.8 \%$ faster than non-implanted bulls [22]; but after puberty, the response to this nonsteroidal implant was inconsistent, presumably because the production of natural hormones would already be sufficient to promote growth [22].

TABLE V

Effects of type of suplementation on carcass traits

\begin{tabular}{|c|c|c|c|c|}
\hline \multirow{2}{*}{ Variable } & \multicolumn{2}{|c|}{$\begin{array}{c}\text { Suplementation } \\
\text { type }\end{array}$} & \multirow{2}{*}{ SEM } & \multirow{2}{*}{ P value } \\
\hline & $\begin{array}{c}\text { MS } \\
(n=57)\end{array}$ & $\begin{array}{c}\text { SS } \\
(n=42)\end{array}$ & & \\
\hline $\begin{array}{l}\text { Hot carcass weight, } \\
\text { kg }\end{array}$ & 294.16 & 300.21 & 4.76 & 0.71 \\
\hline Dressing, \% & 57.62 & 59.13 & 0.46 & 0.03 \\
\hline Conformation score & 3.57 & 3.62 & 0.18 & 0.24 \\
\hline Finish score ${ }^{b}$ & 3.63 & 3.05 & 0.16 & 0.42 \\
\hline Skeletal maturityc & 204.03 & 186.42 & 6.55 & $<0.001$ \\
\hline Lean maturiryc & 205.09 & 217.14 & 13.68 & 0.32 \\
\hline Overall maturityc & 205.44 & 201.90 & 9.25 & 0.47 \\
\hline Adipose maturityc & 2.93 & 2.92 & 0.07 & 0.77 \\
\hline Ribeye area, $\mathrm{cm}^{2}$ & 81.75 & 83.64 & 2.66 & 0.09 \\
\hline $\begin{array}{l}\text { Back fat thickness, } \\
\text { mm }\end{array}$ & 1.37 & 1.76 & 0.29 & 0.07 \\
\hline Marbling score & 5.85 & 5.86 & 0.09 & 0.71 \\
\hline Thigh width, cm & 61.30 & 62.37 & 0.88 & 0.41 \\
\hline Leg perimeter, cm & 120.87 & 120.86 & 1.24 & 0.79 \\
\hline $\begin{array}{l}\text { Length of pelvic limb, } \\
\qquad \mathrm{cm}\end{array}$ & 57.18 & 56.50 & 1.04 & 0.84 \\
\hline Carcass length, cm & 131.95 & 131.52 & 0.95 & 0.70 \\
\hline Thoracic depth, cm & 37.75 & 37.76 & 0.80 & 0.42 \\
\hline
\end{tabular}

MS: Mineral supplementation; SS, Strategic supplementation. SEM: Standard error of mean. ${ }^{\mathrm{a}}: 1$ = Extremely abundant, 2 = Abundant, $3=$ Medium, $4=$ Slight, $5=$ Scarce; ${ }^{b}: 1=$ Extremely abundant, $2=$ Abundant, $3=$ Medium, $4=$ Slight, 5 = Scarce; ${ }^{c}$ carcass within the 100 - 199 maturity range score represents the youngest group (100 is equal to A00 and 199 is equal to A99), 200 - 299: represent carcasses with intermediate, more advanced maturity ( 200 is equal to B00 and 299

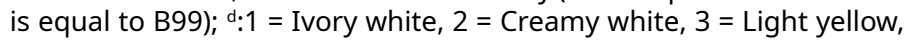
4 = Intense yellow, 5 = Orange; $: 1=$ Abundant, 2 = Moderate, $3=$ Small, 4 = Slight, 5 = Traces, 6 = Practically devoid. 
However, this explanation is not conclusive because bulls implanted with ATB or zeranol have presented lower levels of testosterone, reaching puberty 12 weeks later than not implanted counterparts [18]. Concentration and/or administration modes have shown to affect the bulls' response to the anabolic. The effectiveness of boldenone undecylenate on the final LW and ADG of fattened bulls has been reported [12] to be dose-dependent resulting significantly different from the control when the compound was injected at the highest dose [1 mililiter $\left.(\mathrm{mL}) \cdot 45 \mathrm{~kg}_{\text {of LW}}{ }^{-1}\right]$.

\section{Comparison of implant regimens for carcass traits}

Except for the thoracic depth, carcass traits did not vary significantly with the implant regimen. Carcasses of bulls implanted with Revalor-Ralgro exhibited deeper thoracic cavities $(P<0.01)$ [38.4 centimeters $(\mathrm{cm})], 4 \mathrm{~cm}$ more than those from the RalgroRalgro group $(37.08 \mathrm{~cm})$ with a standard error of the mean of $0.75 \mathrm{~cm}$ (values not presented in tabular form). The significance of this single finding is imponderable because no precedent was found in this regard; but it could suggest differences in muscle distribution in the forequarters.

\section{Carcass classification/grading of the experimental groups}

The chi square test did not detect significant differences $(P>0.05)$ between the category / grade frequencies for the different treatments. The TABLE VI shows the distribution of these frequencies. In general, the carcass sample had a poor grading performance in quality, indicated by: (a) predominance of category $B$, the second in quality for bull carcasses by Venezuelan standards; (b) $52 \%$ were "Bullocks" (bulls under 30 mo of age) that did not exceed the fourth USDA quality (Standard) grade; and (c) $48 \%$ were carcasses with B or more advanced maturity ('Bulls"), which are not eligible to be quality-graded in the USA. [35]. In compensation, the sample performed outstandingly in the U.S. Department of Agriculture (USDA) yield grade (USDA-YG), reaching the top two yield grades (USDA-YG 1 and USDA-YG 2) with superior yield capabilities in boneless lean cuts.

The results of the present trial agree with other reports reporting carcass grades for fed entire males where the "Bulls" of "Bullocks" with Bos indicus influence, hardly exceeded the USDA-Standard grade, but exhibited the top USDA yield grades [16, 36].

\section{TABLE VI}

Frequency distribution of carcass categories / grades according to supplementation type and implant regimen

\begin{tabular}{|c|c|c|c|c|}
\hline \multirow{2}{*}{$\begin{array}{c}\text { Carcass category/ } \\
\text { grade }\end{array}$} & \multicolumn{2}{|c|}{ Supplementation $^{1}$} & \multicolumn{2}{|c|}{ Implant regimen ${ }^{2}$} \\
\hline & MS n (\%) & SS n (\%) & RAL-RAL n (\%) & REV-RAL n (\%) \\
\hline \multicolumn{5}{|c|}{ Venezuelan carcass category 3} \\
\hline$A$ & $4(7.0)$ & $3(7.1)$ & $3(6.0)$ & $4(8.2)$ \\
\hline $\mathrm{B}$ & 33 (57.9) & $30(71.4)$ & $30(60.0)$ & $33(67.3)$ \\
\hline \multirow[t]{2}{*}{$\mathrm{C}$} & $20(35.1)$ & $9(21.4)$ & $17(34.0)$ & $12(24.5)$ \\
\hline & \multicolumn{2}{|c|}{$\chi^{2}=2.23 ; P=0.32$} & \multicolumn{2}{|c|}{$\chi^{2}=1.13 ; P=0.56$} \\
\hline \multicolumn{5}{|c|}{ USDA carcass quality grades ${ }^{4}$} \\
\hline High Standard & $4(7.0)$ & $4(9.5)$ & $4(8.0)$ & $4(8.2)$ \\
\hline Low Standard & $21(36.8)$ & $22(52.4)$ & $18(36.0)$ & $25(51.0)$ \\
\hline \multirow[t]{2}{*}{ Bull } & $32(56.1)$ & $16(38.0)$ & $28(56.0)$ & $20(40.8)$ \\
\hline & \multicolumn{2}{|c|}{$\chi^{2}=3.15 ; P=0.20$} & \multicolumn{2}{|c|}{$X^{2}=2.46 ; P=0.29$} \\
\hline \multicolumn{5}{|c|}{ USDA carcass yield grades ${ }^{5}$} \\
\hline 1 & $32(56.1)$ & $21(50.0)$ & $29(58.0)$ & $24(49.0)$ \\
\hline 2 & 25 (43.9) & $20(47.6)$ & $21(42.0)$ & $24(49.0)$ \\
\hline \multirow[t]{2}{*}{3} & $0(0.0)$ & $1(2.4)$ & $0(0.0)$ & $1(2.0)$ \\
\hline & \multicolumn{2}{|c|}{$\chi^{2}=1.66 ; P=0.43$} & \multicolumn{2}{|c|}{$\chi^{2}=1.60 ; P=0.45$} \\
\hline Total & 57 & 42 & 50 & 49 \\
\hline
\end{tabular}

${ }^{1}$ MS: Mineral supplementation; SS: Strategic supplementation; ${ }^{2}$ RAL-RAL: corresponds to double-dosis implant (72 mg) of Ralgro ${ }^{\circledR}$ at day 0 followed by a second dosis of $72 \mathrm{mg}$ of Ralgro ${ }^{\circledR}$ at day 90 . REV-RAL: corresponds to a first dosis of Revalor ${ }^{\circledR}$ at day 0 , followed by a second dosis (72 mg) of Ralgro ${ }^{\circledR}$ at day $90 ;{ }^{3} \mathrm{~A}$ and B Venezuelan carcass categories correspond to the second - and third-quality, respectively; ${ }^{4}$ Carcasses of bulls younger than 30 mo. of age and (or) exhibiting an A physiological maturity are designated in the "Bullock" class, USDA Standard quality grade corresponds to the fourth quality, for bullock carcasses; ${ }^{5}$ USDA yield grades (YG) are rated numerically, namely 1, 2, 3, 4, and 5; a YG 1 carcass is expected to have the highest proportion (> 53.5 \%) of boneless, closely-trimmed retail cuts, while a YG 5 carcass is expected to have the lowest proportion $(<44.3 \%)$ of boneless, closely-trimmed retail cuts. 


\section{CONCLUSIONS AND IMPLICATIONS}

Neither of the two implant regimes, despite their aggressiveness, affects the bull fattening performance, nor the commercially important carcass traits; therefore, its use is not justified under the conditions described here. Strategic supplementation proves to be a feasible practice to adopt in low-plains pastures to improve the fattening performance of bulls, but its impact on the overall quality of the carcass is expected to be marginal. From bulls thus implanted and supplemented, one can only expect very lean carcasses with high potential for cutout performance, but value adding will be extremely difficult if a yield grading system is not in place.

\section{FUNDING}

This research was funded by the Fondo Nacional de Ciencia, Innovación y Tecnología (FONACIT) de Venezuela and the Consejo de Desarrollo Científico y Humanístico de la Universidad del Zulia (CONDES-LUZ).

\section{ACKNOWLEDGMENTS}

The authors thank the staff of Hato Santa Luisa Co. for their support during the experimental trial and Matadero CentroOccidental (MINCO) for their valuable assistance during cattle harvesting and carcass evaluation.

\section{CONFLICT OF INTEREST}

The authors declare no conflict of interest.

\section{BIBLIOGRAPHIC REFERENCES}

[1] ARAUJO-FEBRES, O. Los promotores de crecimiento (implantes) en el ganado bovino. En: O. Araujo-Febres (Ed.). Tópicos especiales en la nutrición de rumiantes. Editorial Astro Data. Maracaibo. Pp. 167-193. 2014.

[2] ARAUJO-FEBRES, O.; FERNÁNDEZ, M. C. Efecto en novillos del Monensin y el nivel de fibra de la dieta sobre el consumo y la digestibilidad de la materia seca. Rev. Fac. Agron. (LUZ): 8: 143-153. 1991.

[3] ARIAS, R.; SANTA-CRUZ, C.; VELÁSQUEZ, A. Effect of High Potency Growth Implants on Average Daily Gain of GrassFattened Steers. Animals. 9: 587. 2019.

[4] BENTO, C. B. P.; AZEVEDO, A. C.; GOMES, D. I.; BATISTA, E. D.; RUFINO, L. M. A.; DETMANN, E.; MANTOVANI, H. C. Effect of protein supplementation on ruminal parameters and microbial community fingerprint of Nellore steers fed tropical forages. Animals. 10(1): 44-54. 2016.

[5] BYERS, F.M.; HUERTA-LEIDENZ, N.O.; RODRÍGUEZ-MATOS, C.; ORDOÑEZ, J.; AVELLANEDA, J.F.; STONE JR., G. Strategic nutritional management technologies for enhancing forage beef production in the tropical Venezuelan llanos. Arch. Latinoam. Prod. Anim. 5 (Suppl. 1): 177-179. 1997.

[6] CONNELL, J.; HUERTA-LEIDENZ, N.; RODAS-GONZALEZ, A. Respuesta a la tipificación en pie, suplementación y anabolizantes de becerros en crecimiento a sabana. Arch. Latinoam. Prod. Anim. 10(3): 156-163. 2002.
[7] COMISIÓN VENEZOLANA DE NORMAS INDUSTRIALES (COVENIN). Carne de Bovino. Definiciones generales. Norma venezolana COVENIN 435-82.C.D.U. 636.2:337.5. Caracas, Venezuela. 1982.

[8] DELCURTO, T; HESS, B; HUSTON, J; OLSON, K. Optimum supplementation strategies for beef cattle consuming low-quality roughages in the western United States. J Anim. Sci. 77 (Suppl E):1-16. 2000.

[9] DEPABLOS, L.; ORDÓÑEZ, J.; GODOY, S.; CHICCO, C.D. Suplementación mineral proteica de novillas a pastoreo en los Llanos Centrales de Venezuela. Zoot. Trop. 27(3): 249-262. 2009.

[10] DETMANN, E.; VALENTE, É. E. L.; BATISTA, E. D.; HUHTANEN, $P$. An evaluation of the performance and efficiency of nitrogen utilization in cattle fed tropical grass pastures with supplementation. Livest. Sci. 162: 141-153. 2014.

[11] DEVELOPMENT CORE TEAM R: A Language and Environment for Statistical Computing. Vienna, Austria: R Foundation for Statistical Computing. Version 3.6. https://bit.ly/3wFcoJK. 2020.

[12] ELSHARAWY, N.T.; AHMED, A.E.; HARIDY, M.; KASSAB, A.Y.; HAMDON, H.A. Safety range of Boldenone Undecylenate injection in beef bulls. Biosci. Res. 16(2): 1556-1564. 2019.

[13] FONDO NACIONAL DE CIENCIA, INNOVACIÓN Y TECNOLOGÍA(FONACIT). Código de Bioética y Bioseguridad. Ministerio del Poder Popular para Ciencia y Tecnología. 3ra. Ed. 63 pp. 2008.

[14] GARG, M.R. Role of bypass protein in feeding ruminants on crop residues based diets Review A.J.A.S. 11 (2):107-116. 1998.

[15] HUERTA-LEIDENZ, N.; ALVARADO, E.; MARTÍNEZ, L.; RINCÓN, E. Conformación, acabado y características biométricas de la canal de diferentes clases de bovinos sacrificados en el Estado Zulia. Rev. Fac. Agron. (LUZ). 5: 522-536. 1979.

[16] HUERTA-LEIDENZ, N.; RUIZ-FLORES, A.; VALERIOHERNANDEZ, J.; JEREZ-TIMAURE, N.; RODAS-GONZALEZ, A. Bullock carcass performance trends in Brahman and $F 1$ crosses fattened on tropical pastures. NACAMEH. 14 (1):1630. 2020.

[17] JEREZ-TIMAURE, N.; HUERTA-LEIDENZ, N. Effects of breed type and supplementation during grazing on carcass traits and meat quality of bulls fattened on improved savannah. Livest. Sci. 121, 219-226. 2009.

[18] JONES, S. J.; JOHNSON, R. D.; CALKINS, C. R.; DIKEMAN, $M$. Effects of trenbolone acetate on carcass characteristics and serum testosterone and cortisol concentrations in bulls and steers on different management and implant schemes. J Anim. Sci. 69:1363 - 1369. 1991.

[19] LABRUNE, H. J.; REINHARDT,C. D.; DIKEMAN, M,. E.; DROUILLARD, J.S. Effects of grain processing and dietary lipid source on performance, carcass characteristics, plasma fatty acids, and sensory properties of steaks from finishing cattle. J. Anim. Sci. 86:167-172. 2008. 
[20] LACHMANN, M.; BORTOLIN, E.; LOSADA, F.; ROMERO, M.; ARAUJO-FEBRES, O. Influencia del nivel de nitrógeno suplementado sobre el consumo, la digestibilidad y la ganancia de peso en novillos alimentados con heno de sorgo y alimento concentrado. Rev. Fac. Agron. (LUZ). 14: 665-671. 1997.

[21] LASCANO, C.E. Harry Stobbs Memorial Lecture: Managing the grazing resource for animal production in tropical America. Trop. Grassl. 25: 66-72. 1991.

[22] MACKENZIE, J.R. Effects of zeranol implant on behavior, growth rate, and carcass characteristics of Friesian bulls. New Zealand J. Exp. Agricul. 11: 225-229. 1983.

[23] MORON - FUENMAYOR, O.; ARAUJO-FEBRES, O.; RINCON - URDANETA, E. Efecto del implante, de la castración y mestizaje en toretes mestizos comerciales a pastoreo con suplementación. Rev. Fac. Agron. (LUZ). 9:49-62. 1992

[24] MORON-FUENMAYOR, O.; ARAUJO-FEBRES, O.; BRILLEMBOURG, D. Efecto de la condición sexual y del implante con ATB+17b-estradiol sobre el crecimiento de animales mestizos Santa Gertrudis. Rev. Fac. Agron. (LUZ). 11:81-87. 1994.

[25] MORÓN-FUENMAYOR, O.; ARAUJO-FEBRES, O.; HUERTALEIDENZ, N.; RINCÓN, E. Efecto de los agentes anabólicos sobre la ceba a corral y las caracteristicas de la canal de toretes mestizos Santa Gertrudis. Rev. Fac. Agron. (LUZ). 10: 325-342. 1993.

[26] NATIONAL RESEARCH COUNCIL (NRC). Nutrient Requirements of Beef Cattle,National Academies Press, Washington, D. C. Pp. 40-46. 2000.

[27] PLASSE, D.; FOSSI, H.; HOOGESTEIJN, R.; VERDE, O.; RODRÍGUEZ, M.C.; RODRÍGUEZ, R. Producción de vacas $F_{1}$ Bos taurus $\times$ Brahman apareadas con toros Brahman y de vacas Brahman con toros $\mathrm{F}_{1}$ Bos taurus $\mathrm{x}$ Brahman versus Brahman. 1. Pesos al nacer, destete, 18 meses y peso final. Livest. Res. Rural Develop. 12 (4): 14. 2000.

[28] REPÚBLICA DE VENEZUELA. Decreto Presidencial No. 1896. Ministerio de Agricultura y Cría. Gaceta Oficial de la República de Venezuela No 36.242. Caracas Venezuela. 4 pp. 1997.

[29] RIERA-SIGALA, T.J.; RODAS-GONZÁLEZ, A.; RODRÍGUEZMATOS, C.; AVELLANEDA, J.F.; HUERTA-LEIDENZ, N. Growth traits and carcass weights of purebred Brahman and F1 Brahman $x$ Bos taurus bulls raised and fattened semiintensively on improved savannah. Arch. Latinoam. Prod. Anim. 12: 66-72. 2004.
[30] RIERA, S.T. Crecimiento y características de toros de cinco tipos raciales y el efecto de tecnologías postmortem sobre la calidad de la carne. Universidad Rafael Urdaneta. Maracaibo, Venezuela. Tesis de Grado. 86 pp. 1994.

[31] RODAS-GONZÁLEZ, A.; HUERTA-LEIDENZ, N.; JEREZTIMAURE, N. Benchmarking Venezuelan quality grades for grass-fed cattle carcasses. Meat Muscle Biol. 1(1): 1-80. 2017.

[32] SMITH, J.K.; CHACÓN-MORENO, E.J.; JONGMAN, R.H.G.; WENTING, P.H.; LOEDEMAN, J.H. Effect of dyke construction on water dynamics in the flooding savannahs of Venezuela. Earth Surf. Process. Landforms. 31: 81-96. 2006.

[33] SMITH, Z. K.; JOHNSON, B.J. Mechanisms of steroidal implants to improve beef cattle growth: a review. J. Appl. Anim. Res. 48(1): 133-141. 2020.

[34] TEJOS, M.R.; MEJÍAS, N.; PÉREZ, Y.; AVELLANEDA, J.F. Manejo de pasturas y producción de carne en el llano bajo de Venezuela. 2005. IX Seminario de pastos y forrajes. Asociación Venezolana de Producción Animal. Pp. 171-181. En Línea: https://bit.ly/3xmJFtl. 13/11/2020

[35] UNITED STATES DEPARTMENT OF AGRICULTURE (USDA). Official United States standards for grades of carcass beef. 2017. Agricultural Marketing Service, Washington, D.C. On Line: https://bit.ly/3wyFM4I. 30/03/2021.

[36] VAZQUEZ-MENDOZA, O.V.; ARANDA-OSORIO, G.; HUERTABRAVO, M.; KHOLIF, A.E.; ELGHANDOUR, M.M.Y.; SALEM, A.Z.M.; MALDONADO-SIMÁN, E. Carcass and meat properties of six genotypes of young bulls finished under feedlot tropical conditions of Mexico. Anim. Prod. Sci. 57: 1186-119. 2017.

[37] VEDOVATTO, M.; PEREIRA, C. S; BELTRAME, J. A. M.; NETO, I. M. C.; BENTO, A. L. L.; MARTHA, G. O. D.; MORAIS, M. G.; FRANCO, G. L. Inclusion of concentrate and growth promoters' additives in sheep diets on intake, digestibility, degradability, ruminal variables and nitrogen balance. Rev. Mex. Cien. Pec. 11(1):132-152. 2020.

[38] WANAPAT, M; FOIKLANG, S.; ROWLINSON, P.; PILAJUN, $R$. Effect of carbohydrate sources and cotton seed meal in the concentrate: II. Feed intake, nutrient digestibility, rumen fermentation and microbial protein synthesis in beef cattle. Trop. Anim. Health Prod. 44: 35-42. 2012.

[39] WANG, L.M. Investigation of Alternatives to lonophore/ Antibiotic Management Strategies in Finishing Cattle and the Inherent Effect on Beef Quality and Shelf Life. University of Guelph, Guelph, Ontario, Canada. Thesis of Grade. 149 pp. 2019. 


\title{
Comportamiento animal y composición botánica de la dieta de ovinos apacentando estrella africana (Cynodon plectostachyus (L.) Pers.) en monocultivo y asociada con Leucaena leucocephala (Lam.) de Wit. y Guazuma ulmifolia (Lam.)
}

\author{
Animal behavior and botanical composition of the diet of the african ovine star (Cynodon \\ plectostachyus (L) Pers.) in monoculture and associated with Leucaena leucocephala (Lam.) \\ de Wit. and Guazuma ulmifolia (Lam.)
}

\author{
René Pinto-Ruiz , Angélica Anahí Pérez-Díaz ${ }^{2 *}$, David Hernández-Sánchez ${ }^{3}$, Francisco Guevara-Hernandez , \\ Gerardo Uriel-Trujillo ${ }^{4}$ y Pedro Cadena-Iñiguez ${ }^{5}$
}

\begin{abstract}
${ }^{1}$ Facultad de Ciencias Agronómicas, Universidad Autónoma de Chiapas (UNACH). Chiapas, México. ${ }^{2}$ Estudiante del programa de Maestría en Ciencias en Producción Agropecuaria Tropical, Universidad Autónoma de Chiapas (UNACH). Chiapas, México.

${ }^{3}$ Colegio de Posgraduados, Montecillo. México, México. ${ }^{4}$ Facultad de Medicina Veterinaria y Zootecnia, Universidad Autónoma de Chiapas, Universidad Autónoma de Chiapas (UNACH). Chiapas, México. ${ }^{-}$Instituto Nacional de Investigaciones Forestales Agrícolas y Pecuarias. México, México. *Correo electrónico: anny_chapa_93@hotmail.com
\end{abstract}

\section{RESUMEN}

Se realizó el presente estudio para conocer el comportamiento en pastoreo y la composición botánica de la dieta seleccionada por ovinos apacentando una pradera de "estrella africana" (Cynodon plectostachyus) en monocultivo y el mismo pasto asociado con Leucaena leucocephala y Guazuma ulmifolia, en dos épocas del año (a). Las variables obtenidas en un periodo de 12 horas (h) fueron: los tiempos de pastoreo, ramoneo, rumia y descanso bajo sol o bajo la sombra de los árboles, asimismo se obtuvo en un espacio de $24 \mathrm{~h}$, la frecuencia de orina y consumo de agua. Por otro lado, se midió la composición botánica de la dieta seleccionada por cada animal y la temperatura rectal de los ovinos apacentados en ambos tipos de praderas durante la época de sacas y de lluvias. Los resultados indicaron que el tiempo de pastoreo de los ovinos no fue modificado por el tipo de pradera en ambas estaciones del a. El tiempo de rumia fue mayor y el tiempo de descanso fue menor en los ovinos apacentando en la pradera arbolada. Se encontró que la temperatura corporal tomada por vía rectal disminuyó 0,25 y $0,38^{\circ} \mathrm{C}$ en la época seca y de lluvia, respectivamente, en relación a los animales que apacentaron en praderas en monocultivo. Los ovinos comieron más follaje arbóreo y bebieron más agua durante la época seca, asociado con mayor actividad de ramoneo. En conclusión, el sistema silvopastoril modifica favorablemente las actividades diarias de los ovinos en pastoreo y brinda mayor confort y bienestar a los animales.

Palabras clave: Conducta animal; dieta seleccionada; sistemas silvopastoriles; ovinos

\begin{abstract}
The present study was carried out to know the grazing behavior and the botanical composition of the diet selected by sheep grazing a meadow of "African star" (Cynodon plectostachyus) in monoculture and the same grass associated with Leucaena leucocephala and Guazuma ulmifolia, in two seasons of the year (yr). The variables obtained in a period of 12 hours (h) were: the times of grazing, browsing, rumination and rest under the sun or under the shade of the trees, also the frequency of urine and consumption was obtained in a space of $24 \mathrm{~h}$ of water. On the other hand, the botanical composition of the diet selected by each animal and the rectal temperature of the sheep grazed in both types of meadows during the sack and rain season were measured. The results indicated that the grazing time of the sheep was not modified by the type of pasture in both seasons of the yr. The rumination time was longer and the rest time was shorter in the sheep grazing in the wooded meadow. It was found that the body temperature taken by straight route decreased 0.25 and $0.38{ }^{\circ} \mathrm{C}$ in the dry and rainy season, respectively, in relation to the animals that grazed in monoculture meadows. Sheep ate more tree foliage and drank more water during the dry season, associated with higher browsing activity. In conclusion, the silvopastoral system favorably modifies the daily activities of grazing sheep and provides greater comfort and well-being to the animals.
\end{abstract}

Key words: Animal behavior; selected diet; silvopastoril systems; sheep 


\section{INTRODUCCIÓN}

La ganadería en el trópico seco del sureste de México se desarrolla bajo modelos de pastoreo, donde el consumo de gramíneas constituye la base de la alimentación de los animales $[27,28]$. En el sector campesino, la ovinocultura es parte integral de la estrategia de subsistencia socioeconómica y juega un papel central en la capitalización de esas familias pobres [20]. Los hatos ovinos (Ovis aries) se alimentan principalmente de recursos forrajeros pues su explotación es extensiva y se distribuyen en zonas marginadas [12]. Estas condiciones hacen necesaria la búsqueda de alternativas para mejorar la productividad del rebaño; ello significa la búsqueda de fuentes de alimentación más eficientes, de bajos costos y sostenibles en el uso de los recursos forrajeros.

Actualmente, en la región tropical de México existe interés en el desarrollo de sistemas de alimentación basados en sistemas silvopastoriles, en los cuales, los árboles forrajeros juegan un papel importante. Sin embargo, el manejo adecuado de los sistemas silvopastoriles depende mucho de la forma en que éstos son utilizados por los animales. Bajo estas condiciones, la integración de árboles con pastos resulta importante, pero hace complejo el sistema de producción debido a las interacciones planta-animal, ya que la presencia de arbóreas en las áreas de pastoreo puede hacer variar el comportamiento animal en respuesta a la sombra que proporcionan los árboles, a su estructura de copa, y a la cantidad y calidad del forraje disponible [37] en comparación con el tradicional pastoreo de praderas en monocultivo. Pocos son los estudios realizados con ovinos bajo estas circunstancias, por lo que el objetivo de este estudio fue conocer el comportamiento animal y la composición botánica de la dieta seleccionada por ovinos en apacentamiento de una pradera en monocultivo en comparación con pasturas en callejones.

\section{MATERIALES Y MÉTODOS}

\section{Localización del área de estudio}

La evaluación se realizó en el rancho La Trinidad, propiedad de un productor cooperante dedicado a la producción y comercialización de ganado ovino de registro. El rancho se localizó en el municipio Villaflores, al oeste del estado de Chiapas, México. Situándose entre los 16¹3'15"de LN, 93016'07" LO, con altitud promedio de 610 metros sobre el nivel del mar. El clima es cálido subhúmedo con lluvias en verano; temperatura media anual de $24,3^{\circ} \mathrm{C}$ y precipitación pluvial media anual de 1.209 milímetros ( $\mathrm{mm})$, distribuidas en verano, principalmente [10].

\section{Características de las praderas evaluadas}

La pradera silvopastoril consistió en la asociación de pastos Cynodon plectostachyus e Hyparrhenia ruffa con Leucaena leucocephala y Guazuma ulmifolia, bajo la modalidad silvopastoril conocida como pastura en callejones. Los árboles se encuentran sembrados en hileras sencillas y alternadas, orientadas de oriente a poniente, distancia entre hileras de tres metros $(\mathrm{m})$ y entre árboles de un $\mathrm{m}$. La altura de poda de los árboles fue 90 centímetros $(\mathrm{cm})$, con la finalidad de mantener disponible el material forrajero para el ramoneo de los animales. La edad de la pradera es de tres años (a) en una superficie de tres hectáreas (ha). La pradera de solo gramíneas consistió en un potrero establecido con pasto
C. plectostachyus, con cinco a de establecida y una superficie de cuatro ha.

Tanto en el sistema silvopastoril como en el de solo pasto se colocaron bebederos graduados para medir consumo de agua por los animales. Ambas praderas se manejaron bajo condiciones de temporal y sin fertilización.

\section{Características de los animales y su manejo}

Se utilizaron veinte ovinos machos de raza Pelibuey, con edad promedio de ocho meses (mes) y peso vivo de 24,6 $\pm 2,3$ kilogramos $(\mathrm{kg})$. Al inicio del experimento, los animales fueron desparasitados con Doramectina $\left(0,5\right.$ mililitros $(\mathrm{mL}) \cdot$ animal $\left.^{-1}\right)$ y vitaminados con Vitadel $\left(1,0 \mathrm{~mL} \cdot\right.$ animal $\left.^{-1}\right)$. En cada tratamiento (tipo de pradera) se asignaron diez ovinos. Los animales se marcaron con un número en el dorso para identificarlos. Cada cordero constituyó la unidad experimental (UP).

\section{Épocas de evaluación}

La conducta de los ovinos y composición de la dieta se evaluaron durante la época seca en los mes de marzo y abril, y para la época de lluvia fue en los mes de agosto y septiembre, ambas épocas del 2019.

\section{Variables evaluadas}

\section{Conducta animal diaria y diurna}

Para el caso de la conducta diaria de los animales, se contemplaron periodos de observación continua de los ovinos en pastoreo durante 24 horas (h) durante los días (d) de marzo-abril y agosto-septiembre. En lo que respecta a la evaluación de la conducta diurna, los ovinos fueron observados durante $12 \mathrm{~h} \cdot \mathrm{d}^{-1}(6: 00$ - 18:00 h) durante los d de marzo-abril y agosto-septiembre. En ambos casos, se observó la conducta de los animales a intervalos de 10 minutos (min) a lo largo de todo el período de evaluación, anotando la actividad que cada animal realizaba. Para no influir en la conducta natural de los ovinos en pastoreo, se observaron los animales a $10 \mathrm{~m}$ de distancia, aproximadamente.

Las actividades diarias observadas en los ovinos en pastoreo fueron: tiempo de pastoreo, tiempo de ramoneo, tiempo dedicado a la rumia y descanso, número de veces orinando, número de veces que bebieron agua, y consumo diario de agua.

Para el caso de las actividades diurnas, se evaluaron las mismas variables en condiciones de sombra y a pleno sol. Cabe señalar que los bebederos en ambos sistemas estuvieron bajo sombra.

Con la finalidad de conocer los efectos de la cobertura arbórea sobre el animal, se midió cada h la temperatura rectal (TR) de cada animal utilizando un termómetro de mercurio (Brannan $\AA$, modelo BRA44-820-0, Thermometers and Instrumentation, Inglaterra) colocado directamente en el recto del animal.

\section{Composición botánica de la dieta}

Para determinar la composición botánica de la dieta se utilizó la técnica de microhistología de heces. El muestreo de heces se realizó en cada animal y cada época del a. Las muestras de heces fueron tomadas directamente del recto del animal en dos momentos: al entrar y al salir el ovino de la pradera correspondiente. Se realizó el montaje de patrones y heces [19]. 
Una vez identificadas las especies forrajeras consumidas por los animales, se procesaron individualmente para realizar el montaje de laminillas de referencia (patrones de cada especie forrajera). Del mismo modo se montaron laminillas temporales de las especies forrajeras presentes en las muestras fecales. Observando al microscopio (Velab®, modelo Ve-B50, Texas, Estados Unidos de América) las laminillas de referencia y las temporales, se realizó la descripción histológica para identificar estructuras anatómicas de las especies vegetales colectadas, tales como los tricomas, los cuales fueron descritos en su forma y tamaño.

\section{Diseño experimental y análisis estadístico}

Las variables de conducta diaria y diurna, así como la TR fueron analizadas mediante el procedimiento GLM de SAS [30]. Para ello, se utilizó un diseño experimental completamente al azar con dos tratamientos (tipo de pradera) y diez repeticiones por tratamiento (animales). Las medias de tratamientos fueron comparadas mediante la prueba de Tukey $(P<0,05)$. El análisis de los datos se realizó para cada época del a por separado.

\section{RESULTADOS Y DISCUSIÓN}

En la TABLA I se presentan los resultados del análisis estadístico realizado a las actividades de conducta de los ovinos pastoreando las praderas con solo C. plectostachyus y C. plectostachyus asociado con L. leucocephala y G. ulmifolia. Estos resultados muestran que la actividad de pastoreo fue similar $(P<0,05)$ en ambos tipos de praderas para cada época del a. Se aprecian diferencias estadísticas $(P<0,05)$ en el tiempo dedicado a descansar, ya que los ovinos pastoreando $C$. plectostachyus en monocultivo estuvieron descansando por más tiempo que aquellos que pastorearon la pradera asociada del pasto con arbóreas forrajeras, tanto en la época de secas como de lluvias. Sin embargo, el tiempo dedicado a la rumia fue mayor $(P<0,05)$ en los ovinos pastoreando la pradera asociada en ambas épocas del a. Del mismo modo, el tiempo dedicado al ramoneo fue mayor $(P<0,05)$ en ovinos que pastorearon la pradera del sistema silvopastoril durante la época de secas comparado con el mismo tipo de pradera durante la época de lluvias.

Los datos indican que los animales dedicaron más tiempo al pastoreo en la época seca $(8,93 \mathrm{~h})$ que durante el periodo de
Iluvia (6,68 h), lo cual podría explicarse por la disminución en la disponibilidad de biomasa forrajera en la estación seca del año, producto de falta de humedad, edad del pasto y al incremento de la estacionalidad de la producción de la biomasa [36], lo cual lleva al animal a emplear más tiempo al pastoreo para satisfacer sus necesidades de materia seca (MS) [25], lo que coincide con Solfanelli [31], quién evaluó el consumo de bovinos (Bos taurus) en pastoreo durante un a y reportó diferencias de hasta 100 min dedicados al pastoreo entre las épocas de seca y lluvia, sustituyendo que la falta de forraje en la época seca obliga a los animales a dedicar más tiempo al pastoreo en el intento de cubrir los requerimientos de MS debido, principalmente, al menor tamaño del bocado. Por otro lado, los promedios del tiempo dedicado al pastoreo fluctuaron entre 6,62 a $9,08 \mathrm{~h}$, tiempos que se encuentran dentro del rango reportado para rumiantes [25, 37, 40].

El tiempo dedicado al pastoreo por los ovinos durante la época lluviosa en ambos tipos de praderas $(6,68 \mathrm{~h})$ fueron similares a los reportados por Zuccari y col. [40] en ovinos (6,20 h) para dos regímenes de pastoreo durante el verano. Por otro lado, los valores promedio del tiempo dedicado al pastoreo durante la época seca en ambos tipos de praderas (8,93 h) fueron mayores, aunque similares, a los reportados en otros trabajos con bovinos $[9,25,26]$.

La similitud entre los tratamientos indica que el uso de arbóreas en la pradera no influyó sobre el tiempo dedicado al pastoreo por los ovinos. Sin embargo, algunos trabajos reportan mayor tiempo de pastoreo en praderas con arbóreas $[22,24]$ ya que, los animales modifican sus estrategias de pastoreo en respuesta a presencia de árboles, así como a cambios en la fenología y disponibilidad del pasto presente bajo dosel arbóreo. Esta conducta es de suma importancia ya que al no modificarse el tiempo de pastoreo en ambos tipos de pradera se logra maximizar el consumo de pasto por el animal [35]. Adicionalmente, se debe considerar el tiempo que los animales dedican al ramoneo en la pradera asociada, lo cual suma mayor tiempo dedicado al consumo de forraje por parte de los ovinos.

La no diferencia entre ambos tipos de praderas obtenidas en el presente trabajo para el tiempo dedicado al pastoreo por los ovinos dentro de cada época del año $(P>0,05)$ se debe a los cambios en la disponibilidad del pasto basal ocasionado por la

TABLA I

Conducta de los ovinos pastoreando estrella africana (Cynodon plestotachyus) en monocultivo y asociada con Leucaena leucocephala y Guazuma ulmifolia durante dos épocas del año

\begin{tabular}{|c|c|c|c|c|c|c|}
\hline \multirow[b]{2}{*}{ Variables } & \multicolumn{3}{|c|}{ Época seca } & \multicolumn{3}{|c|}{ Época de lluvias } \\
\hline & $\begin{array}{c}\text { Pradera asociada } \\
{\text { horas } \cdot \text { día }^{-1} \cdot \text { animal }^{-1}}\end{array}$ & $\begin{array}{c}\text { Pradera solo } \\
\text { pasto }\end{array}$ & EEM & 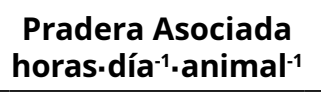 & $\begin{array}{c}\text { Pradera solo } \\
\text { pasto }\end{array}$ & EEM \\
\hline Pastoreo & $8,78^{a}$ & $9,08^{a}$ & 0,10 & $6,62^{\mathrm{a}}$ & $6,75^{\mathrm{a}}$ & 0,14 \\
\hline Descanso & $7,28^{b}$ & $9,55^{a}$ & 0,44 & $7,55^{b}$ & $11,63^{a}$ & 0,69 \\
\hline Rumia & $6,08^{a}$ & $5,37^{b}$ & 0,14 & $7,28^{\mathrm{a}}$ & $5,57^{\mathrm{b}}$ & 0,33 \\
\hline Ramoneo & $2,40^{a}$ & -- & & $1,85^{\mathrm{b}}$ & -- & 0,13 \\
\hline
\end{tabular}

Letras distintas en la misma hilera dentro de cada época indican diferencias estadísticas $(\mathrm{P}<0,05)$; EEM = Error estándar de la media. 
poda en los árboles, existen otras variables que puedan afectar el tiempo dedicado al pastoreo, las cuales son el microclima generado por las copas de los árboles [2].

Para los tiempos de descanso y rumia, los animales de ambos tratamientos dedicaron mayor tiempo a ambas actividades durante las lluvias $(9,59$ y $6,42 \mathrm{~h}$, respectivamente) que durante la época seca ( 8,54 y $5,72 \mathrm{~h}$, respectivamente), debido a que dedicaron más tiempo al pastoreo (6,68 y 8,3 h para le época de lluvia y seca, respectivamente).

El tiempo en que los animales no están comiendo, rumiando o ingiriendo agua, es definido como ocio o descanso. La tendencia a mayor tiempo dedicado al descanso $(P<0,05)$ fue para la pradera en monocultivo, lo cual coincide con lo reportado por Espinoza y col. [9] en bovinos pastoreando praderas en monocultivo y asociadas en sistemas silvopastoriles. Sin embargo, el tiempo promedio de descanso encontrado en ambos tipos de praderas es mayor que el promedio reportado en trabajos anteriores, previamente citados.

El tiempo de pastoreo que dedicaron los ovinos $(P<0,05)$ en la pradera con monocultivo presentaron diferencias significativas en con comparación con los animales asignados a la pradera silvopastoril, compensado con mayor tiempo dedicado a la rumia $(P<0,05)$. Al respecto, Arnold y Dudzinsky [4] mencionan que después del pastoreo, la actividad que mayor tiempo dedican los rumiantes es a la rumia (5 a $9 \mathrm{~h}$ ).

El tiempo que los ovinos dedicaron a la rumia mostró la misma tendencia que otras investigaciones han reportado Espinoza y col. [9] con mayores tiempos de rumia en los animales que pastorean praderas silvopastoriles en comparación con animales pastando praderas en monocultivo.

Al considerar la importancia de las diferentes actividades realizadas por los ovinos pastoreando en monocultivo de gramíneas y en sistemas silvopastoriles, los animales dedican el 60 y $55 \%$ del tiempo al pastoreo y a la rumia, respectivamente, lo cual coincide con lo reportado por Sotckdale y King [34] y Hodgson [15].

La actividad de ramoneo consiste en la remoción de hojas y tallos tiernos ricos en proteína directamente de la planta [6]. En este sentido, el tiempo dedicado al ramoneo fue mayor en la época seca (TABLA I), este comportamiento pudo deberse a que en esta época existió menor disponibilidad y baja calidad del pasto, lo que motivó a los animales a aumentar el tiempo del ramoneo para satisfacer sus necesidades alimenticias. Este comportamiento también se ha reportado con bovinos [26]. En este trabajo, el tiempo dedicado al ramoneo fue menor (1,48 vs 0,38 h, para la época seca y lluviosa, respectivamente) a las observadas en el presente estudio $(2,40$ vs 1,85 h, para las épocas de secas y lluviosas, respectivamente). Lo anterior explica la naturaleza de los pequeños rumiantes de ramonear más que los bovinos [18]. Respuestas similares en vaquillas fueron reportaras en los trabajos de Espinoza y col. [9].

El tiempo dedicado al ramoneo representó el 10 y $7,7 \%$ del total de las actividades diarias de los ovino en pastoreo para las épocas seca y lluviosa, respectivamente. Analizando la misma variable, Betancourt y col. [6] reportaron que las vacas dedicaron 7,75 \% del tiempo total de pastoreo al ramoneo de especies arbóreas, lo cual fue similar al tiempo que dedicaron los ovinos al ramoneo en la presente investigación. Sin embargo, los valores promedios reportados por Espinoza y col. [9] fueron menores (2\%) para vaquillas pastoreando en bosque natural.

Cabe señalar que, aunque no existieron diferencias $(P>0.05)$ entre el tiempo de pastoreo en las praderas en monocultivo y asociadas, numéricamente fue mayor en animales que apacentaron en praderas asociadas, así mismo, estos animales distribuyeron el tiempo en realizar otras actividades como ramoneo (27\%). Este resultado fue similar al encontrado en bovinos en experimentos similares (25\%) [28].

El mayor tiempo dedicado por los ovinos al ramoneo de las arbóreas $(P<0,05)$ durante la época seca puede estar relacionado con el forraje seco del estrato herbáceo presente en la pradera [26], ya que los animales tienen preferencia por la biomasa verde durante la época seca [38]. En este sentido, los árboles en los potreros proporcionan forraje verde y de buena calidad en la época seca, cuando la biomasa disponible de los pastos es de baja calidad [14].

En lo que respecta a la conducta de las actividades diurna de los ovinos pastoreando ambos tipos de praderas por $12 \mathrm{~h}$ durante la época seca (TABLA II), reveló que el pastoreo como el ramoneo se realizaron indistintamente $(P<0,05)$ tanto en condiciones de sol como de sombra. Sin embargo, el tiempo dedicado por los ovinos a descanso y rumia fue mayor bajo la sombra que a pleno

TABLA II

Conducta diurna de los ovinos pastoreando por 12 horas estrella africana (Cynodon Plestostachyus) en monocultivo y asociada con Leucaena leucocephala y Guazuma ulmifolia, durante dos épocas del año

\begin{tabular}{|c|c|c|c|c|c|c|}
\hline \multirow{2}{*}{$\begin{array}{c}\text { Variables } \\
\text { (horas diurnas) }\end{array}$} & \multicolumn{3}{|c|}{ Época seca } & \multicolumn{3}{|c|}{ Época de lluvias } \\
\hline & Sol & Sombra & EEM & Sol & Sombra & EEM \\
\hline Pastoreo & $3,40^{\mathrm{a}}$ & $3,47^{a}$ & 0,09 & $0,67^{b}$ & $3,60^{a}$ & 0,49 \\
\hline Descanso & $0,13^{b}$ & $1,88^{a}$ & 0,31 & $0,30^{\mathrm{b}}$ & $2,40^{a}$ & 0,35 \\
\hline Rumia & $0,30^{\mathrm{b}}$ & $1,23^{a}$ & 0,17 & $0,35^{b}$ & $2,83^{a}$ & 0,41 \\
\hline Ramoneo & $0,65^{a}$ & $0,93^{a}$ & 0,10 & $1,52^{\mathrm{a}}$ & $0,48^{b}$ & 0,17 \\
\hline
\end{tabular}

Letras distintas en la misma hilera dentro de cada época indican diferencias estadísticas $(P<0,05)$; EEM = Error estándar de la media. 
sol $(P<0,05)$. Por otro lado, en la época lluviosa, los animales dedicaron mayor tiempo $(P<0,05)$ a pastorear, descansar y rumiar bajo la sombra, mientras que el ramoneo fue realizado por más tiempo a pleno sol $(P<0,05)$.

La presencia de árboles en los potreros crea un microclima con efectos positivos en la conducta del animal, lo cual explica el mayor tiempo que los ovinos dedicaron al descanso y rumia bajo la sombra de la pradera con árboles en ambas épocas del año, lo cual puede explicarse debido a que los animales prefieren realizar las actividades de descanso y rumia en condiciones de tranquilidad y confort $[23,24]$.

El tiempo diurno dedicado al pastoreo presentó una inferencia de $28 \%$ bajo sol y $28.9 \%$ bajo sombra, mientras que el tiempo de descanso y rumia a pleno sol fue de 3,6 y 26,0 \% bajo sombra, similares a los reportados anteriormente para ovinos pastoreando $P$. saman y G. ulmifolia durante época seca [39]. Por otro lado, los animales que estuvieron mayor actividad bajo sombra que en las praderas sin presencia de cobertura vegetal $(7,51 \mathrm{~h}$ y $5,3 \mathrm{~h}$, respectivamente), lo cual confirma la importancia del dosel arbóreo como aportador de sombra para los animales [41].

La composición botánica de la dieta de los ovinos (TABLA III) fue más variada debido a la mayor diversidad de especies forrajeras en la pradera con árboles; sin embargo, la proporción de gramíneas en la dieta fue siempre más alta, tanto en la época de secas como de lluvias, en una relación de 81,77 vs 18,20 \%, entre el forraje proveniente de las gramíneas y de las arbóreas, respectivamente. La presencia de forraje proveniente de leñosas en la dieta de los ovinos durante las dos épocas del año podría deberse a que el follaje de estas especies está disponible durante todo el año y es de alto valor nutricional $[11,40]$. Dentro de las arbóreas, $L$. leucocephala fue la especie forrajera más ingerida por ovinos con 14.74 y $10.06 \%$ en la época seca y lluvia, respectivamente, en comparación con G. ulmifolia (5.36 y $6.25 \%$ en la época seca y lluvia, respectivamente).

Se ha documentado que incluir follaje arbóreo mejora la calidad nutricional de la dieta consumida por los animales en pastoreo, en esta investigación, el $20 \%$ de la dieta estuvo constituida por follaje de las arbóreas en la época seca y 16,25 \% en la época de lluvias. Estos resultados son similares a los reportados en otros trabajos con bovinos, en los cuales, el 16,1\% de la dieta estaba compuesta por follaje arbóreo [7], 18,1 \% cuando los bovinos pastoreaban en acahuales [29] y 26,5 \% cuando toretes pastorearon en vegetación natural [13].

En lo que respecta al pastoreo en áreas de vegetación secundaria (acahuales), las arbustivas son parte importante de la composición de la dieta en la época de menor precipitación, y se estima que más del $60 \%$ de la materia seca consumida por los bovinos proviene de arbustivas que se establecen en los acahuales [13, 32]. Esta respuesta puede estar asociada a que las arbóreas, a diferencia de las gramíneas, ofrecen material verde durante la época seca que es consumido por los animales [14]. Asimismo, se ha determinado un incremento en el consumo de follaje de los arbustos a medida que el pasto comienza a madurar [7].

La selección entre las gramíneas y las arbóreas por los ovinos puede asociarse con la preferencia o palatabilidad del recurso forrajero o con la abundancia de las especies forrajeras en la pradera, así como con la carga animal y el tiempo de pastoreo empleados. Con relación a la gramínea C. plestostachyus, los resultados indican la presencia de Hyparrhenia ruffa, lo que indica la selectividad de los animales cuando tienen la posibilidad de seleccionar el forraje ofrecido.

Aunque la técnica microhistológica es útil para determinar las diferentes especies vegetales que componen la dieta, la información proporcionada mediante esta técnica no es suficiente para estimar el consumo de las diferentes plantas forrajeras presentes en una pradera. Los resultados resaltan la importancia de promover mayor diversidad vegetal en las áreas de pastoreo. Esto permitirá a los animales variar su dieta y mejorar la calidad de la misma resultando en un mejor comportamiento animal.

El análisis estadístico de la influencia del tipo de pradera en la temperatura rectal de los ovinos durante la época seca (TABLA IV) indica que no hubo diferencias entre los ovinos asignados a la pradera en monocultivo y aquellos que pastorearon la pradera con estrella africana asociada con arbóreas, mientras que, durante la época de lluvias, la temperatura rectal fue mayor $(P<0,05)$ en los ovinos pastoreando la pradera sin árboles.

El rango de temperatura rectal de los ovinos en pastoreo $(38,41 \mathrm{a}$ $\left.39,61^{\circ} \mathrm{C}\right)$ estuvo dentro de los límites fisiológicos adecuados $(37,8$ a $40,0^{\circ} \mathrm{C}$ ) reportados por Arias y col. [3] aunque el promedio de TR de los ovinos pastoreando la pradera en monocultivo durante la época lluviosa superó ligeramente este rango. La TR promedio de los ovinos fue de $38,5^{\circ} \mathrm{C}$ para ambos tipos de praderas durante

TABLA III

Composición botánica (\%) de la dieta seleccionada por ovinos pastoreando estrella africana (Cynodon plestostachyus) en monocultivo y asociada con Leucaena leucocephala y Guazuma ulmifolia, durante dos épocas del año

\begin{tabular}{cccccc}
\hline \multirow{2}{*}{ Nombre Común } & Nombre Científico & \multicolumn{2}{c}{ Época seca } & \multicolumn{2}{c}{ Época de Iluvias } \\
\cline { 3 - 5 } & & $\begin{array}{c}\text { Pradera } \\
\text { asociada }\end{array}$ & $\begin{array}{c}\text { Pradera } \\
\text { solo pasto }\end{array}$ & $\begin{array}{c}\text { Pradera } \\
\text { asociada }\end{array}$ & $\begin{array}{c}\text { Pradera } \\
\text { solo pasto }\end{array}$ \\
\hline Estrella Africana & Cynodon plestostachyus & 76,04 & 100 & 73,06 & 93,24 \\
Jaragua & Hyparrhenia ruffa & 3,84 & 10,60 & 6,75 \\
Leucaena & Leucaena leucocephala & 14,74 & 10,06 & 6,25 \\
\hline
\end{tabular}


TABLA IV

Temperatura rectal (TR) de ovinos pastoreando estrella africana (Cynodon plestostachyus) en monocultivo y asociada con Leucaena leucocephala y Guazuma ulmifolia durante dos épocas del año

\begin{tabular}{ccccccc}
\hline \multirow{2}{*}{ Variables } & \multicolumn{3}{c}{ Época seca } & \multicolumn{3}{c}{ Época de lluvias } \\
\cline { 2 - 7 } & $\begin{array}{c}\text { Pradera } \\
\text { Asociada }\end{array}$ & $\begin{array}{c}\text { Pradera } \\
\text { solo pasto }\end{array}$ & EEM & $\begin{array}{c}\text { Pradera } \\
\text { Asociada }\end{array}$ & $\begin{array}{c}\text { Pradera } \\
\text { solo pasto }\end{array}$ & EEM \\
\hline TR & $38,41^{\mathrm{a}}$ & $38,66^{\mathrm{a}}$ & 0,10 & $39,23^{\mathrm{b}}$ & $39,61^{\mathrm{b}}$ & 0,08 \\
\hline
\end{tabular}

Letras distintas en la misma hilera dentro de época indican diferencias estadísticamente significativas $(P<0,05)$; TR $=$ Temperatura rectal en grados Celsius; EEM = Error estándar de la media

la época de seca, siendo ligeramente inferior a la TR promedio reportada por Alzina y col. [1] en bovinos pastoreando en la zona oriente de Yucatán durante la misma época del año (TR de $39,4^{\circ} \mathrm{C}$ ), pero fue similar a la reportada por Betancourt y col. [6] en vacas pastoreando potreros con baja cobertura arbórea durante la época de sequía (TR de $38,4^{\circ} \mathrm{C}$ ).

En este trabajo no se encontraron diferencias $(P>0,05)$ para la TR de los ovinos que pastorearon ambos tipos de praderas durante la época seca. Estos resultados contrastan con los obtenidos por Betancourt y col. [6] quienes reportaron diferencias significativas en la TR a favor de las vacas que pastorearon la cobertura arbórea. Por otro lado, la TR de los ovinos que pastorearon bajo sombra de los árboles fue mayor $(\mathrm{P}<0,05)$ durante la época lluviosa, lo cual pudo estar asociado a mayor humedad ambiental (79,95 vs 63,53 \% para las épocas de lluvias y secas, respectivamente). En este sentido, $70 \%$ de humedad ambiental es considerada aceptable para los ovinos, siempre y cuando la temperatura ambiental esté dentro de la zona termoneutral $\left(10\right.$ a $27^{\circ} \mathrm{C}$ [17]. Se sabe que la relación entre la temperatura y humedad ambiental son importantes en al balance calórico del animal [21].

En este trabajo, la temperatura ambiental en las praderas fue: $26,36^{\circ} \mathrm{C}$ en la época lluviosa y $26,00^{\circ} \mathrm{C}$ en la época seca. Durante la época de lluvias, la TR fue menor $(P<0,05)$ fue menor en los ovinos pastoreando la pradera asociada $\left(39,23{ }^{\circ} \mathrm{C}\right)$, comparado con aquellos animales que pastorearon la pradera de solo pasto $\left(39,61^{\circ} \mathrm{C}\right)$. Estas diferencias pueden asociarse con la influencia de la cobertura arbórea que pudo disminuir la TR en los animales creando un ambiente favorable para los ovinos [5].
Lo anterior es importante ya que en condiciones de estrés calórico el consumo de pasto disminuye [33] lo cual es más acentuado al disminuir del tiempo dedicado al pastoreo como sucedió en este trabajo. Sin embargo, la TR de los ovinos pastoreando en el sistema silvopastoril mostró tendencia a ser menor en ambas épocas del año comparado con la TR de los ovinos pastoreando la pradera en monocultivo. Esto puede explicarse por al hecho de que la presencia de árboles en la pradera tiene alto potencial para disminuir el estrés calórico en los animales, Mahecha y col. [16] y Souza y col. [33] aseguran que los árboles, a través de la sombra, contrarrestan la intensidad de los factores climáticos, pues interfieren parcialmente el paso de la radiación solar hacia la superficie corporal del animal, disminuyendo el estrés térmico y creando condiciones de confort.

En cuanto a la influencia del tipo de pradera sobre las conductas de los ovinos asociadas al clima, los resultados revelan promedios mayores $(P<0,05)$ en la frecuencia de evacuación de orina $(F E O)$, frecuencia en beber agua (FBA) y consumo diario de agua (CTA) en los ovinos pastoreando la pradera en monocultivo durante la época seca (TABLA V). Asimismo, hubo diferencias significativas $(P<0,05)$ en FBA en los ovinos pastoreando la pradera en monocultivo durante la época de lluvias. De este modo, los ovinos orinan más veces, acceden a la fuente de agua y consumen más agua durante la temporada de secas que durante la estación lluviosa (32,15 vs 29,53 veces; 7,40 vs 2,57 veces y 5,12 vs 0,56 litros (L), respectivamente). Arnold y Dudzinsky [4] indican que, además de los factores ambientales, el tipo de forraje y la distribución de la fuente de agua influyen en la frecuencia con que los animales toman agua. Sin embargo, los resultados del presente estudio se asocian

TABLA V

Actividades diarias de ovinos pastoreando estrella africana (Cynodon Plestostachyus) en monocultivo y asociada con Leucaena leucocephala y Guazuma Ulmifolia, en dos ëpocas a lo largo del año

\begin{tabular}{ccccccc}
\hline & \multicolumn{3}{c}{ Seca } & & \multicolumn{2}{c}{ Lluvia } \\
\cline { 2 - 6 } Variables & $\begin{array}{c}\text { Pradera } \\
\text { Asociada }\end{array}$ & $\begin{array}{c}\text { Pradera } \\
\text { solo pasto }\end{array}$ & EEM & $\begin{array}{c}\text { Pradera } \\
\text { Asociada }\end{array}$ & $\begin{array}{c}\text { Pradera } \\
\text { solo pasto }\end{array}$ & EEM \\
\hline FDO & $30,50^{\mathrm{b}}$ & $33,80^{\mathrm{a}}$ & 0,40 & $28,71^{\mathrm{a}}$ & $30,36^{\mathrm{a}}$ & 0,10 \\
FBA & $6,10^{\mathrm{b}}$ & $8,69^{\mathrm{a}}$ & 0,44 & $1,14^{\mathrm{b}}$ & $4,07^{\mathrm{a}}$ & 0,14 \\
$\begin{array}{c}\text { CTA, } \\
\text { litros.animal }\end{array}$ & 4, dia $^{-1}$ & $5,87^{\mathrm{b}}$ & 0,14 & $0,28^{\mathrm{a}}$ & $0,99^{\mathrm{a}}$ & 0,14 \\
\hline
\end{tabular}

Letras distintas en la misma hilera dentro de cada época indican diferencias estadísticamente significativas $(P<0,05)$; FDO = Frecuencia de orinar; FBA = Frecuencia de beber agua; $C T A=$ Consumo total de agua; EEM = Error estándar de la media. 
más a la condición del forraje, ya que la temperatura ambiente durante el estudio fue muy similar en ambas épocas del a (26,36 y $26,00^{\circ} \mathrm{C}$ para la época seca y lluviosa, respectivamente).

Lo ocurrido en la conducta diaria de los ovinos en la época seca está asociada a los beneficios de confort que los árboles de la pradera asociada ofrecen al animal y no a la temperatura ambiente o a la calidad del forraje, pues ésta fue similar en ambos tipos de praderas. De este modo, la presencia de árboles de sombra puede reducir la pérdida de líquidos corporales que provoca la radiación solar en los ovinos, contribuyendo a disminuir los requerimientos de agua de los animales. Estudios previos han reportado mayores consumos de agua durante los periodos calurosos por mayores pérdidas de líquidos corporales comparado con menor consumo de agua durante los periodos fríos y húmedos [8].

Durante la época de lluvias los ovinos pastoreando la pradera en monocultivo fueron más veces a tomar agua $(P<0,05)$, sin embargo, la cantidad de agua ingerida en cada toma fue moderada ya que el consumo total de agua diariamente por los ovinos fue similar entre ambos tratamientos $(P<0,05)$. Por tanto, la presencia de árboles en los potreros minimiza el consumo de agua y maximiza las actividades diarias de los ovinos.

\section{CONCLUSIONES}

Los resultados indican que el tiempo que los ovinos dedican al pastoreo no es una actividad animal que sea modificada por la cobertura arbórea presente en el sistema silvopastoril conformado por Cynodon plectostachyus en asociación con Leucaena leucocephala y Guazuma ulmifolia, aun cuando el tiempo de descanso y de rumia sean menores en las áreas de pastoreo arboladas, comparado con el pastoreo de praderas en monocultivo a pleno sol. Esta conducta de los ovinos puede asociarse al confort proporcionado por la sombra de los árboles, sobre todo en la época del año de mayor temperatura y humedad ambiental (estación lluviosa), en la cual la temperatura rectal es menor en los ovinos que pastorean en praderas asociadas.

El estudio de la composición de la dieta muestra que los ovinos comieron más follaje arbóreo durante la época seca en comparación con el consumo de arbóreas durante la época de lluvias, lo cual pudo estar asociado a mayor tiempo dedicado al ramoneo en esta época del año.

Finalmente, la mayor frecuencia en orinar durante la época seca debe relacionarse con mayor consumo de agua por pérdidas de agua corporal durante la época seca en los ovinos pastoreando la pradera en monocultivo, mientras que la menor frecuencia de la actividad de orinar en los ovinos que pastorearon la pradera asociada puede deberse a condiciones de confort ambiental proporcionado por la sombra de los árboles en el sistema silvopastoril.

\section{REFERENCIAS BIBLIOGRÁFICAS}

[1] ALZINA-LÓPEZ, A.; FARFÁN-ESCALANTE, J. C.; VALENCIAHEREDIA, E.; YOKOYAMA-KANO, J. Condición ambiental y su efecto en la temperatura rectal y frecuencia respiratoria en bovinos cruzados (Bos taurus $x$ Bos indicus) del estado de Yucatán, México. Rev. Biomed. 12 (2):112-121. 2001.
[2] AMAYA, G.Y.; CABALLERO, C.P.; LUNA, R. E.; SÁNCHEZ, M. F.; MANZANILLA, Q. G.; VILLALÓN, M.H. Evaluación del microclima en un sistema silvopastoril en Montemorelos, Nuevo León, México. Recursos Genéticos Forestales. Forest. Verac. 21 (1):19-22. 2019.

[3] ARIAS, R.A.; MADER, T. L.; ESCOBAR, P. C. Factores climáticos que afectan el desempeño productivo del ganado bovino de carne y leche. Temuco, Chile. Arch. Med. Vet. 40 (1): 7-22. 2008.

[4] ARNOLD, G. W.; DUDZINSKI, M. L. Ethology of free-ranging domestic animals. In: Arnold, G.W.; Dudzinski, M.L. (Eds). Developments in animal and veterinary sciences. Elsevier/ North-Holland Amsterdam. New York. Pp 179-192. 1978

[5] BARRAGÁN, H. W.; MAHECHA, L. L.; CAJAS, G. Y. Variables Fisiológicas-Metabólicas de Estrés Calórico en Vacas Bajo Silvopastoreo y Pradera sin Árboles. Rev. Agron. Meso. Amer. 26 (2):211-223. 2015.

[6] BETANCOURT, K.; IBRAHIM, M.; VILLANUEVA, C.; VARGAS, B. Efecto de la cobertura arbórea sobre el comportamiento animal en fincas ganaderas de doble propósito en Matiguás, Matagalpa, Nicaragua. Livest. Res. Rural. Develop. 17 (7): 1-18. 2005.

[7] CHÁVEZ, A.; IERRO, G.; PEÑA, H.R.; SÁNCHEZ, E.; ORTIZ, V. Composición botánica y valor nutricional de la dieta de bovinos en un pastizal mediano abierto en la región central de Chihuahua. Tec. Pec. Mex. 50: 9-105. 1986.

[8] ECHAVARRÍA, A.; MIAZZO, R. El ambiente en la producción animal. 2002. Adaptación, Aclimatación, Estrés, y Clima. Sitio Argentino de producción animal. Facultad de Agronomía y Veterinaria, Universidad Nacional de Río Cuarto. Córdoba, Argentina. En línea: https://bit.ly/3wH03oN.12-05-2021.

[9] ESPINOZA, F.; HERNANDEZ, R. A.; FOLACHE, L. Etología de vaquillas doble propósito en un sistema silvopastoril durante el periodo seco en una Sabana tropical. Instituto Nacional de Investigaciones Agrícolas. Centro Nacional de Investigaciones Agropecuarias. Venezuela. Zoot. Trop. 26 (4):429-437. 2008.

[10] GARCÍA, E. Distribución de los grupos climáticos de Köppen en México. Modificaciones al sistema de clasificación climática de Köppen, 3th. Ed. Universidad Nacional Autónoma de México. Pp 252. 1989.

[11] GENIN, D.; CROCHOT, C.; MSOU, S.; ARABA, A.; ALIFRIQUI, M. Meadow up a tree: Feeding flocks with a native ash tree in the Moroccan mountains. Pastoralism: Res. Pol. Pract. 6 (11): 1-12. 2016.

[12] GÓNGORA, P. R.; GÓNGORA, G. S.; MAGAÑA, M. M.; LARA. L. P. Caracterización técnica y socioeconómica de la producción ovina en el estado de Yucatán, México. Agron. MesoAmer. 21 (1): 131-144. 2010.

[13] HERNÁNDEZ, L.A. Conducta Ingestiva y Comportamiento Animal en Vegetación Multiestrata y Praderas de Gramíneas. Villaflores, Chiapas; Universidad Autónoma de Chiapas. Tesis de Grado. Pp 150. 2003. 
[14] HERNÁNDEZ, H. M.; LÓPEZ, O. S.; JARILLO, R. J.; ORTEGA, J. E.; PÉREZ, E. S.; DÍAZ, R. P.; CROSBY, G. M. Rendimiento y calidad nutritiva del forraje en un sistema silvopastoril intensivo con Leucaena leucocephala y Megathyrsus maximus cv. Tanzania. Rev. Mex. Cien. Pec. 11 (1):53-69. 2020.

[15] HODGSON, J. Longman Handbooks in Agriculture, Essex. Grazing management: science into practice. Pp. 203. 1990.

[16] JOHNSON, H.D. Bioclimatic effects on grout reproduction and milk production of livestock. In: Johnson, H. D. (Ed). Bioclimatology and adaptation of livestock. Amsterdam: Elsevier. Pp. 1-31. 1987.

[17] MAHECHA, L.; DURÁN, C.V.; ROSALES, M.; MOLINA, C. H. Grazing, browsing time and milk production of lucerna cows in a silvopastoral system in different seasons of the year. In: International Symposium on silvopastoral systems 2. Congress on Agroforestry and Livestock Production in Latin America. San José, April 2-9, Costa Rica, Pp 11-18. 2001.

[18] LEMA, M.; FELIX, A.; DORSEY, J. Lamb production and forage quality under a forage system consisting of AU Triumph tall fescue and Tifton 44 Bermuda grass. Small. Rum. Res. 37 (3):249-253. 2000.

[19] LÓPEZ, A.; PINTO, R.; GUEVARA, F.; MEDINA, F.; HERNÁNDEZ, D.; ORTEGA, L. Descripción de la técnica. La microhistología y su aplicación en la agroforestería pecuaria. Editorial Fontamara. $1^{\text {st }}$.Ed. México. 127 pp. 2017.

[20] MARTÍNEZ, G. E.; MUÑOZ, R. M.; GARCÍA, M. J.; SANTOYO, C. V.; ALTAMIRANO, C. J.; ROMERO, M. C. El fomento de la ovinocultura familiar en México mediante subsidios en activos: lecciones aprendidas. Agron. MesoAmer. 22 (2):367-377. 2011.

[21] MOUNT, L.E. Adaptation to thermal environment. Man, and his productive animals. Edward Arnold (Publishers). London. Pp. 13-333. 1979.

[22] NARANJO, J.F.; RIVERA, J.E.; CUARTAS, C.A. Efecto de la oferta y el consumo de Tithonia diversifolia en un sistema silvopastoril intensivo (SSPI), en la calidad y productividad de leche bovina en el piedemonte Amazónico colombiano. Colombia. Livest. Res. Rural. Develop. 27 (10): 1-13. 2015.
[23] ORJUELA-CHAVES, J. A.; CUBILLOS-RODRIGUEZ, J. M.; ORRES-SILVA, O. Evaluación del comportamiento de bovinos de doble propósito bajo diferentes niveles de cobertura arbórea en departamento del Caquetá - Colombia. Universidad de la Amazonia, Florencia - Caquetá. Rev. Fac. Cien. Agrop FAGROPEC.7 (1): 60-64. 2015.

[24] PARRA, H. J.; ESTRADA, C.; GLORIA, E.; PARRA, F. D.; MONTEALEGRE, V. N. Efecto de diferentes sistemas enriquecidos sobre el comportamiento de bovinos doble propósito en producción lechera en la amazonia colombiana. Rev. Electrón. Vet. REDVET. 18 (12): 1-22. 2017.

[25] PATIÑO, P. R.; GONZÁLEZ, M. K.; PORRAS, S. F.; SALAZAR R, L.; VILLALBA, S. C.; BETANCOURT, J. G. Comportamiento ingestivo diurno y desempeño de novillos en pastoreo pertenecientes a tres grupos genéticos durante dos épocas climáticas. Livest. Res. Rural Develop. 20 (36): 15-23. 2008.

[26] PINTO, R. R.; ORTEGA, R. L.; GÓMEZ, C. H.; GUEVARA, H.F.; HERNÁNDEZ, S. D. Comportamiento animal y características de la dieta de bovinos pastoreando estrella africana sola y asociada con árboles. Rev. Mex. Cien. Pec. 5 (3): 365-374. 2014.

[27] QUERO, C. A.; ENRÍQUEZ, Q. J.; MIRANDA, J. L. Evaluación de especies forrajeras en América Tropical, avances o status quo. Caracas. Venezuela. Intercien. 32 (8): 566-571. 2007.

[28] QUERO, C. A.; MIRANDA, J.; VILLANUEVA, A. J. Recursos genéticos de gramíneas para el pastoreo extensivo. Condición actual y urgencia de su conservación ante el cambio climático. Avances en Investigación Agropecuaria - AIA. Rev. Invest. Difus. Cien. Agrop. 21 (3): 63-85. 2017.

[29] SANSORES, L. I. Composición botánica y valor nutricional de la dieta de bovinos en un área de vegetación secundaria en Quintana Roo. Inst. Nac. Invest. Fores. Agrí. Pec. México. Pp 105 - 117. 1999.

[30] STATISTICAL ANALYSIS SYSTEM INSTITUTE (SAS). SAS User Versión 4.0 .1991.

[31] SOLFANELLI, P. Consumo de bovinos en pastoreo. Rev. Soc. Rural de Jesús María, Córdoba. 114: 22-33. 2002. 
[32] SOSA, R.E.; PÉREZ, R. D.; ORTEGA, R. L.; ZAPATA, G. Evaluación del potencial forrajero de árboles y arbustos tropicales para la alimentación de ovinos. Tec. Pec. Mex. 42 (2):129-144. 2004.

[33] SOUZA, D. E.; ABREU, M.; IBRAHIM, M.; HARVEY, C.; JIMÉNEZ, F. Caracterización del componente arbóreo en los sistemas ganaderos de La Fortuna de San Carlos, Costa Rica. Agrofor. Amer. 7 (26): 53-56. 2000.

[34] STOCKDALE, C.; KING, K. Effect of stocking rate on the grazing behaviour and faecal output of lactating dairy cows. Grassland and Forage Sci. 38: 215-218. 1983.

[35] TARAZONA, A.M.; CEBALLOS, M.C.; NARANJO, J.F.; CUARTAS, C.A. Factores que afectan el comportamiento de consumo y selectividad de forrajes en rumiantes. Rev. Colomb. Cien. Pec. 25 (3): 473-487. 2012.

[36] VALLES, B.; CASTILLO, E.; BERNAL, H. Rendimiento y degradabilidad ruminal de materia seca y energía de diez pastos tropicales cosechados a cuatro edades. Rev. Mex. Cien. Pec. 7 (2): 141-158. 2016.

[37] VILLANUEVA, P. C.; DÍAZ, E. V.; CHAY, C. A.; RAMÍREZ, A. L.; CASANOVA, L. F.; OROS, O. I. Comportamiento productivo e ingestivo de ovinos en crecimiento en sistemas silvopastoriles y de engorda en confinamiento. Rev. Mex. Cien. Pec. 10 (4): 870-884. 2019.

[38] WENTZEL, H.; ALONSO, M. Factores que influyen en la utilización de especies leñosas por bovinos y ovinos en sistemas pastoriles. Praderas y forrajes. Facultad de Ciencias Agrarias, Universidad Austral de Chile. Agro. Sur. 48 (1): 1-9. 2020.

[39] ZAMBRANO, C.; ALTUVE, E.; ZAMBRANO, L.; PARRAGA, C. Conducta de ovinos a pastoreo en sistema silvopastoril tradicional con predominio de Saman (Phitecellobium saman) y Guácimo (Guazuma ulmifolia). Rev. Unell. Cien. Tec. (Volumen especial): 29-34. 2010.

[40] ZAMPALIGRÉ, N.; DOSSA, L.H.; SCHLECHT, E. Contribution of browse to ruminant nutrition across three agroecological zones of Burkina Faso. J. Arid Environm. 95: 55-64. 2013.

[41] ZUCCARI, A.E.; FERNÁNDEZ, G.D.; SOLLAZZO, L.A. Evaluación del consumo y comportamiento ingestivo de ovejas bajo dos regimenes de pastoreo durante el mes de enero. Rev. Argen. Prod. Anim. 27 (Supl. 1.): 152-154. 2007. 



\title{
Morfometria y faneroptica de subpoblaciones de cobayos (Cavia porcellus) nativos del altiplano sur ecuatoriano
}

\author{
Morphometric and faneroptic characterization of sub populations native cobayos \\ (Cavia porcellus) of the south equatorian highland
}

\author{
Cornelio Rosales-Jaramillo ${ }^{*}$ (iD, Rafael Róman-Bravo² (iD) y José Aranguren-Méndez² iD \\ ${ }^{1}$ Facultad de Ciencias Agropecuarias, Universidad de Cuenca, Cuenca-Ecuador. ${ }^{2}$ Facultad de Ciencias Veterinarias, \\ Universidad del Zulia. Maracaibo-Venezuela. Correo Electrónico: cornelio.rosales@ucuenca.edu.ec
}

\section{RESUMEN}

El Cuy o Cobayo es un roedor nativo de los Andes sudamericanos de gran importancia para la identidad y seguridad alimentaria de la población, muy cotizado actualmente por las características únicas de su carne. La caracterización morfométrica y faneróptica de las especies animales nativas es el inicio de todo proceso racional de conservación de los recursos zoogenéticos y uso sostenible de las mismas para preservar su variabilidad genética y capacidad de resiliencia. Esta investigación se realizó en el altiplano sur de Ecuador. El objetivo consistió en realizar la caracterización morfométrica y faneróptica de dos subpoblaciones de cobayos (Cavia porcellus) nativos: Cañar (G1EcC), Azuay (G2EcA) y una línea mejorada Perú (G3LP); se registraron datos de 509 animales al nacimiento, 391 al destete y 370 a los 90 días. Para el análisis estadístico se aplicó estadística descriptiva, análisis de varianza con test de Duncan al $5 \%$ para datos con normalidad y Kruskal-Wallis y Mann-Whitney para datos sin normalidad. Las subpoblaciones nativas son animales corporalmente más pequeños comparados con los animales mejorados, con presencia de polidactilia, ojos de color negro, con una capa de tipo lacio corto y colores overo - agouti predominantes.

Palabras clave: Cobayo; zoogenéticos; fenotipo; características fanerópticas

\section{ABSTRACT}

The guinea pig is a native rodent of the South American Andes of great importance for the identity and food security of the population, very much quoted at present for the unique characteristics of its meat. The morphometric and phaneroptic characterization of native animal species is the beginning of any rational process of conservation of animal genetic resources and their sustainable use to preserve their genetic variability and resilience. This research was carried out in the Southern Highlands of Ecuador. The objective was to perform the morphometric and phaneroptic characterization of two subpopulations of native guinea pigs (Cavia Porcellus): Cañar (G1EcC), Azuay (G2EcA) and an improved line Peru (G3LP); data were recorded on 509 animals at birth, 391 at weaning and 370 at 90 days. For the statistical analysis, descriptive statistics were applied, analysis of variance with the Duncan test at $5 \%$ for normal data and Kruskal-Wallis and MannWhitney for data without normality. The native subpopulations were smaller animals as compared to the improved animals, with the presence of polydactyly, black eyes, with a short straight type coat and predominant overo - agouti colors.

Key words: Guinea pig; zoogenetics; phenotypes; phaneroptic characteristics 


\section{INTRODUCCION}

El Cobayo (Cavia porcellus) roedor histricomorfo de la familia Caviidae, es un mamífero originario de la zona andina sudamericana, especialmente de Bolivia, Colombia, Ecuador y Perú. Se le conoce también con los nombres de cuy, conejillo de Indias, cobayo, acure; es apreciado como alimento de alto valor nutricional que contribuye a la seguridad alimentaria de las familias rurales y urbanas aportando importantes nutrientes, lo que ha influido para que haya ganado mercado y aceptación global $[4,6]$.

El origen del Cobayo yace desde la antigüedad, citándose restos arqueológicos de cobayos silvestres, encontrados en Colombia, Perú y Chile y que datan entre los 9.000 a 8.000 años antes de Cristo (AC), siendo de estos hallazgos los más antiguos, los encontrados en la Sabana Bogotana de Tequendama en Colombia. Según algunos investigadores, el Cobayo constituye el roedor que más tempranamente fue domesticado, entre los 6.000 a 2.000 AC $[8,17,18]$.

En América del Sur, la domesticación de animales se concentra básicamente en cuatro especies, siendo una de ellas el Cobayo, evidencia ésta, dada por la abundancia de restos encontrados de esta especie, presumiendo su domesticación en esta región alrededor de los $2.500 \mathrm{AC}$, aunque existen evidencias, que se haya consumido su carne mucho antes, a través de la cacería de animales silvestres [17].

Estudios recientes basados en secuencias de mitogenoma proponen la existencia de dos núcleos principales de domesticación, muy probablemente originados con especies diferentes: el primero ubicado en Colombia basado en el Cavia anolaimae, de no muy lejano reconocimiento y otro núcleo, éste de origen andino central concentrado en el sur de Perú y norte de Chile, basado en el Cavia tschudii [18]; sin embargo, con el descubrimiento en la región central de Ecuador de la especie Cavia patzelti, no sería extraño que haya existido un tercer núcleo o proceso de domesticación [9].

Su clasificación taxonómica corresponde a:

Reino: Animalia

Subreino: Bilateria

Infrareino: Deuterostomia

Tipo: Chordata

Subtipo: Vertebrata

Infratipo: Gnathostomata

Superclase: Tetrapoda

Clase: Mammalia

Subclase: Theria

Infraclase: Eutheria

Orden: Rodentia

Suborden: Hystricomorpha

Infraorden: Hystricognathi

Familia: Caviidae

Subfamilia: Caviinae

Género: Cavia

Especie: Cavia porcellus

[15]
La población total real de Cobayos en Sudamérica, según censos agropecuarios entre 2013 y 2017 superan a los 100 millones (mill) de animales en Latinoamérica, distribuidos en Perú 65 mill [14], Ecuador 47 mill [13], Bolivia 3 mill [1] y Colombia 2,3 mill [10]; no obstante, la población en la actualidad se estiman serian de en Perú 17,38 mill, Ecuador 21,0 mill, Bolivia 0,647 mill y Colombia 1,234 mill de animales, de acuerdo a estimaciones de asociaciones no oficiales [20].

Los países ven reflejada su identidad cultural y tradiciones en la flora y fauna, por ello la variabilidad de los organismos en los ecosistemas, intraespecie o entre ellas, es un elemento importante para el desarrollo de la seguridad alimentaria y sostenibilidad de los pueblos. El menoscabo de esta variabilidad, acarrea la pérdida de dicha identidad, así como una parte del patrimonio de la humanidad y pone en riesgo la seguridad y autonomía alimentaria lo que obliga a propiciar el uso sostenible y la conservación de los recursos zoogenéticos para la agricultura y alimentación [21]. Un claro ejemplo lo constituye la crianza de los Cobayos por el hombre andino, destinándolo principalmente como medio de fuente de proteína, es decir para el consumo de su carne e incluso en algunas zonas su piel, es utilizada para hacer ropa, tal como se da en la sierra ecuatoriana $[2,6]$.

La conservación de los recursos zoogenéticos locales es una estrategia para garantizar la diversidad de los recursos buscando su uso sostenible para equilibrar las necesidades actuales y los objetivos de las generaciones futuras [7], además de propender a la preservación de los materiales biogenéticos de los animales domésticos que asegure su perpetuidad a lo largo del tiempo sin perder este valioso material [19].

A nivel mundial, los problemas reconocidos que enfrentan los recursos genéticos de animales criollos son los siguientes:

a) La disminución de la variabilidad genética dentro de razas o líneas de alta producción empleadas en sistemas intensivos de producción. b) La rápida desaparición de razas locales debido a la introducción de razas exóticas.

Frente a la problemática planteada, la Organización de las Naciones Unidas para la Alimentación y la Agricultura (FAO) [12] plantea desarrollar programas de acción para el manejo sostenible de la genética animal, su preservación (in situ y ex situ) y la formación de bancos de datos de recursos genéticos locales [11], considerando un protocolo lógico de acciones que permitan la conservación de poblaciones en peligro de extinción. Esta propuesta considera cinco fases iniciándose por la descripción general de la población en estudio, en donde se incluye precisamente la descripción de las características raciales, productivas, reproductivas, ecológicas, entre otras.

Para tal propósito se recomienda iniciar con la caracterización animal, siendo ésta la determinación de los atributos estructurales o funcionales de un individuo o grupo de individuos que particulariza a las líneas/razas o especies [12, 24]. Para ello, la morfología se determina de dos formas: atendiendo a los caracteres morfológicos o fanerópticos que son de naturaleza cualitativa (capa, color de ojos, de orejas, entre otras.) o atendiendo a los de estructura, que son cuantitativos y por lo tanto, factibles de medir a través de mediciones corporales concretas que cuantifican la conformación corporal [7, 24], información fundamental para procesos de selección y mejoramiento sostenibles en el propósito de formar 
líneas genéticas mejoradas, partiendo de germoplasma nativo buscando mantener la aptitud de resiliencia pero satisfaciendo las necesidades tanto económicas como alimenticias de productores y consumidores [4-6, 23].

En base a este lineamiento de la FAO, se planteó el objetivo principal de esta investigación, que consistió en describir las características morfométricas y fanerópticas de dos poblaciones de Cobayos ecuatorianos nativos (Cañar y Azuay) pertenecientes a subpoblaciones nacionales, para acercarse al conocimiento de su morfología y comportamiento en general y a su vez compararlos con una línea comercial mejorada (Perú).

\section{MATERIALES Y METODOS}

El estudio se llevó a cabo en la granja experimental de Irquis, de la Facultad de Ciencias Agropecuarias de la Universidad de Cuenca, ubicada en el altiplano sur del Ecuador, cuyas coordenadas son: $4^{\circ} 48^{\prime} 34^{\prime \prime}$ LS y $79^{\circ} 4^{\prime} 30.12^{\prime \prime}$ LO; a una altitud de 2.664 metros sobre el nivel del mar (m.s.n.m.), humedad relativa del $80 \%$, pluviosidad entre 800 - 2000 milímetros (mm) y temperatura que oscila entre 7 y $12^{\circ} \mathrm{C}$.

Los datos se registraron en diferentes etapas de la vida de los animales. Se usaron al nacimiento, 211 descendientes de la subpoblación Cañar (G1EcC) (FIG.1A), 143 descendientes de la subpoblación Azuay (G2EcA) (FIG.1B) y 155 descendientes de línea Perú (G3LP); al destete 166 (G1EcC), 113 (G2EcA) y 112 (G3LP); y a los 90 días (d) 157 (G1EcC), 108 (G2EcA) y 105(G3LP), todos ellos mantenidos bajo un mismo sistema de crianza, de manejo y alimentación. Las medidas fueron tomadas en base a la metodología establecida por Tirira [26] y con el uso de un calibrador digital Vernier SHARS Aventor® 8»/200mm, EUA) y una balanza de precisión BPS 52 plus $B O E C O \circledast$, Alemania) con precisión de 0,01 gramo $(\mathrm{g})$.

Las variables morfométricas y fanerópticas determinadas fueron: largo total del cuerpo (LT), medida que va desde el extremo del hocico hasta el extremo de la cola; largo de la cabeza (LC) desde el extremo del hocico hasta la nuca; largo de la pata posterior (LP), desde el talón hasta la punta de la garra; largo de la oreja (LO), desde su base hasta la punta, por la cara anterior; alzada de cabeza $(A C)$; peso individual $(P)$; número de dedos en los miembros anteriores (NDA); número de dedos en los miembros posteriores (NDP); tipo de pelaje (TP) si eran lisas, enrosetadas o ensortijadas (FIG. 2); color de ojos (CO); color de orejas (COr); color de capa (CC) las cuales se clasificaron en: simple que implica un solo color entero y firme, el overo dos colores firmes claramente definidos y el compuesto o agouti formado por combinaciones indefinidas de pelos de diferente color (FIGS. 3 y 4 ).

El análisis estadístico se realizó aplicando estadística descriptiva, tablas de frecuencia, histogramas, además prueba de ShapiroWilk para normalidad, ANAVA a una vía de clasificación, para comparar las poblaciones se utilizaron prueba de Duncan $(P<0,05)$ y para aquellas variables cuyos residuos no se ajustaron a una distribución normal se usaron las pruebas de KruskalWallis y Mann-Whitney, todo ello utilizando el paquete estadístico SAS 9.0 [25].

\section{RESULTADOS Y DISCUSION}

De acuerdo a los datos encontrados (TABLA I) se observó que las subpoblaciones Azuay (G2EcA) y Cañar (G1EcC) responden a una morfología externa diferente en todos los parámetros estudiados, a excepción del largo de oreja en donde no muestran diferencias estadísticas $(P>0,05)$. Se encontraron diferencias significativas con valores a favor de la subpoblación Cañar, mostrándose como un animal de mayor tamaño y peso en todas las etapas de la vida estudiadas pasando de un largo de cuerpo de 12,42 centímetros $(\mathrm{cm}) \pm 0,09$ y un peso de $113,52 \mathrm{~g} \pm 2,51$ al nacimiento a 23,63 cm $\pm 0,18$ y $667,88 \mathrm{~g} \pm 10,45$ a los $90 \mathrm{~d}$ de edad frente a $11.91 \mathrm{~cm} \pm 0,08$ y un peso de $102,62 \mathrm{~g} \pm 2,23$ al nacimiento, a 21,12 cm $\pm 0,23$ y 512,6 g $\pm 13,41$ a los $90 \mathrm{~d}$ de edad en la variedad Azuay.
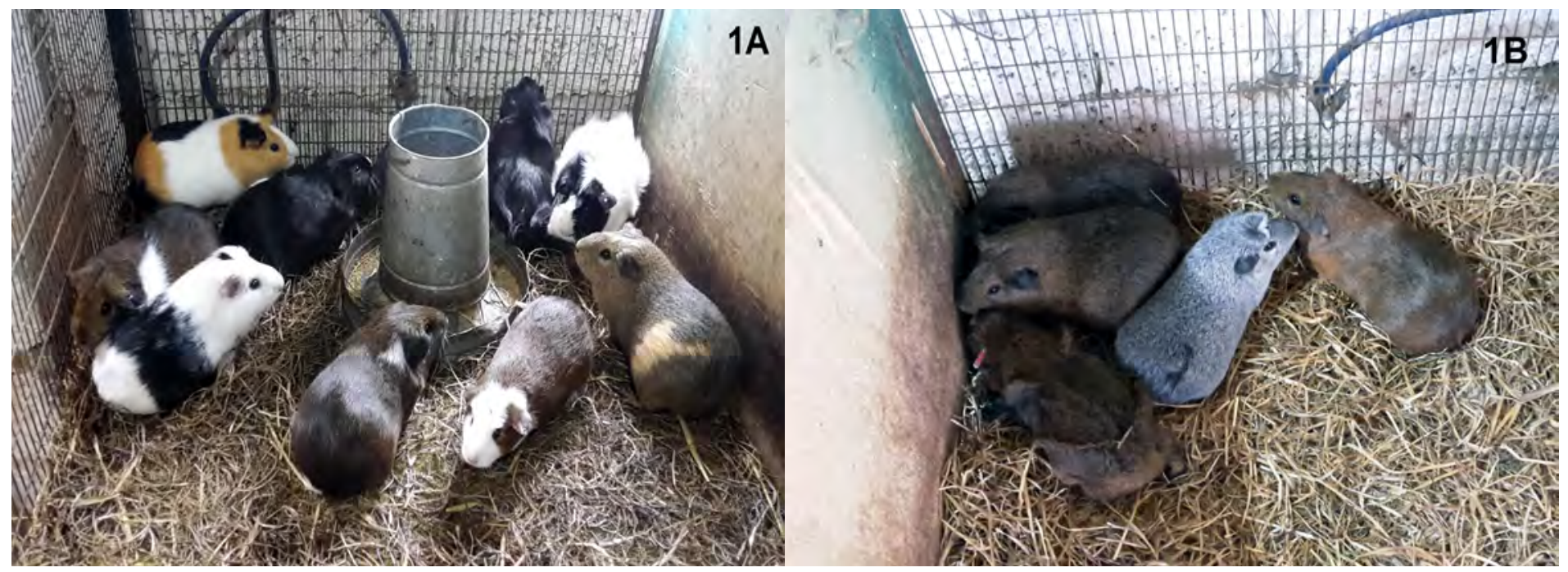

FIGURA 1. Subpoblación Cañar (1A) y subpoblación Azuay (1B) de cobayos nativos del altiplano sur del Ecuador 
Morfometria y faneroptica de cobayos nativos / Rosales-Jaramillo y col.

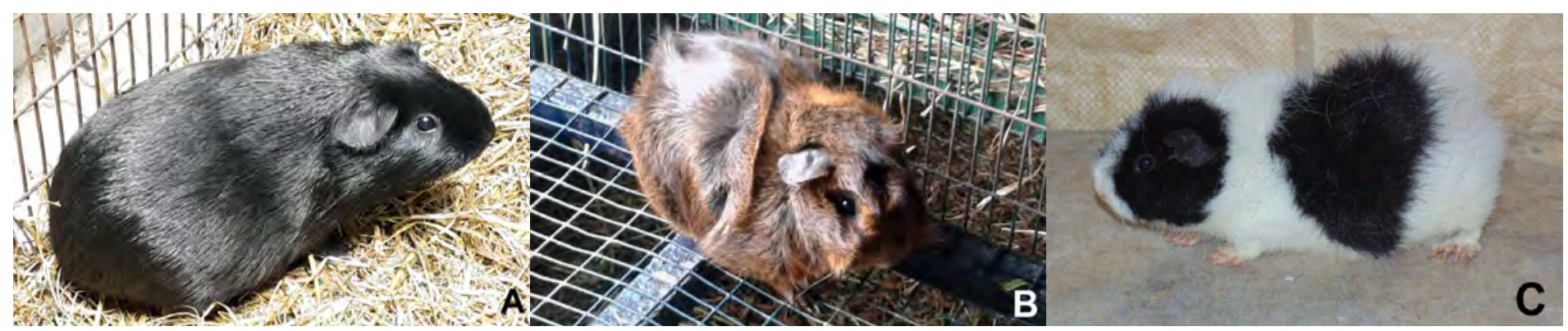

FIGURA 2. Ejemplar de cobayo nativo del altiplano sur del Ecuador, con pelo liso (A), pelo enrosetado (B) y ensortijado (C)
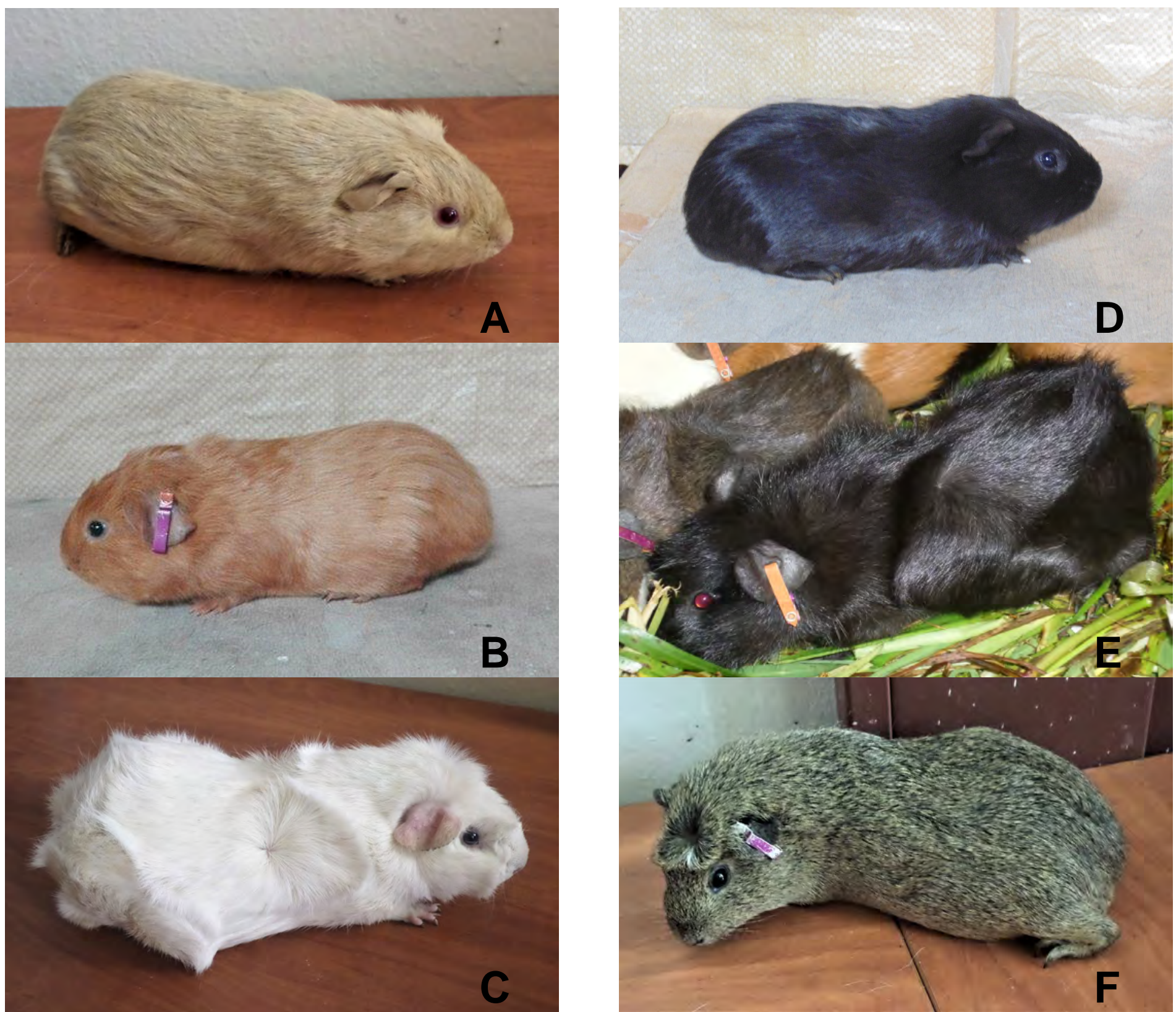

FIGURA 3. Principales colores de capa solida: Bayo (A), Alazán (B), Blanco (C), Violeta (D), Negro (E) y Agoutí crema (F), presentados en subpoblaciones de cobayos nativos del altiplano sur del Ecuador 

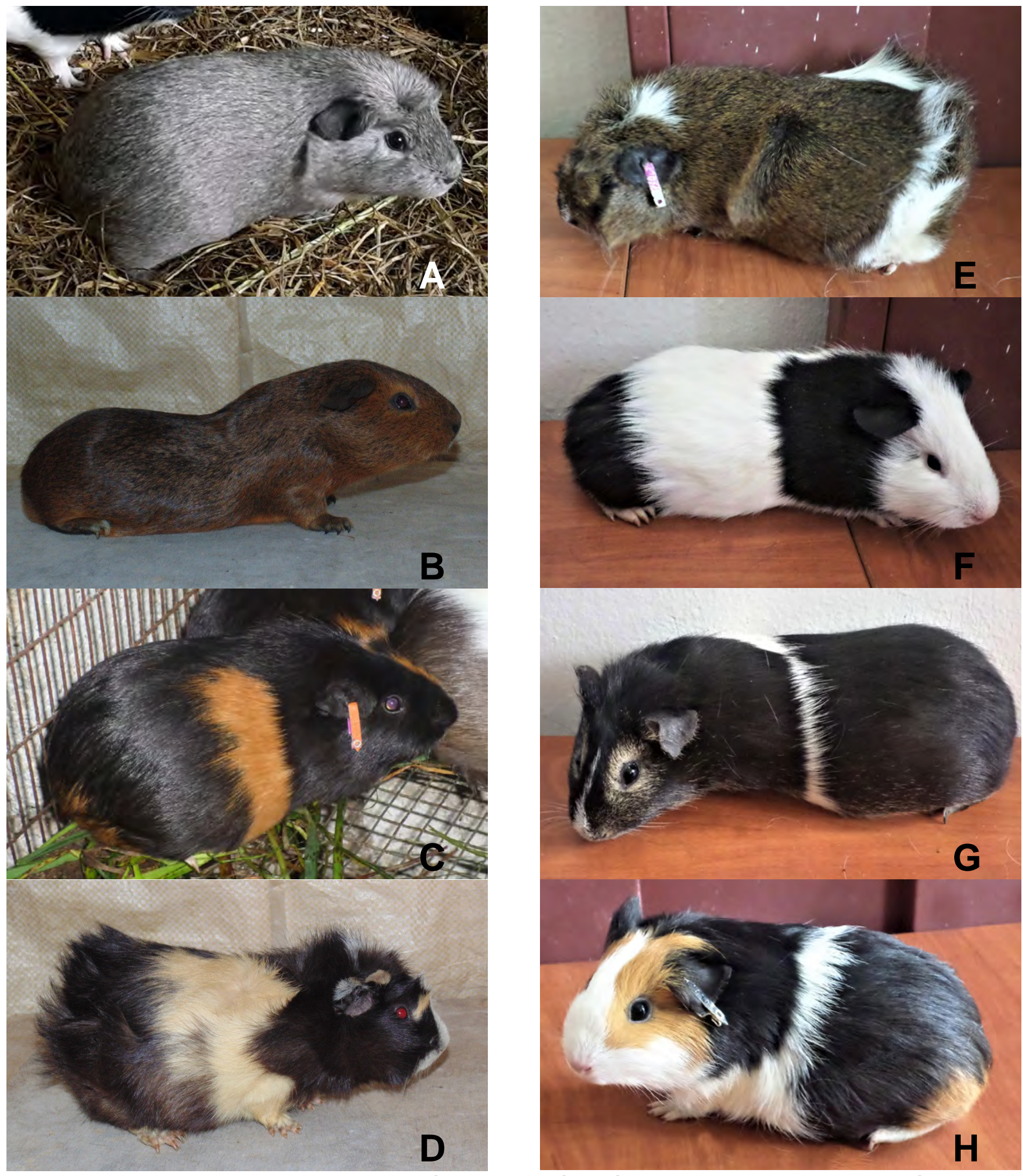

FIGURA 4. Principales colores de capa solida: Agoutí gris (A), Agoutí marrón (B) y capa combinada: Negro alazán (C), Negro bayo (D), Agoutí overo (E), Overo negro (F), Negro overo (G) y Combinado (H), presentados en subpoblaciones de cobayos nativos del altiplano sur del Ecuador 
Morfometria y faneroptica de cobayos nativos / Rosales-Jaramillo y col.

TABLA I

Indicadores morfométricos y fanerópticos de cobayos nativos Azuay, Cañar y línea Perú

\begin{tabular}{|c|c|c|c|c|}
\hline Variable & Procedencia & $\begin{array}{c}\text { Al nacimiento } \\
\overline{\mathrm{X}} \pm \mathrm{EE}\end{array}$ & $\begin{array}{c}\text { Al destete } \\
\bar{X} \pm E E\end{array}$ & $\begin{array}{c}\text { A los } 90 \text { días } \\
\bar{X} \pm E E\end{array}$ \\
\hline \multirow{3}{*}{$\begin{array}{l}\text { Largo total } \\
\text { cm. }\end{array}$} & G1EcC & $12,42 \pm 0,09^{b}$ & $16,11 \pm 0,18^{b}$ & $23,63 \pm 0,18^{b}$ \\
\hline & G2EcA & $11,91 \pm 0,08^{c}$ & $15,13 \pm 0,17 c$ & $21,12 \pm 0,23 c$ \\
\hline & G3LP & $13,49 \pm 0,15^{a}$ & $17,14 \pm 0,29 a$ & $26,42 \pm 0,22^{a}$ \\
\hline \multirow{3}{*}{$\begin{array}{l}\text { Largo de cabeza } \\
\text { cm. }\end{array}$} & G1EcC & $4,79 \pm 0,03 b$ & $5,28 \pm 0,04^{b}$ & $6,77 \pm 0,03^{b}$ \\
\hline & G2EcA & $4,56 \pm 0,03^{c}$ & $5,18 \pm 0,04^{b}$ & $6,39 \pm 0,04^{c}$ \\
\hline & G3LP & $5,20 \pm 0,05^{a}$ & $5,82 \pm 0,07 a$ & $7,36 \pm 0,04^{a}$ \\
\hline \multirow{3}{*}{$\begin{array}{l}\text { Alzada de cabeza } \\
\text { cm. }\end{array}$} & G1EcC & $4,53 \pm 0,04^{b}$ & $5,01 \pm 0,04^{b}$ & $6,46 \pm 0,04^{b}$ \\
\hline & G2EcA & $4,31 \pm 0,03^{c}$ & $4,82 \pm 0,04^{c}$ & $6,02 \pm 0,05^{c}$ \\
\hline & G3LP & $4,84 \pm 0,06^{a}$ & $5,49 \pm 0,06^{a}$ & $6,93 \pm 0,05^{a}$ \\
\hline \multirow{3}{*}{$\begin{array}{l}\text { Largo de oreja } \\
\text { cm. }\end{array}$} & G1EcC & $2,27 \pm 0,03^{b}$ & $2,51 \pm 0,04^{b}$ & $3,13 \pm 0,11 a b$ \\
\hline & G2EcA & $2,21 \pm 0,03^{b}$ & $2,50 \pm 0,04^{b}$ & $2,91 \pm 0,14^{b}$ \\
\hline & G3LP & $2,57 \pm 0,05^{a}$ & $2,73 \pm 0,07^{a}$ & $3,34 \pm 0,14^{a}$ \\
\hline \multirow{3}{*}{$\begin{array}{l}\text { Largo de pata } \\
\text { cm. }\end{array}$} & G1EcC & $3,63 \pm 0,03 b$ & $3,83 \pm 0,02 \mathrm{~b}$ & $4,53 \pm 0,02 b$ \\
\hline & G2EcA & $3,47 \pm 0,02^{c}$ & $3,70 \pm 0,02^{c}$ & $4,26 \pm 0,03 c$ \\
\hline & G3LP & $4,18 \pm 0,04^{a}$ & $4,27 \pm 0,04^{a}$ & $5,13 \pm 0,03 a$ \\
\hline \multirow{3}{*}{$\begin{array}{l}\text { Peso } \\
\text { g. }\end{array}$} & G1EcC & $113,52 \pm 2,51 b$ & $224,15 \pm 5,48 b$ & $667,88 \pm 10,45 b$ \\
\hline & G2EcA & $102,62 \pm 2,23^{c}$ & $203,08 \pm 5,32^{c}$ & $512,66 \pm 13,41 c$ \\
\hline & G3LP & $150,26 \pm 4,08^{a}$ & $289,28 \pm 8,71^{a}$ & $1011,16 \pm 12,92^{a}$ \\
\hline \multirow{3}{*}{$\begin{array}{c}\text { Número de dedos } \\
\text { anteriores }\end{array}$} & G1EcC & $4,34 \pm 0,07^{c}$ & - & - \\
\hline & G2EcA & $4,17 \pm 0,06^{b}$ & - & - \\
\hline & G3LP & $3,98 \pm 0,11 \mathrm{a}$ & - & - \\
\hline \multirow{3}{*}{$\begin{array}{l}\text { Número de dedos } \\
\text { posteriores }\end{array}$} & G1EcC & $3,69 \pm 0,08^{b}$ & - & - \\
\hline & G2EcA & $3,53 \pm 0,08^{b}$ & - & - \\
\hline & G3LP & $3,05 \pm 0,02 \mathrm{a}$ & - & - \\
\hline
\end{tabular}

Letras diferentes en columna indican diferencia significativa $(P<0,05)$

Estos valores encontrados comparados con los descritos por Kunz [16], para Cobayos amerindios resultan ser inferiores, por el contrario, otro estudio en variables similares en Cobayos negros encontró valores inferiores a los descritos en la presente investigación [2]. No obstante, al comparar estas subpoblaciones locales (Cañar y Azuay) con animales de línea mejorada (Perú) se encuentra que son animales inferiores en toda su morfología a excepción del largo de oreja, con seguridad está determinado por los procesos de selección a los cuales ha sido sometida la especie, observándose que desde el nacimiento son animales de mayor tamaño y peso con valores de 1,07 y 1,58 cm y 36,74 y 47,64 g. más que Cañar y Azuay, respectivamente; dichas diferencias se hacen más marcadas a los $90 \mathrm{~d}$ en donde los animales ya han expresado todo su potencial productivo siendo 2,79 y $5,3 \mathrm{~cm}$ y 343,28 y 498,5 g más que Cañar y Azuay, respectivamente.

La polidactilia, factor considerado como causal de descarte en las líneas mejoradas [3, 27], aún se encuentra presente con relativa alta frecuencia en los animales nativos, tanto en extremidades anteriores como posteriores, en virtud de que en estos últimos, es muy poco el mejoramiento genético realizado y poco el control de los apareamientos, siendo muy común aquellos de orden consanguíneos $[19,20]$. El 23,2 \% de animales de origen Cañar presentaron polidactilia en los miembros anteriores frente a un $12,6 \%$ en Azuay y un 0,6 \% en la línea Perú; por el contrario, Azuay presentó un mayor porcentaje 33,6 \% en los miembros posteriores frente a un 29,9 y 4,5\% en Cañar y mejorado, respectivamente, estos valores difieren de los mencionados por 
otro autor [22], observándose que los nativos bolivianos presentan mayor frecuencia de polidactilia $30 \%$ en los miembros anteriores que los nativos ecuatorianos, por el contrario presentan menor frecuencia $(26,6 \%)$ en los miembros posteriores, de igual forma otros investigadores encontraron un porcentaje promedio mayor (45 \%) de polidactilia en cobayos del cantón Loja [3]

En cuanto al número de dedos, los animales nativos muestran un mayor promedio, la subpoblación Cañar $(3,69 \pm 0,08)$ sobresale con un 16,6 y $14,7 \%$ de animales con 6 dedos en extremidades anteriores y/o posteriores, respectivamente; en Azuay $(3,53 \pm 0,08)$ sobresale un $8,4 \%$ para miembros anteriores con 6 dedos y un $21,2 \%$ con 4 dedos en miembros posteriores, encontrándose un máximo de 7 dedos anteriores y posteriores en un porcentaje menor al 1 \% únicamente en cobayos nativos. Los hallazgos son similares a los mencionados por Rico [23], en Cobayos nativos bolivianos, especialmente en los miembros anteriores Cobayo promedio es 4,33 ya que en los posteriores presentan un menor promedio de 3,28 al encontrado en los nativos ecuatorianos.

En cuanto al tipo de pelo (FIG. 5), el corto y lacio es el predominante en las subpoblaciones estudiadas, encontrándose el 83,4 y $76,2 \%$ en los animales de procedencia Cañar y Azuay, respectivamente; mientras que, los porcentajes restantes corresponden a animales con pelo corto y arrosetado, estos tipos de pelo se corresponden con los encontrados en otras investigaciones [23]; la línea Perú solo presenta pelo corto y liso.

Las subpoblaciones nativas Cañar y Azuay se caracterizan por presentar una capa de color overo y agoutí encontrándose este último exclusivamente en los Cobayos nativos (FIG. 6). En Cañar, el $8,1 \%$ de animales presentaron una capa de color simple con presencia de negro, blanco y alazán, el $47,4 \%$ fueron overos con presencia de blanco en combinación con el agoutí, negro, alazán y viceversa, por último, un 44,5 \% presentó una capa compuesta

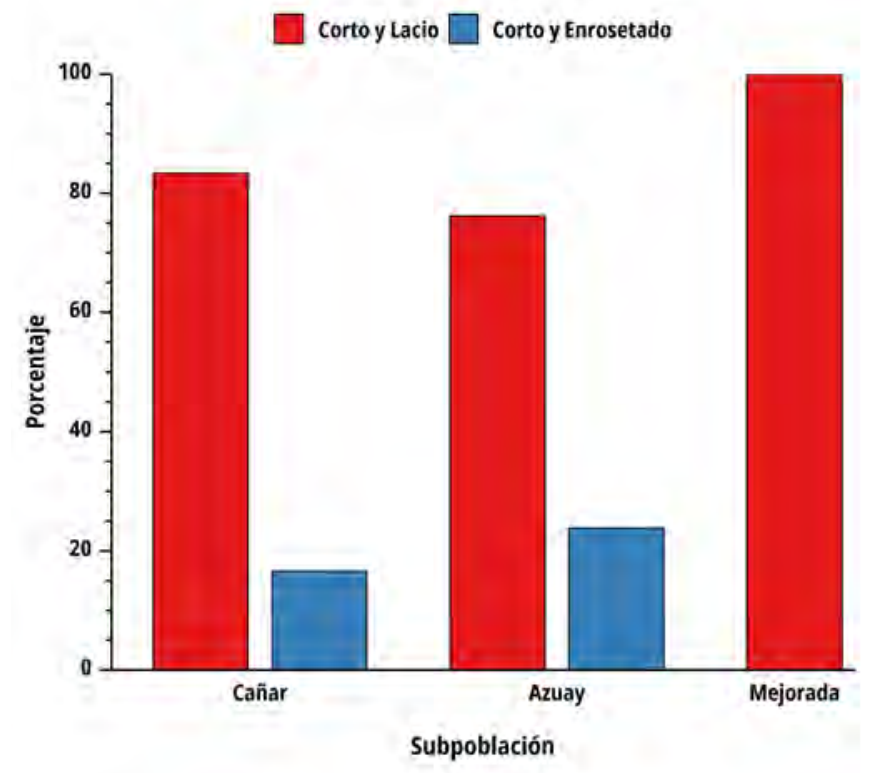

FIGURA 5. Composicion de subpoblaciones de acuerdo al tipo de pelo

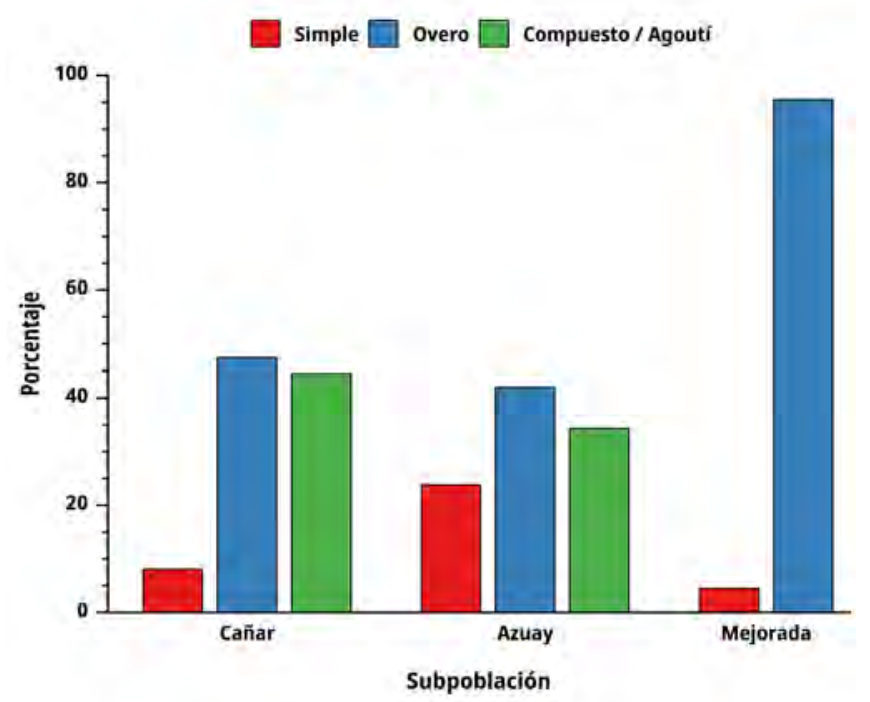

FIGURA 6. Composicion de subpoblaciones de acuerdo al color de la capa

o agoutí siendo ruano, lobo, moro y más de 3 colores definidos blanco, bayo, alazán, negro, plomo, agoutí. En Azuay, el 23,8 \% de animales presentaron una capa simple, el mayor porcentaje $42 \%$ fueron overos en ambos grupos con colores iguales a Cañar y para el color de capa compuesta el porcentaje fue de $34,3 \%$ con combinaciones de colores marrón, lobo, ruano, moro, todos los colores hallados son coincidentes con los descritos anteriormente [23]; la línea Perú debido a los procesos de selección el color overo es el predominante en donde el más representativo fue el alazán con blanco y el restante fue para colores simples como el blanco, bayo y alazán.

En cuanto al color de ojos, en las tres subpoblaciones prevalece el color negro existiendo apenas un $2 \%$ de color rojo, valor similar al mencionado previamente [22]. El color de oreja negra es el más común en las tres subpoblaciones, tanto en la oreja izquierda como en la derecha, seguido del moteado y el menor porcentaje de animales presenta oreja rosada (FIG. 7); no siempre existe coincidencia de color de oreja izquierda y derecha en los animales.

\section{CONCLUSIONES}

A partir de la información analizada, se puede indicar que las subpoblaciones nativas estudiadas presentan características diferentes entre sí, son de menor peso y tamaño corporal en comparación con la línea mejorada Perú, con presencia de polidactilia en las patas delanteras y traseras debido a los procesos de selección poco rigurosa y posible consanguinidad presentes en los sistemas tradicionales de crianza en ellos prevalece el pelo lacio y corto, con color de capa diversa con alta presencia de overos y agoutí color típico de los animales silvestres, acompañado con ojos y orejas de color negro; todas las características presentes hacen prever todavía la existencia de una considerable variabilidad genética. 


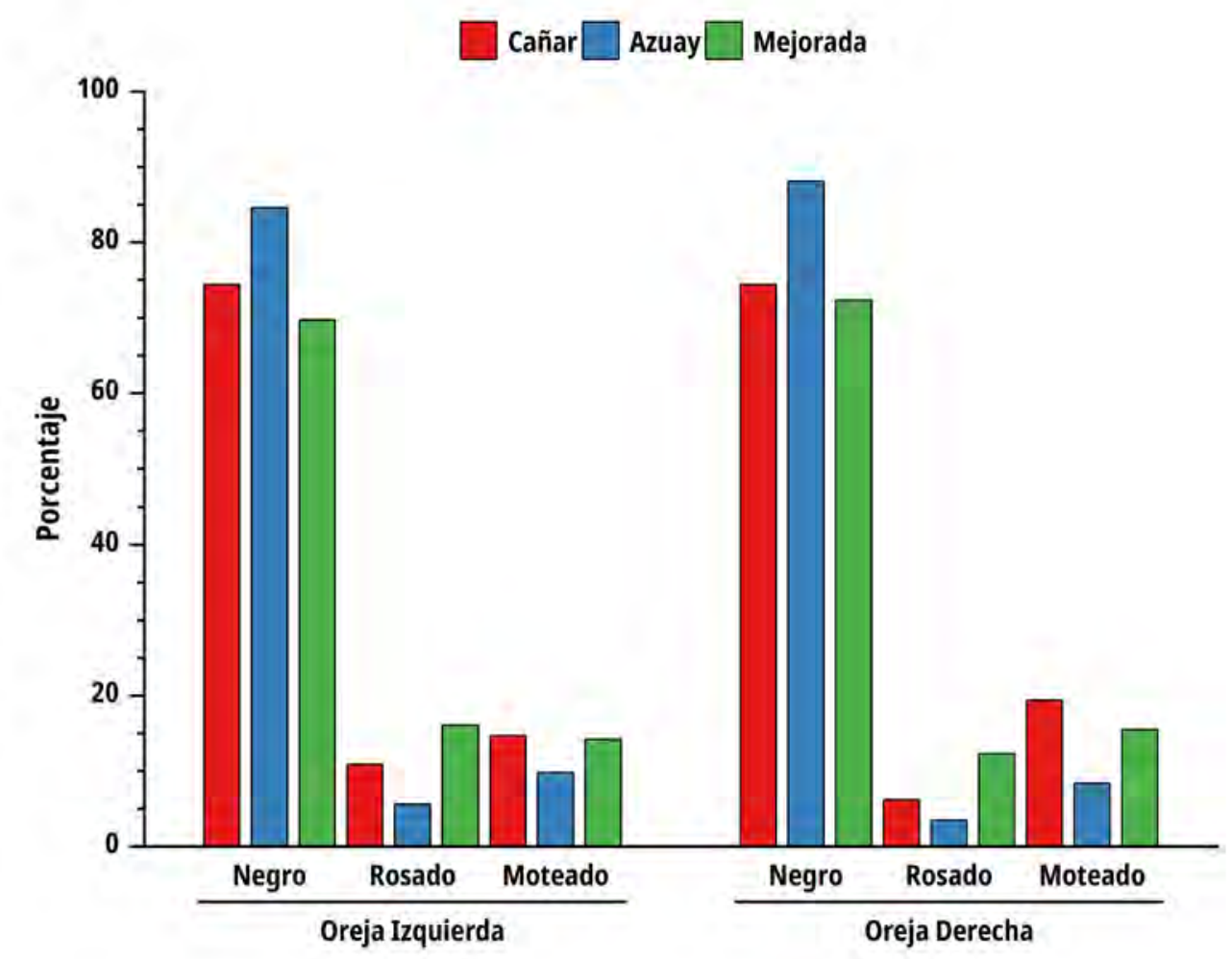

FIGURA 7. Composicion de subpoblaciones de acuerdo al color de las orejas

\section{AGRADECIMIENTO}

Especial mención a la Dirección de Investigación de la Universidad de Cuenca (DIUC), Cuenca-Ecuador, por el financiamiento de esta investigación.

\section{REFERENCIAS BIBLIOGRAFICAS}

[1] ARCHIVOS NACIONAL DE DATOS (ANDA). Censo Agropecuario del Estado Plurinacional de Bolivia, 2013. La Paz, Bolivia. En Línea: https://bit.ly/3gTtA82. 18/08/2020.

[2] BARRERA, A.; USCA, J.; DIAZ, H.; CASTILLO, B. Evaluación de las Características Productivas y Reproductivas de Cobayos Negros manejados en jaulas versus pozas. Rev. Carib. Cien. Social. 12 (3):103-107. 2018.

[3] BENITEZ, E.; ULLAGUARI, V.; GUZMAN, J.; ABAD, R. Estado de la polidactilia en poblaciones de cobayos (Cavia porcellus) en el cantón Loja, como indicador de su estatus genético. Centro Biotecnol. 6:36-40. 2017.

[4] CHAUCA, L. Producción de Cobayos (Cavia porcellus). En: Estudio FAO Produccion y Sanidad Animal No. 138 (Ed.) Roma - Italia. 134 pp. 1997.

[5] CHAUCA, L. Logros obtenidos en la mejora genética del Cobayo (Cavia porcellus). Experiencias del INIA. Arch. Latinoam. Prod. Anim. 15:218 - 222. 2007

[6] CHAUCA, L. Crianza del Cobayo Cavia porcellus y su impacto en el desarrollo rural. Proc. XXXVIII Reunion de la
Asociacion Peruana de Produccion Anim. (APPA). Lima, 12/04-06, Peru. Pp: 64-69. 2013.

[7] CONSORCIO GTZ/FUNDECO/IE. Estrategia regional de biodiversidad. Protección, recuperación y difusión de conocimientos y prácticas tradicionales. (Eds.). BID \& Comunidad Andina de Naciones, Lima. 97 pp. 2001.

[8] DIGARD, J. Un Aspect méconnu de l'histoire de l'Amérique : la domestication des animaux. L'Homme. 32:253-270. 1992.

[9] DUNNUNM, J.; SALAZAR, J. Molecular systematics, taxonomy and biogeography of the genus Cavia (Rodentia: Caviidae). $\mathbf{J}$. Zool. System. Evolut. Res. 48 (4): 376-388. 2010.

[10] ENCUESTA NACIONAL AGROPECUARIA (ENA). Oferta Agropecuaria, ENA - Cifras 2013. Bogotá, Colombia. En Línea: http://www.agronet. gov.co. 05/10/2020.

[11] FOOD AND AGRICULTURE ORGANIZATION (FAO). Lista Mundial de Vigilancia para la Diversidad de los Animales Domésticos. SCHERF, B. (Ed.) 2nd. Ed. FAO, Roma. 777 pp. 1997.

[12] FOOD AND AGRICULTURE ORGANIZATION (FAO). La situación de los recursos zoogenéticos mundiales para la alimentación y la Agricultura. PILLING, B.R. (Ed.) FAO, Roma. 555 pp. 2010.

[13] INSTITUTO NACIONAL DE ESTADISTICAS Y CENSO (INEC). III Censo Agropecuario. Ecuador. En Línea: http://www. inec.gov.ec. 18/10/2020. 
[14] INSTITUTO NACIONAL DE ESTADISTICA E INFORMATICA (INEI). Censo Agropecuario-CENAGRO 2017. Lima, Perú. En Línea: http://www.inei.gob.pe. 18/10/2020.

[15] INTEGRATED TAXONOMIC INFORMATION SYSTEM. ITIS Report. Base de datos Electronica de los Recursos On Line Animales. https://www.itis.gov/ 18-05-2020.

[16] KUNZ, M. Estudio Comparado de Variables Corporales y Tamaño de Camada en Cobayos (Cavia porcellus) Amerindios (Arica) y de Laboratorio desde el Nacimiento hasta los cuatro meses de edad. Facultad de Ciencias Veterinarias y Pecuarias - Universidad de Chile. Tesis de Grado. 345 pp. 2003.

[17] LAVALEÉ, D. La Domestication Animales En Amerique Du Sud - Le point des connaissances. Bull. Inst. Fr. Études Andines. 19 (1):25-44. 1990.

[18] LORD, E.; COLLINS, C.; DE FRANCE, S.; LEFEBVRE, M.; PIGIÉRE, F.; EECKHOUT, P.; ERAUW, C.; FITZPATRICK, S.M.; HEALY, P.; MARTINEZ-POLANCO, M.; GARCIA, J.L.; RAMOS, E.; DELGADO, M.; SANCHEZ, A.; PEÑA, G.; TOYNE, J.; DAHLSTED, A.; MOORE, K.; LAGUER, C.; ZORI, C.; MATISOOSMITH, E. Ancient DNA of Guinea Pigs (Cavia spp.) Indicates a Probable New Center of Domestication and Pathways of Global Distribution. Scientif. Rep. 10:8901-8908. 2020.

[19] MANTILLA, J. Mejoramiento Genético y Conservación de Cobayos Nativos en el Perú. Sistema de Revisiones en Investigación Veterinaria de San Marcos. Cajamarca, 08/1214, Peru. Pp 1-5. 2009.
[20] PATIÑO, R.; CARDONA, J.; CARLOSAMA, L.; PORTILLA, P.; MORENO, D. Zootechnical parameters of Cavia porcellus in production systems in Nariño and Putumayo (Colombia). Rev. CES Med. Zoot. 14 (3):29-41. 2019.

[21] RAYMONDI, J. Evaluación Genética de un Plantel de Cobayos Reproductores de Genotipo Perú. Rev. Inv. Vet. Perú. 28 (2): 293-298. 2017.

[22] RICO, E. Planteles de Cobayos locales e introducidos en Bolivia. Proc. Seminario Internacional: Avances en Investigación, Organización Empresarial, Producción, Procesamiento y Comercialización de Cobayos. Lima, 08/22-23, Peru. 11pp. 2010.

[23] RICO, E.; RIVAS, C. Conservación de poblaciones nativas de Cobayos. Rev. Invest. Agrop. Fores. Boliv. 1(2):49-56. 2017.

[24] SAÑUDO, C. Importancia de la Morfología y su valoración en los animales Domésticos. Valoración Morfológica de los Animales Domésticos. Ministerio de Medio Ambiente y Medio Rural y Marino Secretaría General Técnica Centro de Publicaciones (Ed.) Madrid. 863 pp. 2009

[25] STATISTICAL ANALYSIS SYSTEM INSTITUTE (SAS). Versión 9.0. User's guide: Statistics. Cary, NC. 2002.

[26] TIRIRA, D. Orden Rodentia: Roedores. Mamíferos del Ecuador: Guía de campo. Quito, Pichincha, Ecuador: Murciélago Blanco (Ed.) Pichincha. 576 pp. 2007.

[27] WRIGHT, S. An analysis of variability in number of digits in an inbred strain of guinea pigs. Genetics. 19: 506-536. 1934. 


\section{INSTRUCCIONES A LOS AUTORES}

La REVISTA CIENTÍFICA de la Facultad de Ciencias Veterinarias de la Universidad del Zulia es una revista internacional que recibe trabajos para publicación en las formas de artículos científicos originales no publicados, notas técnicas, cartas al editor y revisiones bibliográficas requeridas por el Comité Editorial. Como excepción a la condición de no publicado, podrán considerarse artículos que en forma completa o parcial hayan sido publicados en memorias de reuniones científicas de limitada circulación. Cualquier otra circunstancia debe ser explicada a la Oficina Editorial al momento del envío. Las cartas al editor deben contener comentarios útiles acerca de material publicado en la REVISTA CIENTÍFICA. La meta de publicar estas cartas es contribuir al intercambio constructivo de ideas y puntos de vista, con beneficios para la comunidad científica y para la REVISTA CIENTÍFICA. La aceptación de cartas al editor dependerá de la decisión del Comité Editorial. Para publicaciones como artículos científicos, notas técnicas y cartas al editor se aceptan como lenguajes tanto el español como el inglés.

Las revisiones bibliográficas serán escritas en el idioma inglés y no se aceptan más de dos autores, los cuales deben tener experiencia científica comprobada en el tópico propuesto. Sin embargo, trabajos extensos de edición para corregir lenguaje no se ofrece. Por tanto, los autores deben hacer revisar sus artículos por expertos con sólidos conocimientos de gramática sintaxis y estilo de la escritura científica.

El uso inapropiado del lenguaje puede conllevar al rechazo temporal de un artículo. Todos los artículos recibidos serán revisados en su forma y contenido por 3 expertos reconocidos usando el método del doble ciego.

Los artículos deben abordar aspectos relacionados a las áreas de la medicina veterinaria producción animal, economía agropecuaria, salud pública vinculada a las ciencias veterinarias (zoonosis), reproducción animal, tecnología de alimentos y vida silvestre. La aceptación de artículos que aborden cualquier otro tipo de tópicos relacionados será discutida por el Comité Editor. Aunque no de manera restringida, REVISTA CIENTÍFICA enfatiza en la publicación de información científica generada en zonas tropicales y subtropicales, o de aplicabilidad tropical.

El contenido de los artículos debe representar una contribución significativa al cuerpo del conocimiento científico y debe reunir además los requerimientos siguientes:

\section{Originales.}

Los artículos deben ser enviados con una carta de acuerdo entre los autores. En esta carta, el autor responsable y los co-autores deben declarar que el artículo enviado no ha sido publicado previamente, así como su aprobación con respecto a la forma y contenido. La firma de todos los autores debe ser incluida. Los manuscritos deben ser escritos en letra Arial, tamaño 12 ptos, a doble espacio y no más de 20 páginas, colocando en la primera página la información referente al titulo del trabajo (español, inglés), autores y la afiliación institucional, comenzando la segunda página con el resumen y abstract. Los cuatro márgenes serán de $2 \mathrm{~cm}$. Todas las páginas deben estar numeradas consecutivamente y los números de línea deben ser impresos en cada página (empezando con 1 en cada página) para mayo facilidad de referencia para los revisores. Se recomienda enviar el artículo al correo electrónico revistafcv@gmail.com en formato Word. Recomendamos usar “. Doc" en lugar de “. Docx", po posibles problemas de incompatibilidad. Las tablas, figuras y anexos deben incluirse dentro de documento, justamente después de ser citados en el texto. Los artículos deben ser inéditos y no haber sido enviados a otra revista.

Todos los trabajos aceptados pasan a ser propiedad de la REVISTA CIENTíFICA.

Los artículos deben contener: Título y resumen (español e inglés), introducción, materiales y métodos, resultados y discusión, conclusiones e implicaciones, agradecimiento y referencias bibliográficas.

2. Título.

El título debe describir la esencia del artículo de manera clara y concisa, debiendo aparecer en español e inglés. Debe incluirse un título corto para ser usado como tope de página.

\section{Autores.}

Todos los autores deben ser listados por su nombre completo en el orden respectivo (nombres y apellidos) dejando un espacio debajo del título. Si trae dos apellidos deben separase por un guion. El número de autores es ilimitado. Excepciones deben ser requeridas por escrito al Editor-Jefe por medio de una carta explicativa, especialmente cuando los autores pertenezcan a instituciones diferentes. La afiliación institucional de los autores debe ser señalada mediante numerales superíndices, y con un asterisco superíndice al autor para correspondencia. Seguido al asterisco superíndice, deberá indicarse teléfono, fax y/o direcció electrónica del autor para correspondencia. Así mismo, deben indicar la identificación ORCID de cada uno de los autores.

\section{Resumen.}

En español e inglés con un máximo de 300 palabras y comenzando en la segunda página del manuscrito. Para un apropiado uso del lenguaje y estilo, se recomienda consultar con un experto.

5. Palabras clave.

Estas son necesarias para la ubicación del trabajo en índices internacionales y bases de datos. Incluir un máximo de 5 , en español e inglés en el resumen y abstract, respectivamente. Deben estar separadas con punto y coma.

6. Tablas.

Deben citarse apropiadamente en el texto luego de ser nombradas, identificadas y enumeradas consecutivamente con números romanos. El encabezamiento debe ser conciso y descriptivo. Abreviaciones o símbolos deben ser explicadas al pie de la tabla. E encabezamiento debe ir sobre la tabla con la letra inicial en mayúsculas, en español o inglés, dependiendo del idioma en que el trabajo fue escrito; no ambos simultáneamente. No se aceptan fotocopias. Las tablas deben ser tan simples como sea posible y auto explicativas con el encabezamiento y notas al pie, permitiendo su comprensión sin necesidad de recurrir o referir el texto, no se aceptan referencias bibliográficas en las tablas.

\section{Figuras.}

Se puede incluir tanto fotografías como gráficos. Las figuras deben citarse apropiadamente en el texto inmediato a su señalamiento, identificadas y enumeradas consecutivamente usando números arábigos. El encabezamiento debe ser conciso y descriptivo, debiendo colocarse debajo de la figura con la letra inicial en mayúsculas, en español o inglés, dependiendo del idioma en que el trabajo fue escrito; no en ambos idiomas. No se aceptan fotocopias. Las fotografías deben ser identificadas en el reverso con un número y una flecha indicando la orientación correcta. En los casos de microfotografías, debe indicarse la magnificación usada.

\section{Conclusiones:}

Las mismas deben ser claras y precisas en ellas no se aceptan llamados a Referencias Biográficas.

\section{Agradecimiento:}

Sólo serán aceptadas agradecimientos institucionales.

\section{Referencias Bibliográficas.}

Deben presentarse en una lista numerada y en estricto orden alfabético. Deben ser citadas en el texto (en orden cronológico) usando números arábigos entre corchetes. Estos números deben parearse con los de la lista de referencias bibliográficas. No se aceptan como referencias trabajos no publicados, artículos de periódicos o revistas populares ni comunicaciones personales. Evite el uso excesivo de literatura no arbitrada (e.g., libros, manuales, referencias electrónicas en exceso, etc.). No deben citarse resúmenes, a menos que sean la única referencia en relación a un aspecto importante. Los autores son responsables del uso correcto presentación de las referencias.

No se permiten citas bibliográficas en el Resumen, abstract ni en Conclusiones, en Tablas y Figuras.

Los siguientes son ejemplos recomendados de como citar la bibliografía:

Revistas:

[1] MARQUEZ, E.J.; BARBOZA DE M., Y.; IZQUIERDO, P. Studies on the incorporation of bovine plasma in emulsion type of meat products. J. Food Sci. Tech. 34:337-339. 1997.

[2] ALVAREZ, R.; VACCARO, L.; VACCARO, R.; VERDE, O.; RIOS, L.; MEJIAS, H. Estimation of weights of dual purpose calves from body measurements. Rev. Científ. FCV-LUZ. IX (6): 502-507. 1999.

Libros:

Deben señalarse, después de los autores, el título del tema consultado en el texto (no capítulo), seguido de En: o In: (dependiendo del idioma) y título del libro (en renegrido). Luego, los nombres de los editores, si los hay, finalizando con (Ed. o Eds.).

[1] LEELAND, W.W. Steady state kinetics. In: The Enzymes. Boyer, P. (Ed.). 2nd Ed. Academic Press, New York. 66 pp. 1970.

[2] LOOSE-MITCHELL, D.S.; STANCEL, G.M. Estrogens and progestagens. In: The Pharmacological Basis of Therapeutics. Hardman, J.G., Limbird, L.E.; Goodman-Gilman, A. (Eds.). 10th Ed. McGraw Hill, New York, Pp 1613-1651. 2002.

Memorias:

Debe señalarse después del nombre del evento (en renegrido), el lugar, fecha de realización del mismo. Las páginas deben señalarse seguidas de pp.

[1] EDDI, C. Distomatosis, epidemiological and economic aspects of this zoonosis. Proc. Symposium on the Epidemiology of Foodborne Parasitic Zoonoses. P:A:H:O:/W:HO Latin American Congress of Parasitology. I Uruguayan Congress of Parasitology. Montevideo. 03/25-29. Uruguay: Pp 50-59 pp 1997.

[2] FARIA, M.H.; TONHATI, H.; NADER-FILHO, A.; DUARTE, J.M.C. Milk production and some constituents in two buffalo herds in São Paulo State, Brazil. Proceeding 5th World Buffalo Congress. Caserta, 10/13-16. Pp 30-38. 1997.

\section{Referencias electrónicas:}

No se aceptan referencias electrónicas a menos que sean trabajos arbitrados, boletines o comunicaciones respaldadas por instituciones científicas. Evite el uso excesivo de este tipo de referencias. En tales casos, estas referencias deben incluir: autor(es), título del trabajo, y el año del trabajo. Institución(es) que la respaldan. Luego se coloca: En Línea: On Line: (dependiendo del idioma), seguido de la página web consultada, y finalmente, la fecha de consulta. Ejemplo:

[1] FERNÁNDEZ, M.A. Manejo de la calidad de la dieta. 2005. La Mañana (Suplemento) nstituto Nacional de Tecnología Agropecuaria (INTA). Argentina. En Línea: http://www. lamañana.com.ar/html. 01/12/05

MUY IMPORTANTE: Cuando un trabajo sea devuelto a la Revista previamente corregido por los autores, no podrá ser sometido a corrección posterior a su publicación. 


\section{GUIDE FOR AUTHORS}

The REVISTA CIENTÍFICA from the Faculty of Veterinary Medicine, Universidad del Zulia is an international journal that receives submissions for publication in the form of original and unpublished manuscripts, technical notes, letters to the editor, and those review articles requested by the Editorial Board. Exceptions to the unpublished condition include the complete or partial publication in scientific meeting proceedings with limited circulation. Any othe circumstance should be explained to the Editorial office at the moment of submission. The letters to the editor must contain useful comments on material published in the journal. It is the goal that publication of such letters may contribute to a constructive exchange of views with benefits to both the scientific community and the journal. Acceptance of submitted letters will depend upon decision of the Editorial.

For publications such as scientific papers, technical notes and letters to the editor are accepted as both languages Spanish and English. Literature reviews will be written in English and no more than two authors are accepted, whose must have scientific expertise in the proposed topic. Extensive editing to correct language is not available. Hence, authors should have their manuscripts reviewed by experts with solid knowledge on spelling, grammar, syntax and scientific writing style. Misused and inappropriate language may lead to temporal rejection of a manuscript. All submissions will be reviewed in their form and content by 3 recognized experts using the method of double blind.

Manuscripts must deal with aspects related to the fields of veterinary clinical sciences, animal production, agricultural economic, public health related to veterinary sciences, animal reproduction, food technology related to animal products and wild life. Acceptance of manuscripts dealing with any other type of related topics will be discussed by the Editorial Board. Although not restricted to, REVISTA CIENTIFICA emphasizes on publishing scientific information generated from tropical and subtropical zones or with tropical applicability. The content of manuscripts should add significant contribution to the body of scientific knowledge and must meet the following requirements:

\section{Originals.}

Manuscripts should be submitted together with an author agreement letter. In such letter, the responsible author and co-authors should declare the unpublished condition of the material and their agreement on the form and content of the manuscript. Signatures of all, the responsible author and co-authors should be included. Manuscripts should be written in Arial, 12-point font, with 2.0 spaced and not more than 20 pages, It should be sent by email to revistafcv@gmail. com, placing on the first page the information about the title of the work (Spanish, English), authors and institutional affiliation, starting second page with abstract. The four margins will be $2.0 \mathrm{~cm}$. All pages should be numbered consecutively, and line numbers should be printed on each page (starting with 1 on each page) to facilitate ease of reference for the reviewers. In Word format as a unique file; we encourage to use .doc files. Tables, figures and appendice should be included into the same Word document,. Manuscripts should be in edit and not sent to any other journal.

\section{All accepted manuscripts become property of REVISTA CIENTIFICA.}

Manuscripts must contain: Title, abstract (English-Spanish), introduction, materials and methods, results and discussion, conclusions and implications, acknowledgement, and bibliographic references.

\section{Title.}

The title should describe the essence of the manuscript in a very clear and concise manner. It should appear in both, English and Spanish. A short title to be used as a head page running title should be also included.

\section{Authors.}

Leaving a space below the title, all authors must be listed with full names in the respective order (first names and last names). List of authors is unlimited. Use superscript numbers to match institutional affiliation of authors and a superscript asterisk to identify the corresponding author. Matching the superscript numbers, the institutional affiliation and current address of all authors should be provided. Likewise, matching the asterisk symbol, telephone and fax numbers and e-mail address of the corresponding author should be included. ORCID ID is necesary for all authors.

4. Abstract.

In Spanish and English with a maximum of 300 words and starting on the second page of the manuscript. For an appropriate use of language and style, it is recommended to consult with an expert. Bibliographic references are not accepted.

5. Key words.

These are necessary for placement in international indexes and databases. Maximum of 5 , in English and Spanish accordingly with abstracts, separated with dot and semicolon.

\section{Tables.}

These should be appropriately cited in the text and must be identified and consecutively numbered using Roman numerals. A concise and descriptive heading is requested. Abbreviation or symbols should be explained in a caption below the table. Title must be above the table with the first initial in capital letters. Title should be presented in both, in Spanish or English, depending of the language in which the work was written, no simultaneously. Xerox copies will not be accepted Keep tables as simple as possible. Tables are self-contained with the title and footnotes providing all information to understand the table without referring the text separated with semicolon. Tables should be included in the text immediately after mentioning them.

\section{Figures.}

These include both photographs and graphs. Figures should be appropriately cited in the text and identified and consecutively numbered using Arabic numerals. A concise and descriptive heading is requested. Title must be above the table with the first initial in capital letters. Title should be presented in both, in Spanish or English, depending of the language in which the work was written, no simultaneously. Xerox copies will not be accepted. Photographs should be identified on the back by number and an arrow indicating the correct orientation. When a microphotograph is used, the magnification used should be indicated. Photographs and Figures should be included in the text immediately after mentioned.

\section{Acknowledgment:}

Only institutional acknowledgments are allowed.

9. Conclusions:

Clear and precise. Bibliographic references are not acepted.

\section{Bibliographic references:}

These must be presented in a numbered list organized in a strict alphabetical order. References should be cited in the text in chronological order, using Arabic numbers between brackets. These numbers should be matched with the ones on the bibliographical references list. Unpublished works, newspaper or popular magazines articles, and personal communications are not accepted as references. Avoid the excessive use of non-peer reviewed material (e.g., books, handbooks). Abstract should not be cited unless it is the only available reference to an important concept. Authors are responsible for the correct use and presentation of Bibliographic cites, are not permitted in Abstract, Conclusions, Tables and Figures.

The following are recommended examples:

Journals:

[1] MARQUEZ, E.J.; BARBOZA DE M., Y.; IZQUIERDO, P. Studies on the incorporation of bovine plasma in emulsion type of meat products. J. Food Sci. Tech. 34:337-339. 1997

[2] ALVAREZ, R.; VACCARO, L.; VACCARO, R.; VERDE, O.; RIOS, L.; MEJIAS, H. Estimation of weights of dual purpose calves from body measurements. Rev. Científ. FCV-LUZ. IX (6): 502-507. 1999.

Books:

After the authors should be included title of the consulted topic or theme in the book (no chapter) followed by In: and title of the book (in black letters). After that, the names of the Editors, if there are, followed by (Ed. or Eds.).

[1] LEELAND, W.W. Steady state kinetics. In: The Enzymes. Boyer, P. (Ed.). 2nd Ed. Academic Press, New York. 66 pp. 1970.

[2] LOOSE-MITCHELL, D.S.; STANCEL, G.M. Estrogens and progestagens. In: The Pharmacological Basis of Therapeutics. Hardman, J.G., Limbird, L.E.; Goodman-Gilman, A. (Eds.). 10th Ed. McGraw Hill, New York, Pp 1613-1651. 2002

\section{Proceedings:}

After the event name (in black letters) should be included the place, date and country of the event. The pages should be finalized with "pp for total pages or Pp for consulted pages.

[1] EDDI, C. Distomatosis, epidemiological and economic aspects of this zoonosis. Proc. Symposium on the Epidemiology of Foodborne Parasitic Zoonoses. P:A:H:O:/W:HO Latin American Congress of Parasitology. I Uruguayan Congress of Parasitology. Montevideo. 03/25-29. Uruguay: Pp 50-59. 1997.

[2] FARIA, M.H.; TONHATI, H.; NADER-FILHO, A.; DUARTE, J.M.C. Milk production and some constituents in two buffalo herds in São Paulo State, Brazil. Proceeding 5th World Buffalo Congress. Caserta, 10/13-16. Italy. 140 pp 1997.

\section{Electronic references:}

Electronic references are not accepted unless these are peer reviewed manuscripts, bulletins or communications supported by scientific institutions. Avoid the excessive use of this type of references. For such cases, the on-line references must include: authors, title of the work, year of the work, institution that support the work. Later On Line: not under line followed by the consulted web and the complete consult date.

[1] FERNÁNDEZ, M. A. Manejo de la calidad de la dieta. 2005. La Mañana (Suplemento) Instituto Nacional de Tecnología Agropecuaria (INTA). Argentina. En Línea: http://www. lamañana.com.ar/html. 01/12/05

VERY IMPORTANT: When a manuscrit is returned to the Journal, previously corrected by the authors, it won`t beable to be subjected to later corrections after publishing 


\section{UNIVERSIDAD DEL ZULIA \\ REVISTA CIENTÍFICA \\ FACULTAD DE CIENCIAS VETERINARIAS \\ DIVISIÓN DE INVESTIGACIÓN}

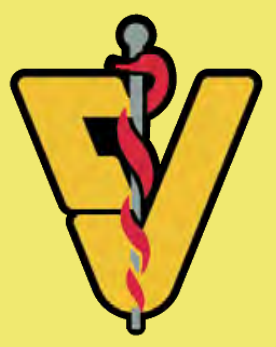

Estimado colega,

La Revista Científica (RCV) está aceptando artículos científicos para su publicación. La RCV publica artículos solicitados y no solicitados de alta calidad, en español e inglés, en todas las áreas de las Ciencias Veterinarias. Todos los artículos publicados en RCV serán revisados por árbitros cualificados.

Nuestro objetivo es informar a los autores de la decisión sobre su manuscrito en unplazo de ocho semanas desde su entrega. Tras la aceptación de su artículo, el mismo será publicado en el número inmediatamente disponible.

Una de las herramientas claves para los investigadores a nivel mundial, es poder disponer de libre acceso a las publicaciones. Y dado que la Revista Científica de Veterinaria está plenamente comprometida con este objetivo, la misma posee el libre acceso a todos los artículos tan pronto como se publiquen y en su base de datos se encuentra desde el primer número editado en 1991.

Es así que en nombre del comité editor, le solicito su apoyo para que esta iniciativa continúe, mediante la publicación de sus documentos en esta revista.

Las instrucciones para autores yo tras informaciones adicionales pueden ser consultadas en nuestra página https://produccioncientificaluz. org/index.php/cientifica/instrucciones.

Aquellos autores interesados en publicar deberán enviar su manuscrito(s) al correo electrónico: revistafcv@gmail.com o revista@fcv. luz.edu.ve.

Saludos cordiales,

\section{Dr. Mario Pérez Barrientos}

Editor Jefe

Revista Científica de Veterinaria 


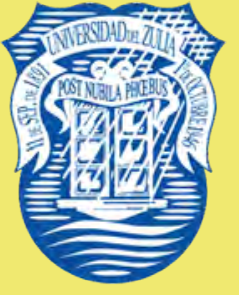

\section{UNIVERSIDAD DEL ZULIA \\ REVISTA CIENTÍFICA \\ FACULTAD DE CIENCIAS VETERINARIAS \\ DIVISIÓN DE INVESTIGACIÓN}

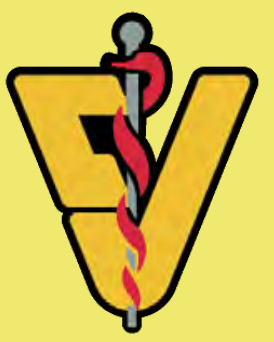

Dear Colleague,

The Revista Cientifica (RCV) is currently accepting manuscripts for publication. RCV publishes high-quality solicited and unsolicited articles, in Spanish and English, in all areas of Veterinary Science. All articles published in RCV will be peer-reviewed.

Our objective is to inform authors of the decision on their manuscript within eigth weeks of submission. Following acceptance, a paper will normally be published in the next avaliable issue.

One key request of researchers across the world is open access to research publications. Revista Científica Veterinaria is fully committed to providing free access to all articles as soon as they are published. We ask you to support this initiative by publishing your papers in the journal.

Instruction for authors and other details are avaliable on our website https://produccioncientificaluz.org/index.php/cientifica/instrucciones.

Prospective authors should send their manuscript(s) revistafcv@gmail.com or revista@fcv.luz.edu.ve

Best regards,

\section{Dr. Mario Pérez Barrientos}

Chif Editor

Revista Científica de Veterinaria 

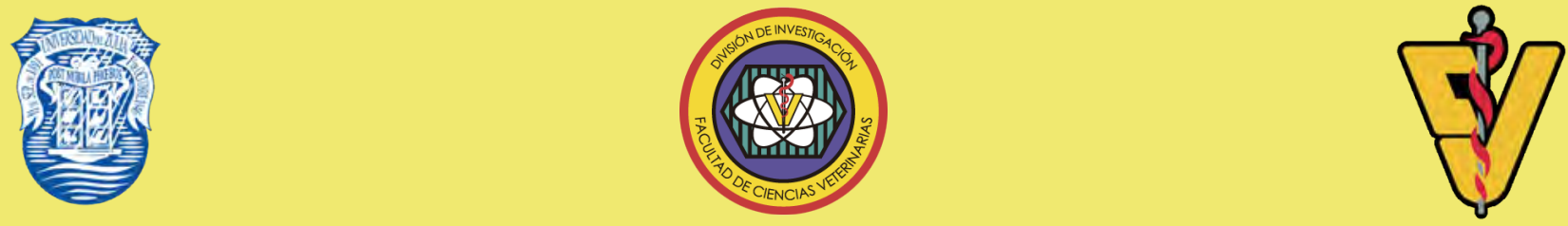

\section{UNIVERSIDAD DEL ZULIA REVISTA CIENTÍFICA \\ FACULTAD DE CIENCIAS VETERINARIAS DIVISIÓN DE INVESTIGACIÓN \\ Vol. XXXI (2) 2021}

ÍNDICE

Pag.

EDITORIAL

Salud Pública Veterinaria

Detección de anticuerpos de Brucella spp. en mataderos del estado Bolívar y Soledad, municipio Independencia, estado Anzoátegui, Venezuela, 2006

\section{Producción Animal}

Desempeño en la ceba a pastoreo y rasgos de la canal de toros implantados y suplementados

Comportamiento animal y composición botánica de la dieta de ovinos apacentando estrella africana (Cynodon plectostachyus (L.) Pers.) en monocultivo y asociada con Leucaena leucocephala (Lam.) de Wit. y Guazuma ulmifolia (Lam.)

Morfometria y faneroptica de subpoblaciones de cobayos (Cavia porcellus) nativos del altiplano sur ecuatoriano

INDEX

EDITORIAL

\section{Veterinary Public Health}

Screening of antibodies to Brucella spp. in slaughterhouses of the Bolívar state and Soledad, Independencia municipality, Anzoategui state, Venezuela, 2006

\section{Animal Production}

Fattening performance and carcass traits of implanted and supplemented grassfed bulls

Animal behavior and botanical composition of the diet of the african ovine star (Cynodon plectostachyus (L) Pers.) in monoculture and associated with Leucaena leucocephala (Lam.) de Wit. and Guazuma ulmifolia (Lam.)

Morphometric and faneroptic characterization of sub populations native cobayos (Cavia porcellus) of the south equatorian highland 